UNIVERSIDADE DE SÃO PAULO

FACULDADE DE ECONOMIA, ADMINISTRAÇÃO E CONTABILIDADE DE RIBEIRÃO PRETO

DEPARTAMENTO DE CONTABILIDADE

PROGRAMA DE PÓS-GRADUAÇÃO EM CONTROLADORIA E

CONTABILIDADE

ANDRÉ PRECINOTTO

Transparência de dispensas de licitação em situações de emergência nacional

ORIENTADOR: PROF. DR. ANDRÉ CARLOS BUSANELLI DE AQUINO COORIENTADORA: PROFA. DRA. LIDIANE NAZARÉ DA SILVA DIAS

RIBEIRÃO PRETO 
Prof. Dr. Vahan Agopyan

Reitor da Universidade de São Paulo

Prof. Dr. André Lucirton Costa

Diretor da Faculdade de Economia, Administração e Contabilidade de Ribeirão Preto

Prof. Dr. Marcelo Botelho da Costa Moraes

Coordenador do Programa de Pós-Graduação em Controladoria e Contabilidade

Profa. Dra. Adriana Maria Procópio de Araújo

Chefe do Departamento de Contabilidade 


\section{ANDRÉ PRECINOTTO}

Transparência de dispensas de licitação em situações de emergência nacional

Dissertação apresentada ao Programa de PósGraduação em Controladoria e Contabilidade da Faculdade de Economia, Administração e Contabilidade de Ribeirão Preto da Universidade de São Paulo para obtenção do título de Mestre em Ciências. Versão corrigida. A versão original encontra-se disponível no Serviço de PósGraduação da FEA - RP / USP.

ORIENTADOR: PROF. DR. ANDRÉ CARLOS BUSANELLI DE AQUINO

COORIENTADORA: PROFA. DRA. LIDIANE NAZARÉ DA SILVA DIAS

RIBEIRÃO PRETO 
Autorizo a reprodução e divulgação total ou parcial deste trabalho, por qualquer meio convencional ou eletrônico, para fins de estudo e pesquisa, desde que citada a fonte.

FICHA CATALOGRÁFICA

Precinotto, André

Transparência de dispensas de licitação em situações de emergência nacional. Ribeirão Preto, 2021.

$121 \mathrm{p}$.

Dissertação (Mestrado), apresentada à Faculdade de Economia, Administração e Contabilidade de Ribeirão Preto/USP. Área de concentração: Controladoria e Contabilidade.

Orientador: Aquino, André Carlos Busanelli de Coorientadora: Dias, Lidiane Nazaré da Silva

1. Open government; Paradoxos. 2. Terceirização. 3. Dispensa de licitação. 4. Governos locais. 5. Pandemia 
Nome: Precinotto, André

Título: Transparência de dispensas de licitação em situações de emergência nacional

Dissertação apresentada ao Programa de Pós-Graduação em Controladoria e Contabilidade da Faculdade de Economia, Administração e Contabilidade de Ribeirão Preto da Universidade de São Paulo, como requisito para obtenção do título de Mestre em Ciências.

Aprovado em:

\section{Banca Examinadora}

Prof. Dr. Instituição:

Julgamento: Assinatura:

Prof. Dr. Instituição:

Julgamento: Assinatura:

Prof. Dr. Instituição:

Julgamento: Assinatura:

Prof. Dr. Instituição:

Julgamento: Assinatura: 
Dedico este trabalho aos meus pais Hilda Maria e José Mário e ao meu irmão Mateus. Meus heróis! 


\section{AGRADECIMENTOS}

Em primeiro lugar agradeço a Deus por tudo!

Aos meus pais Hilda Maria e José Mário e ao meu irmão Mateus. Vocês são TUDO na minha vida! Ao meu orientador Prof. Dr. André Carlos Busanelli de Aquino por ter acreditado em mim e pelos ensinamentos que proporcionaram a realização de um sonho. É uma honra e um privilégio ter trabalhado ao seu lado. À minha coorientadora Profa. Dra. Lidiane Nazaré da Silva Dias pelos incentivos e por ter compartilhado sua experiência e conhecimento.

Aos membros do grupo de pesquisa Public Sector Accounting \& Governance in Brazil pelas contribuições que fortaleceram os resultados deste trabalho.

Aos Professores Doutores, Marcelo Sanches Pagliarussi, Amaury José Rezende, Carlos Alberto Grespan Bonacim e José Dutra de Oliveira Neto pelas aulas inesquecíveis.

A todos os outros Professores que já passaram pela minha vida. Vocês também fazem parte dessa conquista.

A todos os meus familiares. Sem vocês, essa conquista seria muito mais difícil.

Aos entrevistados da pesquisa, pela paciência, compreensão e contribuição.

A todos os funcionários da USP.

A todos os meus amigos de infância e de trabalho.

Ao Presidente da Câmara Municipal de Guaíra, José Reginaldo Moretti pela confiança. A todos os outros que de uma forma ou de outra contribuíram e seguiram junto comigo nessa caminhada que foi o maior desafio da minha vida.

Pedi e se vos dará. Buscai e achareis. Batei e vos será aberto. Mateus 7, 7. 


\section{RESUMO}

Precinotto, André. Transparência de dispensas de licitação em situações de emergência nacional Dissertação (Mestrado em Controladoria e Contabilidade) - Faculdade de Economia, Administração e Contabilidade de Ribeirão Preto. Universidade de São Paulo, Ribeirão Preto, 2021.

O presente estudo discutiu a publicização dos serviços terceirizados por prefeituras municipais e observou tensões, contradições e dilemas que surgiram na contratação de serviços públicos quando o contexto foi alterado com o início da pandemia da Covid-19. A pesquisa compara como o início de estados de emergência/calamidade afetam a transparência das dispensas de licitações durante a pandemia da Covid-19 em municípios do Estado de São Paulo. O estudo agrega à literatura de abertura de governos com a discussão de como as contradições e dilemas entre a multiplicidade de stakeholders (indivíduos e organizações) afetam a transparência de órgãos públicos. Foi realizada uma análise comparada com 32 municípios do Estado de São Paulo, a partir de análise de conteúdo de documentos e entrevistas com diversos interessados na transparência pública como, contadores, membros de organizações sociais, sindicalistas e jornalistas. A análise das dispensas de licitações constatou que em geral a divulgação completa dos documentos destas contratações diminuiu durante a pandemia em 2020. Durante a pandemia, a divulgação de informações como boletins da Covid-19 e agenda de vacinações foi intensa em alguns municípios, mas a transparência das contratações diminuiu com as dispensas de licitações. A redução pode ser um efeito das tensões existentes entre o pólo do paradoxo (opacidade) que exerce pressão para ocultar as informações e o pólo que exige a divulgação dos dados públicos (transparência).

Palavras chave: Open government; Paradoxos; Terceirização; Dispensa de licitação; Governos locais; Pandemia 


\begin{abstract}
Precinotto, André. Transparency on public procurement in a national emergency context. Dissertation (Master's degree on Accounting and Controllership) - Faculty of Economics, Business Administration and Accounting. University of São Paulo, Ribeirão Preto, 2021.

This study discussed the publicization of outsourced services by city halls from Brazilian municipalities and observed the tensions, contradictions and dilemmas that emerged in procurement of service delivery as the context changed due to pandemic context. The study compared the effects of states of emergency/calamity on the transparency of bidding waivers during the covid-19 pandemic in the state of São Paulo. We aggregate to the literature on open government bringing to the discussion on how the contradictions and dilemmas faced by multiple stakeholders (individuals and organizations) affect the transparency of public sector organizations. We run a comparative analysis with 32 municipalities from São Paulo state in Brazil based on content analysis of procurement documents and interviews with members of social organizations, trade unionists and journalists. The analysis of bidding waivers found that overall full disclosure of documents from these contracts decreased during the pandemic in 2020. During the pandemic context ne observed the dissemination of information such as covid bulletins, vaccination schedules, however the analyzed cases showed-up reduction of transparency of service procurement. The reduction may be an effect of the existing tensions between the pole of paradox (opacity) that exerts pressure to hide information and the pole that requires the disclosure of public data (transparency).
\end{abstract}

Keywords: Open government; Paradoxes; Outsourcing; Bidding waiver; Local governments; Pandemic 


\section{SUMÁRIO}

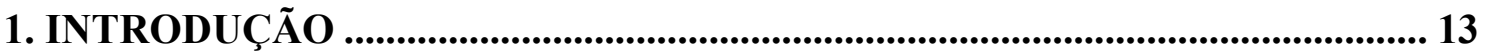

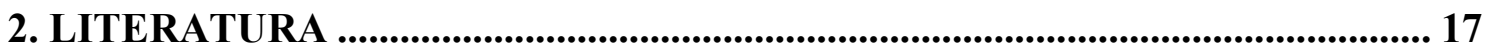

2.1 Publicização de dados e governo aberto ………………………………………..... 17

2.2 Transparência fiscal no Brasil ...................................................................... 21

2.3 Teoria de Paradoxos em organizações ............................................................... 24

2.3.1 Estudos empíricos na teoria do paradoxo ...................................................... 26

3. TERCEIRIZAÇÃO E TRANSPARÊNCIA PRÉ E PÓS PANDEMIA ................ 32

3.1 Ampliação da terceirização da mão de obra ………………………………….... 32

3.2 O posicionamento dos órgãos fiscalizadores e sindicatos.................................... 34

3.3 Corrupção em serviços terceirizados ............................................................... 35

3.4 Contratações durante o regime de exceção da pandemia COVID-19............. 36

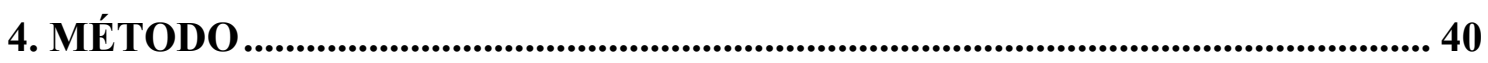

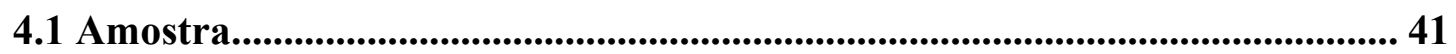

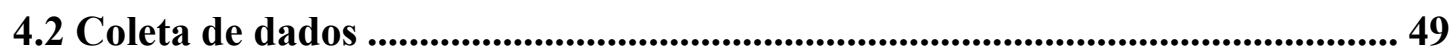

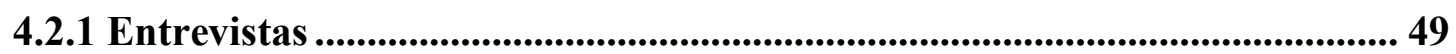

4.2.2 Atos de contratação e seus documentos ............................................................. 53

4.2.3 Período da pandemia de março de 2020 a dezembro de 2020 ....................... 54

4.2.4 Período pré-pandemia de março a dezembro de 2019 .................................... 54

4.3 Tratamento dos dados e evidências........................................................................ 55

5. CONTRATAÇÃO, PUBLICIZAÇÃO E PANDEMIA.......................................57

5.1 Estágios, fases da licitação e a publicização de documentos.................................. 57

5.2 Regime de exceção nas contratações........................................................................ 60

6. ANÁLISE DA PUBLICIZAÇÃO DURANTE A PANDEMIA.............................6 63

7. PARADOXO SOBRE ABERTURA DE GOVERNOS E O EFEITO DA

PANDEMIA ............................................................................................................ 67

7.1 Entendimento da transparência antes e durante a pandemia ............................... 68

7.2 Justificativas para opacidade: Cultura e Capacidade Estatal............................... 72

7.3 Como a pandemia afeta o equilíbrio então vigente ................................................ 75

8. CONCLUSÃO E IMPLICAÇÕES ...................................................................... 80

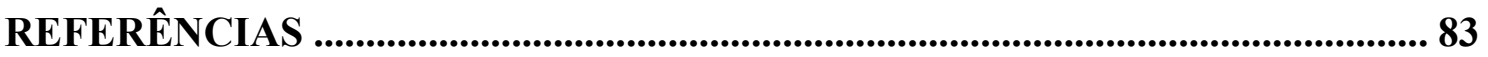

APÊNDICE A - Estudos empíricos open government e transparência..................... 100

APÊNDICE B - Estudos empíricos paradoxo ......................................................... 104

APÊNDICE C - Levantamento de documentos ..................................................... 114

APÊNDICE D - Descrição da base de atos de contratação ........................................ 120 


\section{LISTA DE TABELAS}

Tabela 1. Municípios da amostra acompanhados durante a pandemia COVID-19 entre $11 / 03 / 2020$ a $31 / 12 / 2020$ 45

Tabela 2. Determinação pelo Governo do Estado de São Paulo pelo Plano São Paulo. 48

Tabela 3. Respondentes acessados 51

Tabela 4. Contratação e publicização em regime de normalidade vs. regime de exceção 61

Tabela 5. Média de divulgação dos atos, antes e durante a pandemia 63

Tabela 6. Queda ou aumento da divulgação por objeto de contrato. 65

Tabela 7. Tipos, Finalidades e Quantidade dos Atos entre (11/03/2020 a 31/12/2020 início e decorrer da pandemia até o final de 2020)

Tabela 8. Dispensas de licitação identificados 2020-2021 120

Tabela 9. Média de divulgação das dispensas de licitações por canal, antes e durante a pandemia..... 


\section{LISTA DE FIGURAS}

Figura 1. Distribuição dos casos no estado de São Paulo. 43

Figura 2. Fluxograma da coleta de documentos e entrevistas 52

Figura 3. Fonte de Consulta - Portais de transparência dos casos estudados 115

Figura 4. Fases do processo de contratação 116

Figura 5. Interessados nos documentos. 117 


\section{INTRODUÇÃO}

Paradoxo diz respeito a elementos, que ao mesmo tempo são contraditórios, mas inter-relacionados (Lewis, 2000) e com características mutuamente excludentes (Berti \& Simpson, 2019). Além disso, paradoxos se manifestam em organizações na forma de tensões, contradições e dilemas (Putnam, Fairhurst, \& Banghart, 2016). Em complemento a tal afirmação, Jarzabkowski, Lê e Van de Ven (2013), relatam que vários paradoxos são encontrados em nível organizacional e individual.

O processo de abertura de governos é resultado de pressões externas (Wong \& Welch, 2004). As tensões dessa abertura ocorrem quando as entidades governamentais evitam correr riscos na divulgação de informações (Bannister \& Connolly, 2011) e os demais interessados (cidadãos, empresas, outras agências governamentais, organizações sem fins lucrativos, pesquisadores) exigem a disponibilização de dados dos governos (Rowley, 2011).

Para atender as demandas das partes interessadas, o governo precisa decidir sobre o conteúdo que será divulgado em seus websites (Mahler \& Regan, 2006). Tal decisão pode ser influenciada pela missão, valores, cultura organizacional, contexto político ou por opiniões de agentes internos da organização (Mahler \& Regan, 2006). Além disso, a publicização de informações públicas é complexa e dinâmica em razão da constante evolução tecnológica e das interações entre governo e stakeholders (Meijer, 2013).

No Brasil, parte da literatura que trata de abertura de governos analisou o grau de atendimento da legislação relacionada à transparência ativa e passiva e constatou que tais normas são atendidas parcialmente (Leite Filho, Colares, \& Andrade, 2015; Cruz, M., Silva, \& Spinelli, 2016; Michener, Contreras, \& Niskier, 2018; Antunes, 2018).

Outros estudos, apontaram as barreiras que dificultam o desenvolvimento da transparência (Luciano, Wiedenhöft, \& Santos, 2018) e identificaram mecanismos, como dados completos, acessíveis, oportunos que aumentam a transparência de forma a atender as demandas de usuários de informações governamentais (Klein, Klein, \& Luciano, 2018).

Ao mesmo tempo, a literatura internacional sobre paradoxos destaca a relevância de discutir a multiplicidade de interessados porque as relações entre organizações e indivíduos geram elementos paradoxais (tensões, contradições e dilemas). Tal literatura, discute por exemplo, conflitos entre lógicas de serviços públicos e privados (Jay, 2013), 
cooperação entre concorrentes ou concorrência entre parcerias (Raza-Ullah, Bengtsson, \& Kock, 2014), objetivo em comum com opções de resoluções antagônicas (Huq, Reay, \& Chreim, 2017). Outras pesquisas sobre paradoxos também indicam que a implantação de normas ou o uso tecnologia da informação podem contribuir para criação de tensões e contradições entre indivíduos e organizações (Jarzabkowski et al. 2013; Adu, 2018; Drummond, 2008).

As tensões também são observadas num cenário onde ocorre um aumento da terceirização dos serviços públicos (Alves, 2019). Além disso, os serviços públicos terceirizados propiciam o surgimento de questões relacionadas ao limite de gastos com pessoal (Di Pietro, 2009) e escândalos de corrupção (Campos, 2019; Freitas, 2015; Grizotti, 2015). Uma pesquisa realizada pela Confederação Nacional dos Municípios (CNM) apontou que a terceirização de serviços públicos é justificada para que os gastos com pessoal estejam dentro dos limites exigidos pela legislação. Tais fatos demostram que, a publicização da terceirização de serviços pode impactar os gastos com pessoal porque outros interessados em informações públicas podem pressionar pelo equilíbrio das contas governamentais. Além disso, a divulgação de serviços públicos terceirizados pode gerar tensões entre diversos stakeholders como: o próprio governo, servidores públicos, sindicatos, órgãos fiscalizadores, empresas prestadoras de serviços e a população.

A pandemia do novo coronavírus (Sars-Cov-2) causador da doença Covid-19 provocou mudanças nas relações entre os indivíduos e nas organizações (Lopes \& Santos, 2020). Tal fenômeno fez com que os diversos interessados na abertura de governos cumprissem medidas de combate à pandemia (Lyrio, Santos, Rosa, \& Ferreira, 2020). De certa forma, a pandemia também fez com que a situação de calamidade pública flexibilizasse as contratações por meio das dispensas de licitações (Maia, Costa, Santos, Nascimento, \& Melo, 2020). Além disso, a situação de calamidade causada pela pandemia pode agravar práticas corruptas (Costa, 2020). Tais práticas corruptas podem estar presentes em órgãos responsáveis por fiscalizar barragens de mineradoras como aquelas que foram rompidas nos municípios de Mariana-MG e Brumadinho-MG (Passarinho, 2019).

As questões que envolvem a abertura de governos compreendem vários contextos os quais precisam ser explorados para que se obtenha um entendimento de como tal fenômeno surge e se desenvolve (Pozen, 2020). Para a compreensão destas questões, é preciso considerar que as políticas de transparência podem, ao mesmo tempo, trazer 
benefícios e malefícios para os diversos interessados neste tema (Pozen, 2020). Os benefícios trazidos pelas políticas transparência estão relacionados à eficiência e eficácia dos governos (Kornberger et al., 2017), enquanto que os malefícios podem lesar a reputação dos governos (Bannister \& Connolly, 2011). Além disso, a abordagem de assuntos como dinâmica de poder e influências organizacionais internas e externas podem contribuir para literatura de open government (Pozen, 2020).

A análise da literatura sobre abertura de governos no Brasil indica que é preciso explorar os paradoxos, as tensões e contradições entre a diversidade de stakeholders envolvidos neste fenômeno. Tal afirmação é reforçada por Klein, Klein, \& Luciano (2018) e Luciano, Wiedenhöft, \& Santos (2018), que sugerem aprofundar o conhecimento em questões sobre as barreiras, tensões e stakeholders associados à transparência governamental. Assim, o presente estudo pretende: (i) discutir a publicização dos serviços terceirizados em governos locais (prefeituras) para tratar de tensões, contradições e dilemas em ambientes organizacionais (Smith \& Lewis, 2011; Schad, Lewis, Raisch, \& Smith, 2016); (ii) comparar os efeitos dos estados de emergência/calamidade decretados por prefeitos durante a pandemia da Covid-19 no Estado de São Paulo.

A mudança de contexto de forma repentina, como crises, calamidades nacionais como a pandemia em curso, abre espaço para legitimar regimes de exceção na contratação, altera as tensões do paradoxo existente e afeta o equilíbrio de questões como transparência $v$ s. opacidade de divulgação de contratos, salários, indicadores fiscais. A ideia implícita na pesquisa é de que o nível de transparência de governos não é algo dado por contingências estáticas, como características demográficas ou sociais (como IDH, PIB) ou recursos materiais ou humanos na prefeitura, mas por um tênue equilíbrio entre diversas pressões que podem mudar conforme o contexto altera a forma como os principais stakeholders interagem com o novo contexto.

A pesquisa selecionou 32 municípios paulistas para serem observados antes e durante o primeiro ano da pandemia em curso. Esses municípios haviam sido já avaliados pela Controladoria Geral da União (CGU) entre os anos de 2015 a 2017 em termos de transparência de seus portais. A pesquisa também observou as dispensas de licitações em portais de transparência e diários oficiais eletrônicos entre março e dezembro de 2019 e março e dezembro de 2020. Foram em seguida realizadas entrevistas com profissionais responsáveis pela publicização de portais de transparência como contadores públicos. Adicionalmente, foram entrevistados os demais stakeholders envolvidos como 
jornalistas, sindicalistas, presidentes de câmaras municipais e membros de organizações sociais.

A observação das dispensas de licitações comparou seus dados básicos e a divulgação completa destes processos de compras, ou seja, se os seus respectivos contratos eram disponibilizados na íntegra. A pesquisa constatou que houve uma redução da divulgação completa das dispensas de licitações durante a pandemia. A análise das entrevistas complementou a análise dos documentos ao revelar que em alguns casos ocorreram aumento de contratações por meio de processos poucos transparentes, as dispensas de licitações. Além disso, a análise das entrevistas também mostrou como os diversos interessados em informações públicas gerenciam as tensões e pressões sofridas e exercidas entre eles antes e durante a pandemia.

Esta pesquisa contribui para a literatura de paradoxos organizacionais ao explorar e discutir os paradoxos presentes em questões associadas à abertura de governos em momentos críticos como a pandemia da Covid-19. Além disso, este estudo também poderá contribuir aos profissionais da área de forma a indicar como os paradoxos podem ser gerenciados ou reduzidos.

A dissertação está organizada da seguinte forma. Primeiro, há a apresentação das literaturas que trazem a discussão teórica e empírica de open government e paradoxo, respectivamente. Em seguida, a contextualização do tema mostra o desenvolvimento das normas, as questões que envolvem os stakeholders na terceirização dos serviços públicos e a inserção da pandemia nestes assuntos. Posteriormente, a seção de método detalha os procedimentos adotados na definição da amostra e na coleta de dados. Na sequência, são expostos aspectos sobre processos de contratação, publicização e o regime de exceção em contratações provocado pela pandemia. No tópico seguinte são apresentadas as análises dos documentos e entrevistas. Finalmente, são destacadas as discussões, implicações e as conclusões. 


\section{LITERATURA}

\subsection{Publicização de dados e governo aberto}

Antes de apresentar a literatura sobre publicização de dados e governo aberto (Apêndice A) é importante esclarecer a definição destes dois conceitos porque eles podem ser confundidos ou mal interpretados (Sandoval-Almazán, 2015). Governo aberto é um processo de abertura, com suporte tecnológico, que permite ao cidadão a utilização de informações públicas, a participação em tomada de decisões e a colaboração na melhoria de serviços públicos (Sandoval-Almazán, 2015). A publicização de dados que também pode ser entendida como transparência é um ato resultante da abertura que torna transparente os dados públicos e que ainda faz parte de um sistema composto pela participação e colaboração (Sandoval-Almazán, 2015).

McDermott (2010), reforça essas ideias ao afirmar que o processo de abertura de governos pode ocorrer nas seguintes dimensões: transparência (publicização de dados e/ou informações); participação (envolvimento da sociedade) e colaboração (cooperação entre entidades governamentais e não governamentais). Grimmelikhuijsen \& Feeney (2017), mencionam ainda que a acessibilidade (capacidade de stakeholders utilizarem dados e/ou informações) também é uma dimensão do processo de abertura de governos.

Tal processo tem forte conexão com a tecnologia (Sandoval-Almazán \& GilGarcia, 2012) que proporcionou uma nova dinâmica no processo de liberação de informações (Sandoval-Almazán, 2015). Governos eletrônicos em geral são formados essencialmente por sites, tecnologias baseadas na web (Wong \& Welch, 2004) e oferecem serviços públicos aos cidadãos (Neves \& Silva, 2021). Esta tecnologia da era digital levou a um ambiente operacional consideravelmente diferente para os governos e seus líderes eleitos (Lindquist \& Huse, 2017). Tal fato se deve ao processo da globalização que proporcionou o surgimento de forças (revolução da tecnologia da informação) que pressionaram organizações públicas por mudanças (Wong \& Welch, 2004). Outro fator que também pode pressionar os governos é a velocidade com que os dados e informações podem circular na sociedade (Lindquist \& Huse, 2017).

O avanço da tecnologia da informação tornou mais atraente a ideia de governo aberto na administração pública (Kornberger, Meyer, Brandtner, \& Höllerer, 2017). Deste modo, os gestores públicos argumentam em seus discursos que o governo aberto pode promover transparência, participação, colaboração, eficiência e eficácia (Kornberger et 
al., 2017). No entanto, mudanças nas formas e funções das organizações possibilitam que ações humanas (incluindo decisões) influenciem o uso e o desenvolvimento da tecnologia (Orlikowski, 2000). Isso sugere que a adoção de dados abertos pode ser habilitada e restringida por um governo (Janssen, Charalabidis, \& Zuiderwijk, 2012). Além disso, numa organização pública, quem detém o poder de tomar decisões define como a tecnologia é adotada e adaptada para as necessidades institucionais e organizacionais (Wong \& Welch, 2004).

O fato de ter que decidir sobre a abertura do governo e dos seus dados traz situações conflitantes para todos os interessados (agentes públicos, cidadãos, órgãos fiscalizadores etc.). A relação entre a abertura, o público e princípios burocráticos (sigilo, conhecimento especializado, documentos impressos e normas) resultam em tensões (Kornberger et al., 2017). Nos conflitos e tensões existentes no processo de abertura de governos, os gestores públicos precisam lidar com as partes interessadas que podem ajudá-los a alcançar os benefícios dos dados abertos, mas também podem ser vistas como uma ameaça se não forem tratadas adequadamente (Janssen, et al., 2012). Além disso, onde há a abertura em questões estratégicas, são observados outros tipos de tensões. $\mathrm{O}$ aumento da transparência exige uma demanda maior de inclusão e um aumento de inclusão exige maior transparência, o que pode resultar numa abertura completa ou em um fechamento total (Hautz, Seidl, \& Whittington, 2017).

Alguns desses gestores podem se defrontar com práticas contrárias às ideias de abertura de governos. A premissa do processo de abertura de difundir e compartilhar informação enfrenta tradições de controle hierárquico e informacional (Roy, 2014). O confronto entre o processo de abertura de governos e tradições burocráticas pode resultar em publicações de informações públicas de qualidade ruim (Koznov, Andreeva, Nikula, Maglyas, Muromtsev \& Radchenko, 2016). Além disso, alguns agentes públicos precisam compreender que a abertura de governos é uma ferramenta que pode ser usada a seu favor e não apenas uma obrigação (Koznov, et al., 2016).

A tecnologia destinada à transmissão de informações é utilizada para fortalecer redes políticas constituídas por camadas de autoridade e influência (Lacharite, 2011). Além disso, a burocracia centraliza e controla a informação para se garantir no poder (Wong \& Welch, 2004). 
A literatura internacional indica, que apesar de os governos promoverem a abertura por meio dos dados abertos, estes permanecem notavelmente opacos (Lindquist \& Huse, 2017). Em complemento à afirmação anterior, Michener, Contreras, \& Niskier (2018), declaram que "os políticos majoritariamente valorizam a opacidade em detrimento da transparência". Além disso, agentes públicos tendem a evitar a abertura de dados, pois isso daria ao público novas ideias que podem resultar em questões críticas (Janssen, et al., 2012).

A transparência também é um risco para o governo porque ela pode prejudicar suas operações e sua reputação (Bannister \& Connolly, 2011). Para evitar a exposição desnecessária de informações (secretas e confidenciais) que podem ser politicamente perigosas, órgãos governamentais podem adotar um nível mais alto de sigilo e isolamento do público (Wong \& Welch, 2004). Tal sigilo pode interagir com a transparência e gerar uma dinâmica nas relações sociais, políticas e econômicas (Cronin, 2020).

O processo de abertura de governos é influenciado por pressões externas e fatores organizacionais que geram choques em procedimentos institucionalizados. As pressões externas são exercidas por organizações internacionais que fixam princípios de abertura a serem observados por governos (Chatwin, Arku, \& Cleave, 2019). Em geral, governos estaduais e locais adotam tais princípios de forma semelhante, porém, o contexto local determina a implantação de outras premissas (Chatwin, Arku, \& Cleave, 2019). A forma como Chatwin et al. (2019) abordam a abertura dos governos, o contexto pode ser um elemento estático. Nos tópicos que tratam da teoria do paradoxo e das contratações durante o regime de exceção da pandemia Covid-19, a mudança de contexto pode alterar o equilíbrio entre as tensões e pressões até então existentes.

O contexto, a estrutura e o ambiente são fatores organizacionais compostos por demandas de cidadãos e funcionários que causam impacto nas dimensões (transparência, acessibilidade e participação) dos governos abertos (Grimmelikhuijsen \& Feeney, 2017). A soma das pressões externas com os fatores organizacionais citados promove o rompimento da burocracia estabelecida em governos locais. Apesar desse conflito entre abertura e burocracia, os governos locais e seus respectivos cidadãos extraem bons resultados financeiros e sociais (Kornberger, Meyer, Brandtner, \& Höllerer, 2017).

A disponibilização de dados abertos é um componente do processo de abertura de governos (Gonzalez-Zapata \& Heeks, 2015). A adoção de dados abertos é observada em 
contextos políticos totalmente diferentes um do outro. No governo monárquico absolutista da Arábia Saudita, a aplicação das normas de acesso à informação influenciou o emprego de dados abertos (Altayar, 2018). Além disso, o mesmo autor afirma que pressões externas (índices internacionais que avaliam governos eletrônicos) e internas (projeto de governo eletrônico) também impactaram a adoção de dados abertos por parte de Ministérios da Arábia Saudita. O regime democrático do Reino Unido é referência mundial no que diz respeito a adoção de dados abertos (Wang \& Shepherd, 2019). No entanto, o estudo destes autores apontou que a tempestividade, a dificuldade de acesso e a falta de granularidade dos dados abertos prejudicam a verificação desses pelos cidadãos.

Por exemplo, para vencer essas dificuldades, a realização de treinamentos para uso de dados abertos adaptados ao contexto local podem ser um meio para que os cidadãos possam usufruir dos benefícios dos dados abertos (Gascó-Hernández, Martin, Reggi, Pyo, \& Luna-Reyes, 2018). A avaliação e comparação entre funcionalidade de portais de dados abertos e contextos mostrou que aspectos técnicos (elementos com termos técnicos e estatísticos) são bem implementados enquanto que aspectos menos técnicos (elementos com termos menos técnicos compartilhados em redes sociais) são deficientes para usuários em geral (Nikiforova \& McBride, 2021).

Estudos que focaram a dimensão da transparência em governos abertos abordaram outras questões relacionadas ao tema. A pesquisa de Schnel (2018), revela que a evolução da transparência acompanhou o desenvolvimento da democracia na Romênia. No entanto, o mesmo estudo aponta que a transparência participativa e a qualidade das informações precisam ser aprimoradas. Assim, é possível depreender que os resquícios de regimes totalitários podem ser um impeditivo no avanço da abertura dos governos. Em municípios de países democráticos, como a Suíça, a autonomia dada a estes governos locais determina o grau de transparência das informações disponibilizadas (Keuffer \& Mabillard, 2019). Além disso, estes autores observaram que, em razão de particularidades contextuais, há uma grande diferença entre as práticas de transparência adotas por tais municípios.

Como visto, a discussão de abertura de governo (openness) é proeminente no exterior. No Brasil, há muitos estudos que discutem empiricamente a dimensão da transparência da abertura de governos. Klein, Klein, \& Luciano (2018), identificaram mecanismos que atendem as demandas dos usuários de informações (cidadãos, organizações sociais, entidades fiscalizadoras) públicas. Em tal estudo, também foi 
observado que poucos indivíduos buscam informações governamentais porque a baixa qualidade dos dados dificulta seu entendimento e causa desconfiança. A ausência de dados e a precariedade de sua qualidade podem ser consideradas como barreiras impostas por um governo que se entende como proprietário da informação (Luciano, Wiedenhöft, $\&$ Santos, 2018). Tais fatos podem estar associados ao atendimento parcial das normas que tratam do tema (Michener, Contreras, \& Niskier, 2018).

Outros estudos discutiram ainda a utilização de mídias sociais para cumprir a Lei No 12.527/2011 (Lei de Acesso à Informação - LAI) (Castro \& Dias, 2019), e o descompasso da transparência orçamentária nos estados brasileiros (Zuccolotto \& Teixeira, 2017). A pesquisa de Neves e Silva (2021) discutiu o uso de portais eletrônicos como ferramentas de governo eletrônico e observou que gestores públicos entendem, equivocadamente, que transparência é sinônimo de divulgar as informações exigidas pela legislação. Tal fato está associado com a transparência nominal, ou seja, o interesse dos governos em priorizar a quantidade de informações ao invés da qualidade (Heald, 2003).

Considerando os estudos apresentados nesta seção, em geral não analisam a dinâmica do contexto, tratando-o como um pano de fundo estático. É possível observar ainda que em geral não discutem a multiplicidade de interessados nos processos de abertura de governos, e como esses diversos interesses podem resultar em pressões favoráveis ou não à uma maior abertura. As tensões provocadas por tal diversidade de interesses e entendimentos poderiam ser melhores conhecidas e gerenciadas visando amenizar ou resolver tais tensões.

\subsection{Transparência fiscal no Brasil}

O processo de desenvolvimento da transparência de governos no Brasil ocorreu conforme o estabelecimento das normas que regulamentaram a divulgação de informações. O primeiro marco determinante da transparência governamental teve início com a Constituição Federal de 1988 (Zuccolotto \& Teixeira, 2014). A Constituição Federal prometeu ainda uma legislação que regulamentasse a gestão fiscal dos recursos públicos de forma transparente (Pereira Júnior, 2001). Para cumprir a promessa da Constituição Federal, foi promulgada a Lei Complementar $N^{o} 101$ de 2000, também conhecida como Lei de Responsabilidade Fiscal (LRF). Tal norma deu destaque para a 
transparência fiscal e definiu os mecanismos de controle das despesas e do endividamento público (Araújo \& Loureiro, 2005).

A regulamentação que trata de divulgação de informações governamentais deu mais um passo, e em 2009, a Lei Complementar N 131 ou Lei da Transparência Pública "inseriu dispositivos que ampliam a transparência da gestão dos recursos públicos" (Ferreira, Silva, Silva, \& Miranda, 2014, p.2). Em 2011, foi criada a Lei No 12.527/2011, também chamada como Lei de Acesso à Informação (LAI), que teve o objetivo de assegurar o direito de os indivíduos obterem informações de órgãos públicos garantido pela Constituição Federal de 1988 (Bernardes, Santos, \& Rover, 2015).

O conteúdo das normas relacionadas à transparência exige que os governos disponibilizem os dados em meios eletrônicos, como por exemplo, portais de transparência. Tais portais foram adaptados e aprimorados no decorrer do processo de amadurecimento da transparência pública.

Os estudos publicados que abordaram a questão dos portais de transparência desde a promulgação da Constituição Federal (1988) até os dias atuais registraram a evolução do conteúdo destas plataformas digitais nas três esferas governamentais (Federal, Estadual e Municipal).

A pesquisa de Platt Neto, Cruz e Vieira (2006), relata que o Governo Federal foi o precursor em divulgar informações sobre transferências e aplicação de recursos ao criar o Portal da Transparência em 1994. Platt Neto, Cruz, Ensslin e Ensslin (2007), mencionam que o governo brasileiro também criou outros portais que disponibilizavam informações sobre a contratação e acompanhamento de obras públicas. Loureiro et al. (2008), fornecem mais detalhes sobre o conteúdo do Portal da Transparência do Governo Federal. O estudo destes autores expõe que a atualização dos dados do portal era mensal e que eram especificados os preços dos materiais e serviços comprados, valores gastos com diárias de viagens entre outros. Silva, Cristovan, Cavalcante e Vechiato (2019, p. 110), observaram que em 2019, o Portal da Transparência do Governo Federal possuía "mecanismo de busca integrado e intuitivo, melhor usabilidade, mais recursos gráficos, integração com redes sociais, maior oferta de dados abertos, adequação a plataformas móveis, maior interatividade".

A literatura que trata dos portais de transparência dos governos estaduais e do Distrito Federal também apresenta a evolução de tais plataformas. A pesquisa de Pinho 
(2008), menciona que até o ano de 2005, o Distrito Federal (DF) e os Governos Estaduais que possuíam portais de transparência disponibilizavam informações sobre licitações e compras diariamente. No entanto, a mesma pesquisa aponta que os dados da execução orçamentária se referiam apenas aos exercícios anteriores. Sales (2012), relatou que até 2011, os Estados de Alagoas e Paraíba não tinham portais de transparência, enquanto os outros Estados e o Distrito Federal divulgavam dados sobre as suas respectivas receitas e despesas. O estudo de Abdala e Torres (2016), registrou que o portal da transparência do DF disponibilizava informações sobre convênios e pagamentos a servidores. Souza, Barbosa, Cabral e Santos (2019), mencionaram que o Estado do Ceará divulgava dentre outras informações, acompanhamento de execução de obras e relatórios de controle interno e externo.

Os estudos que observaram os portais de transparência municipais também registram evolução semelhante. Tais pesquisas apontaram a divulgação dos relatórios exigidos pela Lei de Responsabilidade Fiscal (Prado \& Loureiro, 2006), licitações, receitas, despesas, repasses para entidades conveniadas (Ribeiro, 2009), remuneração de servidores (Jacques, Quintana \& Macagnan, 2013) e parecer prévio de Tribunal de Contas (Sediyama, Anjos, \& Felix, 2018).

Atualmente, os governos locais disponibilizam parcialmente os dados exigidos em plataformas digitais que podem ser desenvolvidas pelos seus respectivos departamentos de TI ou adquiridas por meio de empresas especializadas em desenvolvimento de softwares para o setor público. O layout destas plataformas permite a integração entre os sistemas informatizados dos departamentos de uma prefeitura (contabilidade, administração de pessoal, patrimônio, compras e licitações etc.). A integração entre tais sistemas possibilita ainda que o compartilhamento de dados contribua para o processo de divulgação de informações dos governos locais.

O avanço tecnológico permitiu a integração entre sistemas informatizados dos departamentos de órgãos públicos municipais (contabilidade, administração de pessoal, patrimônio, compras e licitações etc.). No entanto, estudos demonstram que as informações disponibilizadas nos portais de transparência atendem parcialmente as normas exigidas. A pesquisa de Leite Filho, Colares e Andrade (2015), analisou os dados da execução orçamentária disponíveis nos sítios eletrônicos dos maiores municípios do Estado de Minas Gerais. O estudo concluiu que o conteúdo dos portais da transparência estava desatualizado, com informações sintetizadas difíceis de serem localizadas e 
entendidas. Antunes (2018), observou aspectos dos portais de transparência de órgãos públicos (federais e estaduais) relacionados ao acesso às opções de navegação, identificação e valor do conteúdo das informações. O estudo demonstrou que as informações eram divulgadas parcialmente, não atendiam as necessidades dos cidadãos em relação à divulgação de dados públicos e não despertavam o interesse para a participação em tomadas de decisão. A participação dos cidadãos nas decisões do governo também é prejudicada porque existe falta de teorização por parte da administração pública relacionada ao tema (Neves \& Silva, 2021).

Apesar de tais estudos demonstrarem essa realidade nacional, eles são criticados por analisarem o atendimento parcial das normas da transparência (Michener, 2019). O mesmo autor argumenta que em pesquisas que analisam o atendimento das normas da transparência, as métricas, métodos e a coleta de evidências podem ter sido realizadas de forma inadequada porque a avaliação de políticas de transparência foi prejudicada. Assim, no mesmo artigo, o autor aponta que pesquisas futuras podem tentar compreender a coordenação de políticas de transparência e como novos canais de informação são utilizados.

\subsection{Teoria de Paradoxos em organizações}

A complexidade e a dinâmica de procedimentos organizacionais provocam tensões, contradições e dilemas (Smith \& Lewis, 2011) que podem ser observados nos processos de abertura dos governos. Tensões ocorrem, por exemplo, quando há pressão de órgãos governamentais na relação entre a capacidade institucional e a qualidade dos dados abertos (Fan \& Zhao, 2017). Já as contradições são vistas onde o acesso a dados é dificultado por governos que adotam o direito de acesso à informação (Adu, 2018). Um dilema pode surgir quando há questionamentos se os gastos com publicização são importantes ou não (Wagner, 2017). Considerando o contexto que envolve as questões relacionadas à abertura dos governos, a Teoria do Paradoxo se mostra um instrumento com potencial para explicar tensões, contradições e dilemas (Smith \& Lewis, 2011; Schad, Lewis, Raisch, \& Smith, 2016).

Um paradoxo consiste em elementos que são contraditórios, inter-relacionados e persistentes ao longo do tempo (Smith \& Lewis, 2011). Poole \& van de Ven (1989), acrescentam ainda que o paradoxo é uma chave para entender como trabalhar com contradições e oposições teóricas incorporadas em tradições complexas. Putnam, 
Fairhurst \& Banghart (2016), entendem que paradoxos são contradições persistentes que se sobrepõem, se refletem e se transformam em situações irracionais ou estranhas. $\mathrm{O}$ estudo de Schad et al. (2016), reforça estas ideias ao definir que os paradoxos representam contradições persistentes entre elementos interdependentes e, que embora pareçam distintos e opostos, eles se definem.

Os termos "opostos" ou “oposições" mencionados nos estudos acima, geralmente dizem respeito a dois elementos totalmente diferentes um do outro, por exemplo: claro e escuro, bem e mal, positivo e negativo, forte e fraco (Chen, 2002). A interdependência entre os opostos significa que um está contido no outro, ou seja, não há como mencionar um sem considerar o outro (Chen, 2002). Além disso, a interdependência destaca os vínculos indissolúveis entre os elementos opostos (Schad et al., 2016). A compreensão destes conceitos fica clara no símbolo de uma filosofia chinesa, o yin e yang que representam o equilíbrio de energias opostas (Chen, 2002).

Entre os opostos podem ocorrer as tensões que, são persistentes e surgem quando as posições contrárias usam suas forças para que os seus objetivos/interesses sejam alcançados/atendidos (Smith \& Lewis, 2011). Neste processo, pode ocorrer um gerenciamento dessas forças a fim de que haja um equilíbrio entre elas (Smith \& Lewis, 2011). Putnam et al. (2016) afirmam ainda que as tensões causam estresse, ansiedade, desconforto ou agonia em momentos decisórios que podem proporcionar avanços no gerenciamento de posições antagônicas em contextos organizacionais.

As contradições são o cerne das tensões paradoxais (Schad et al., 2016). Putnam et al. (2016), definem as contradições como opostos bipolares que são mutuamente exclusivos e interdependentes, de modo que podem se definir e se negarem. Os mesmos autores afirmam que a continuidade das contradições presentes nos paradoxos cria dilemas, ou seja, situações com opções mutuamente exclusivas que dificultam as escolhas entre elas. Este processo de decisão gera ansiedade, pois existe a necessidade de avaliar as vantagens e desvantagens de cada alternativa (Putnam et al., 2016).

A vasta literatura que trata de paradoxos organizacionais traz outros termos importantes que estão relacionados com as tensões, contradições e dilemas (Putnam et al., 2016). A dualidade considera que pólos opostos são interdependentes, ou seja, não são mutuamente exclusivos ou antagônicos (Farjoun, 2010; Putnam et al., 2016). Em contrapartida, o dualismo considera que as posições contrárias podem ser separadas 
(Farjoun, 2010; Putnam et al., 2016). Farjoun (2010), destaca que dentro das questões que envolvem dualidade e dualismo existe uma ampla discussão sobre estabilidade e mudança em organizações públicas e privadas.

A Teoria da Contingência também aborda as tensões e contradições em organizações (Pang, Cropp, \& Cameron, 2006; Smith \& Lewis, 2011), em que elementos externos e internos à organização concorrem positiva ou negativamente para o resultado organizacional (Smith \& Lewis, 2011). No entanto, a Teoria do Paradoxo está mais alinhada com o objetivo deste estudo porque aborda a interdependência entre os opostos e explica como as organizações podem atender as demandas concorrentes simultaneamente (Smith \& Lewis, 2011).

Paradoxos estão presentes na sociedade, nas organizações e nos indivíduos, de forma complexa e dinâmica. A Teoria do Paradoxo foi adotada por este estudo para observar as tensões na publicização da terceirização de serviços em governos locais, e como a mudança repentina do contexto pela entrada da pandemia e da ampliação do uso de dispensas de licitações afetou o equilíbrio então existente da transparência de contratações de serviços por governos.

\subsubsection{Estudos empíricos na teoria do paradoxo}

Estudos empíricos sobre paradoxos presentes no Apêndice B estão organizados conforme seus respectivos problemas de pesquisa e discutem as tensões, contradições e dilemas que afetam as organizações e/ou indivíduos. Nas organizações, os elementos dos paradoxos se manifestam principalmente quando há a implantação de um novo processo ou uma mudança de procedimentos que podem ser repentinos ou não.

A implementação de novas regulamentações voltadas para organizações provoca o surgimento de contradições. Em governos centrais da África que estabeleceram leis de acesso à informação foram utilizados outros meios para minar os benefícios desta legislação (Adu, 2018). Uma mesma regulação elaborada para quebrar o monopólio de uma empresa de telecomunicação acabou por prejudicar a competitividade do mercado e consequentemente forçou atores envolvidos nos processos a criarem respostas adequadas para esta contradição (Jarzabkowski, Lê, \& Van de Ven, 2013).

As contradições são observadas nas mudanças de ciclos ou ainda a própria mudança pode ser um dos pólos do paradoxo. Numa empresa multinacional do setor 
energético, as contradições entre demandas de curto e longo prazo promovem mudanças de ciclos viciosos para ciclos virtuosos (Pradies, Tunarosa, Lewis, \& Courtois, 2020). Tais mudanças decorrem de novas respostas que incorporam dinâmicas virtuosas e rompem dinâmicas viciosas (Pradies, Tunarosa, Lewis, \& Courtois, 2020). A mudança tem como oposto a estabilidade. O paradoxo entre esses dois elementos foi observado em estudo numa indústria que produz componentes eletrônicos semicondutores, conhecidos como LED, a qual a estabilidade de processos possibilita mudanças e as mudanças propiciam estabilidade com maior eficiência (Lin, Qu, Li, \& Tian, 2019).

Novos processos ou mudanças de procedimentos em organizações também provocam contradições e tensões. A implantação de um sistema informatizado numa seguradora, foi produtivo (eficiente) no início e oneroso (inútil) no decorrer do tempo (Drummond, 2008). Segundo o autor, tal fato ocorre em razão de falhas não serem detectadas por círculos viciosos da empresa, ou seja, procedimentos administrativos que não evoluem. Numa organização híbrida formada por parceria público-privada, as mudanças de lógicas institucionais permitem que ações inovadoras sejam prejudicadas e favorecidas ao mesmo tempo (Jay, 2013). Além disso, contradições também ocorrem quando empresas concorrentes precisam cooperar uma com a outra ou quando organizações parceiras competem entre si, tal situação é conhecida como coopetição (Raza-Ullah, Bengtsson, \& Kock, 2014).

As contradições também ocorrem quando a reputação da organização pode ser questionada. A preocupação com a identidade de uma montadora de automóveis aumentou após a descoberta de fraude nos sistemas de emissão de poluentes dos seus veículos (Gaim, Clegg, \& Cunha, 2019). Tal fraude decorreu de uma decisão da diretoria geral que admitiu o paradoxo de implantar um sistema cuja realidade era ilusória, ou seja, um sistema dos veículos que apresentava índices de emissão de poluentes falsos (Gaim, Clegg, \& Cunha, 2019). A manutenção das reputações de grupos de reflexão depende do gerenciamento entre a necessidade de, ao mesmo tempo, estar próximo e distante de seus financiadores (Jezierska \& Sörbom, 2020).

A habilidade de gerenciar paradoxos é observada ainda em parcerias não governamentais locais e internacionais em países da África. Os paradoxos de pertencimento (envolve tensões entre as crenças e valores de identidade de um grupo) e organização (ocorre quando indivíduos precisam realizar papéis e ações inconsistentes), por exemplo, afetam a capacidade das parcerias organizacionais equilibrarem a dualidade 
entre exploração e o aproveitamento do conhecimento (Lannon \& Walsh, 2020). Por um lado, tal capacidade não é afetada negativamente pelos paradoxos de pertencimento enquanto os paradoxos de organização impedem a capacidade de tal equilíbrio (Lannon \& Walsh, 2020).

As contradições e tensões também são observadas em estudos empíricos sobre paradoxo que discutem os indivíduos nas organizações. Tais discussões abrangem temas como: tecnologia da informação (TI), discriminações, identidade, humor, equipes multidisciplinares, resolução de tensões, pandemia e relações colaborativas.

Profissionais que atuam com TI se deparam com paradoxos quando a mesma tecnologia empregada no teletrabalho também é utilizada para se aproximar dos colegas de trabalho (Leonardi, Treem, \& Jackson, 2010). Além disso, uma mesma solução de tecnologia (dispositivos móveis de e-mail) pode levar ao aumento ou à diminuição do envolvimento com o trabalho (Mazmanian, Orlikowski, \& Yates, 2013). Estes mesmos autores apontam ainda que este paradoxo gera tensões entre os interesses profissionais e pessoais do indivíduo. De maneira similar, uma mesma tecnologia digital pode ser uma fonte de oportunidades no local de trabalho e provocar impactos negativos nas vidas pessoais de profissionais em cargos gerenciais (Grigore, Molesworth, Miles, \& Glozer, 2021).

As pesquisas que observaram os paradoxos nas discriminações de raça e gênero revelaram as tensões e contradições nestas questões. Em relação à raça, a inclusão racial e a participação diversificada são restringidas de forma implícita nos discursos de imparcialidade política e privilégios da Cruz Vermelha Americana (CVA) (Groscurth, 2011). Questões sobre gêneros são observadas quando alunas de cursos universitários frequentados por maioria masculina precisam ser "invisíveis" se vestindo como rapazes e visíveis tendo um desempenho melhor do que os alunos homens (Van den Brink \& Stobbe, 2009).

As questões que envolvem identidade individual e organizacional causam tensões e contradições entre gerentes, funcionários e organizações. O estudo de Cuganesan, (2017), destacou as tensões entre gerentes e funcionários no processo de negociação da similaridade (senso de pertencimento) e da distinção (senso de singularidade) de suas identidades. As tensões e contradições de identidades organizacionais entre funcionários 
e empresa emergem quando processo de mudança cultural possibilita que seus colaboradores reclamem verbalmente (Cunha, Simpson, Clegg, \& Rego, 2018).

Outros estudos captaram os paradoxos por meio do humor dos funcionários das organizações pesquisadas. Tal humor pode revelar que respostas a um processo de mudança organizacional são consolidadas ou mutáveis (Hatch \& Erhlich, 1993). Jarzabkowski \& Lê (2017), mostraram por meio do humor que gerentes de multinacionais ocupam uma mesma posição com funções antagônicas: "guardas" dos subordinados e "prisioneiros" dos diretores superiores.

Os estudos sobre paradoxos que discutiram equipes multidisciplinares, relataram que as tensões entre especialidades médicas diferentes e métodos terapeuticos distintos são benéficas para o cumprimento de um propósito em comum (Huq, Reay, \& Chreim, 2017). Em equipe de futebol, a tensão é encontrada entre os interesses individuais dos jogadores e os objetivos da equipe como um todo (Silva, Cunha, Clegg, Neves, Rego, Rodrigues, 2014). Em ambos os estudos, os autores afirmaram que foi necessário um controle ou equilíbrio entre as tensões. Já em um contexto organizacional hospitalar, a saliência e latência das tensões contraditórias são percebidas e gerenciadas por gestores, médicos e enfermeiros para que a organização continue operando (Tuckermann, 2018).

Já no nível individual, algumas pesquisas abordaram como se dá a resolução de tensões, por exemplo, na transição da administração de uma empresa familiar para um CEO externo as tensões são resolvidas por mudanças comportamentais e estruturais (Van Helvert-Beugels, Nordqvist, \& Flören, 2020). Tal estudo demonstra que pode ocorrer tensões quando há troca de comando na gestão de uma organização e como tais tensões podem ser identificadas e superadas. Outro estudo observou que agentes de call center resolvem as tensões de satisfação de clientes, eficácia e eficiência simultaneamente por meio de estratégias de construção de solidariedade e controle de conversa (Clark, Tan, Murfett, Rogers, \& Ang, 2019). A resolução de tensões também ocorre no setor público. Em governos estaduais, a participação dos gestores públicos, consultores jurídicos e até mesmos normas conflitantes proporcionaram um equilíbrio entre as tensões que envolviam privacidade e transparência de compartilhamento de dados (Graham, Gooden, \& Martin, 2016).

Ainda no setor público, a divulgação de informações sobre a gravidade dos riscos da pandemia da Covid-19 causou um entendimento paradoxal por parte da população de 
Singapura (Wong \& Jensen, 2020). Tal entendimento é indicado pelos níveis altos de confiança que proporcionaram níveis menores de adoção das medidas de gerenciamento de riscos pela população (Wong \& Jensen, 2020).

No Brasil, há poucos estudos que observaram tensões e contradições em organizações. Precinotto, Dias, \& Aquino (2020), discutiram os paradoxos na divulgação da folha de pagamento de governos locais e observaram que a mesma legislação que trata da transparência pública, ao mesmo tempo, impulsiona a abertura, mas impõe limites que impedem o avanço da transparência.

Em um breve resumo dessa literatura, os paradoxos produzem impactos nas relações entre organizações e indivíduos (Apêndice B). Na literatura empírica analisada, os efeitos dos paradoxos são: (i) restrição do direito de acesso à informação; (ii) sistemas informatizados onerosos; (iii) reestruturação de processos; (iv) geração de resultados contraditórios; (v) coopetição; (vi) administração de obrigações e relacionamentos; (vii) tensão entre interesses pessoais e profissionais; (viii) restrição de inclusão diversificada; (ix) desconsideração de particularidades; (x) adaptação de comportamento e superação de expectativas; (xi) negociação de identidades; (xii) aprimoramento de inovação e criatividade; (xiii) ocupação de posições antagônicas; (xiv) geração de respostas consolidadas ou mutáveis; (xv) reversão de tensões negativas em resultados positivos; (xvi) resultados positivos entre interesses conflitantes; (xvii) transição de ciclo negativo para ciclo positivo; (xviii) estabilidade promove mudança e mudança causa estabilidade; (xix) ciclo vicioso incontrolável; (xx) proximidade e distância de financiadores; (xxi) equilíbrio entre exploração e aproveitamento de conhecimento; (xxii) saliência e latência de tensões contraditórias; (xxiii) mudanças comportamentais e estruturais; (xxiv) estratégias de atendimento; (xxv) participação conjunta; (xxvi) compreensão e conduta contraditórias.

As causas dos efeitos dos paradoxos citados acima são provenientes dos fatores indicados abaixo, sendo que cada numeral romano a seguir está ligado ao numeral romano do parágrafo anterior: (i) corrupção, abusos de direitos humanos, ausência de diversidade de mídias (Adu, 2018); (ii) medidas ineficientes para detectar falhas (Drummond, 2008); (iii) pressões regulatórias (Jarzabkowski, Lê, \& Van de Ven, 2013); (iv) conflitos entre lógicas de serviços públicos e privados (Jay, 2013); (v) cooperação entre concorrentes ou concorrência entre parcerias (Raza-Ullah, Bengtsson, \& Kock, 2014); (vi) descentralização de atividades e adoção de teletrabalho (Leonardi, Treem, \& Jackson, 
2010); (vii) disponibilidade permanente por meio da tecnologia da informação (Mazmanian, Orlikowski, \& Yates, 2013) ou impactos positivos e negativos na vida pessoal de gerentes (Grigore, Molesworth, Miles, \& Glozer, 2021); (viii) manutenção de privilégios (Groscurth, 2011); (ix) práticas de bullying no ambiente de trabalho (TyeWilliams \& Krone, 2017); (x) preconceito contra gênero feminino (Van den Brink \& Stobbe, 2009); (xi) necessidade de pertencimento e singularidade (Cuganesan, 2017); (xii) processo de mudança na cultura organizacional (Cunha, Simpson, Clegg, \& Rego, 2018); (xiii) posicionamento intermediário na organização (Hatch \& Erhlich, 1993); (xiv) pressões regulatórias (Jarzabkowski \& Lê, 2017); (xv) objetivo em comum com opções de resoluções antagônicas (Huq, Reay, \& Chreim, 2017); (xvi) objetivo em comum entre interesses particulares (Silva, et al., 2014); (xvii) incorporação de reações eficazes (Pradies, Tunarosa, Lewis, \& Courtois, 2020); (xviii) processos rotineiros, acumulação de conhecimentos e variação de mecanismos e tentativas (Lin, Qu, Li, \& Tian, 2019); (xix) escolha de encobrir uma meta impossível (Gaim, Clegg, \& Cunha, 2019); (xx) necessidade de manter reputação (Jezierska \& Sörbom, 2020); (xxi) elementos paradoxais de pertencimento e organização (Lannon \& Walsh, 2020); (xxii) continuidade de processos internos (Tuckermann, 2018); (xxiii) transição de administradores (Van Helvert-Beugels, Nordqvist, \& Flören, 2020); (xxiv) necessidade de resolver tensões simultaneamente (Clark, Tan, Murfett, Rogers, \& Ang, 2019); (xxv) privacidade e transparência de dados (Graham, Gooden, \& Martin, 2016); (xxvi) divulgação dos riscos sobre a pandemia (Wong \& Jensen, 2020). 


\section{TERCEIRIZAÇÃO E TRANSPARÊNCIA PRÉ E PÓS PANDEMIA}

\subsection{Ampliação da terceirização da mão de obra}

A terceirização pode ser considerada como uma ferramenta de gestão que visa contratar uma outra entidade para a realização de atividades acessórias e complementares (Carneiro, 2016). O uso deste instrumento de gestão teve início nos Estados Unidos após a Segunda Guerra Mundial (Bertoncini \& Simão, 2019), sendo que no Brasil, o processo de terceirização foi iniciado em meados da década de 1950 (Carneiro, 2016). Desde então, as legislações que tratam da terceirização passaram por muitas mudanças tanto no setor privado quanto no setor público (Bertoncini \& Simão, 2019).

Com a recente atualização de normas relacionadas à terceirização no setor privado ocorrida em 2017 (Rocha \& Valadares, 2019), as empresas vislumbraram a possibilidade de redução de custos e aumento de produtividade (Medeiros, 2019). Em 2018, este fato gerou um aumento na contratação de mão de obra terceirizada em que cerca de $22 \%$ de trabalhadores formais eram terceirizados (Bellintani, 2019). A norma da terceirização no setor privado influenciou a criação de uma legislação semelhante para o setor público na forma do Decreto N $^{\circ} 9.507 / 2018$ que passou a vigorar no início de 2019 e regula apenas a União (Rigolin, 2016). O impacto gerado pela terceirização no setor privado produziu efeitos semelhantes no setor público. Tal fato estimulou o aumento de discussões e questionamentos sobre as questões que envolvem limites de gastos com pessoal (estabelecidos pela Lei de Responsabilidade Fiscal) e terceirização.

O Decreto No 9.507/2018 assegurou que atividades institucionais (tomada de decisão e funções contidas no plano de cargos do respectivo órgão) sejam exercidas por servidores concursados (Scatolino, 2018). No entanto, existem casos em que funcionários terceirizados exercem atividades principais nos órgãos públicos (A. Silva, 2017).

O Decreto $N^{\circ} 9.507 / 2018$ ampliou ainda a possibilidade de terceirização de serviços de apoio administrativo (manutenção, conservação, segurança, atendimento, transporte, informática etc) (Scatolino, 2018). O mesmo autor alerta que caso os serviços terceirizados sejam contratados de maneira a não atender a legislação, os órgãos fiscalizadores (Tribunais de Contas, Ministério Público etc.) precisam ser acionados para que a lei seja cumprida.

A questão que envolve a contratação de serviços terceirizados com o objetivo de burlar os gastos com folha de pagamento (Di Pietro, 2009) é relevante e merece ser 
observada porque muitos municípios têm dificuldade em controlar este tipo de despesa. Segundo o Tribunal de Contas do Estado de São Paulo (TCE-SP), no primeiro quadrimestre de 2019, 1/3 dos municípios tinham gastos excessivos com pessoal e 73\% possuíam problemas orçamentários. Em relação ao encerramento do exercício de 2019, o TCE-SP divulgou uma notícia relatando que uma entre quatro prefeituras fechou o ano com gasto excessivo com pessoal. Tais fatos demonstram a complicada situação em que alguns municípios paulistas passam em relação ao atendimento dos limites de gastos com pessoal estabelecidos pela Lei de Responsabilidade Fiscal.

Diante deste problema de controle de gastos com pessoal, governos locais adotam a contratação de serviços terceirizados. Em pesquisa promovida pela Confederação Nacional dos Municípios (CNM) e realizada entre os meses de agosto a outubro de 2018 foi apontado que 69,5\% dos 4.132 municípios pesquisados, terceirizavam seus serviços (Alves, 2019). A mesma pesquisa revelou que a terceirização dos serviços mais recorrentes são: conservação; limpeza urbana; manejo de resíduos sólidos; transportes; informática; manutenção de prédios, equipamentos e instalações. A estratégia da terceirização de serviços ainda pode consistir em contratar advogados, contadores e médicos sem que possuam vínculo celetista ou estatutário (Motta, 2019). Outro fator importante indicado na pesquisa da CNM foi que os gestores justificam a terceirização de serviços em razão da preocupação de estarem dentro dos limites de gastos com pessoal.

A justificativa destes gestores pode estar associada com um dos objetivos da terceirização que é transformar custos fixos em custos variáveis (Chiavenato, 2008). Portanto, a administração pública ao terceirizar serviços, troca servidores efetivos (custos fixos) por funcionários terceirizados (custos variáveis). Tal troca implica ainda numa flexibilização dos gastos com pessoal em razão dos custos com funcionários terceirizados serem menores do que os custos com servidores contratados diretamente (A. Silva, 2017).

O aumento da contratação da terceirização de serviços no setor público (A. Silva, 2017) somado às discussões dos limites de gastos com pessoal demonstra que essas questões podem ter um impacto significativo nas contas de organizações públicas. Portanto, a evidenciação desses elementos por parte dos governos é importante para que os interessados possam acompanhar o processo de terceirização de serviços. 


\subsection{O posicionamento dos órgãos fiscalizadores e sindicatos}

O aumento da terceirização no setor público estabeleceu uma nova dinâmica nas relações trabalhistas que enfraqueceu forças sindicais e provocou questões jurídicas relacionadas a órgãos que exercem atividades fiscalizatórias (A. Silva, 2017). Tais órgãos têm suas ações limitadas conforme a jurisdição em que atuam. Alguns exemplos desses órgãos são: Ministério Público Federal (MPF) e Ministérios Públicos estaduais; Tribunal de Contas da União (TCU) e Tribunais de Contas estaduais e municipais; Controladoria Geral da União (CGU).

Existem muitos interessados nas questões que envolvem a terceirização de serviços no setor público, os quais serão detalhados na seção Métodos deste estudo. Aqui serão considerados os posicionamentos dos órgãos fiscalizadores e sindicatos. Esses tipos de organizações possuem funções distintas que causam tensões nas questões relacionadas aos gastos com pessoal e terceirização.

Os Tribunais de contas exercem poder coercitivo na limitação de gastos com pessoal e na análise da legalidade de serviços terceirizados. O Ministério Público do Trabalho tem o poder de investigar denúncias sobre a legalidade na contratação de mão de obra terceirizada (Biavaschi \& Droppa, 2011). As investigações também podem ocorrer em conjunto entre o MPF e o Ministério Público do Estado de São Paulo. Estes dois órgãos participaram da Operação Sevandija, que dentre outras questões, investigaram empresas que terceirizavam serviços para a Prefeitura de Ribeirão Preto (Morais, 2020).

Posto isso, em geral, o posicionamento dos órgãos fiscalizadores sobre o tema é o de permitir que a terceirização dos serviços não ocorra em atividades rotineiras dos órgãos públicos, devendo estas serem exercidas por seus respectivos servidores.

Os sindicatos desempenham uma atividade representativa (Meireles, 2001), que pressiona o aumento das despesas com servidores e questiona a terceirização dos serviços públicos. Alguns sindicatos que representam servidores públicos tem um posicionamento crítico em relação à terceirização. Em websites destas entidades representativas, as críticas voltadas para a terceirização são apontadas para fatos como: extinção dos concursos; declínio da qualidade do serviço público; condições de trabalho e direitos trabalhistas prejudicados; inconstitucionalidade; aumento da corrupção e acidentes de trabalho (Sintieftal, 2018; Apufpr, 2018; AssUFRGS, 2018; Fenasps, 2018). 
Os posicionamentos opostos entre órgãos fiscalizadores e sindicatos são reforçados durante a pandemia. O Tribunal de Contas dos Municípios do Estado da Bahia, numa consulta emitida sobre a continuidade de um contrato de transporte escolar enfatizou que os serviços terceirizados devem realizar atividades-meio dos órgãos públicos (Vieira, 2020). No Estado do Paraná, sindicatos que representam servidores estaduais são contrários à proposta do governo de terceirizar cargos públicos na área da Educação e da Saúde (R. Silva, 2020). Os sindicalistas argumentam que o Governador aproveita o momento da pandemia para tentar mostrar economia de recursos com as terceirizações (R. Silva, 2020).

\subsection{Corrupção em serviços terceirizados}

A corrupção pela perspectiva do interesse público ocorre quando agentes corruptos atuam para obter benefícios para si próprios às custas do que é público (Brei, 1996). Tal atuação entre esses agentes pode ocorrer em organizações que terceirizam serviços (O'Connell, 2016). Na administração pública, os casos de corrupção nas contratações de serviços podem aumentar devido ao impacto causado pela pandemia. (Gallego, Prem, \& Vargas, 2020).

Os casos de corrupção que serão expostos a seguir foram divulgados em noticiários e envolviam a terceirização de serviços como: médicos, limpeza, vigilância e coleta de lixo.

Na região sul do Brasil, nos anos de 2015 e 2019 foram descobertos três grandes esquemas de corrupção na contratação de serviços terceirizados de limpeza, vigilância, portaria, ascensorista e bilheteria (Campos, 2019; Freitas, 2015; Grizotti, 2015). Num dos casos, 19 empresas chegaram a faturar mais de R\$ 1 bilhão durante um período de 10 anos com contratos de terceirização (Costa \& Gularte, 2019).

Em um município do interior de São Paulo, foi constatada uma fraude na contratação de serviços terceirizados na área da saúde (Freitas, 2015). Neste caso, médicos, dentistas, enfermeiros, agentes de saúde e motoristas prestavam serviços para a prefeitura por meio da Associação dos Servidores e Funcionários Municipais. Um outro agravante deste caso se dá pelo fato de que o Secretário Municipal de Saúde à época também era o Presidente da referida Associação. 
Em 2017, nas cidades de Barretos-SP e Passos-MG, surgiu um caso suspeito de fraude em contratos de coleta de lixo, limpeza urbana e administração do aterro sanitário (EPTV, 2017). Em 2020, a empresa envolvida neste caso ressarciu aos cofres públicos mais de R\$ 10 milhões após acordo entre os réus e o Ministério Público (EPTV, 2020). A notícia sobre este caso não apresentou questões sobre irregularidades a respeito de funcionários terceirizados. No entanto, é evidente que algumas atividades exercidas pelos colaboradores desta empresa poderiam ser realizadas por servidores concursados.

No Estado do Paraná, um grupo desviou mais de R 1 milhão por meio de empresas terceirizadas que prestavam serviços médicos (G1 PR, 2019). A fraude ocorreu no Hospital Universitário de Londrina e envolvia uma servidora que duplicava lançamentos de serviços médicos para uma empresa cujo sócio era seu genro (G1 PR, 2019).

Os casos de corrupção apresentados acima demonstram que a terceirização de serviços envolve cifras altas e atrai corruptos. Além disso, tais casos evidenciam a diversidade de stakeholders envolvidos na terceirização de serviços públicos. Portanto, observar a dinâmica da publicização destes tipos de serviços antes e durante a pandemia pode contribuir para captar os paradoxos presentes neste fenômeno.

\subsection{Contratações durante o regime de exceção da pandemia COVID-19}

A pandemia do novo coronavírus (Sars-Cov-2) causador da doença Covid-19 levou a adoção de medidas de isolamento social, contratação de serviços e construção de hospitais de campanha (Dantas, 2020).

No Brasil, o estado de emergência e/ou calamidade pública passaram a ser largamente decretados a partir de março de 2020. Por meio do Decreto Legislativo $\mathrm{n}^{\mathrm{o}} 6$ de 20/03/2020, o Governo Federal reconheceu pela primeira vez o estado de calamidade pública desde o início da vigência da Lei de Responsabilidade Fiscal (Batista, 2020). Posteriormente, Unidades Federativas (UF) e municípios também decretaram tal estado.

A instalação deste regime de exceção permite que entidades governamentais aumentem os gastos públicos (Batista, 2020). Inclusive, este aumento de gastos pode compreender as despesas com pessoal e a contratação de serviços de mão de obra. Até a data de 31/12/2020, o Portal de Compras do Governo Federal registrou gastos que somavam mais de $\mathrm{R} \$ 6,8$ bilhões referentes a 10.378 processos de dispensa de licitação 
(Portal de Compras, 2021). Além disso, governos estaduais e municipais também estão destinando recursos para montagens de hospitais de campanha $(R 7,2020)$. Demais órgãos públicos estão contratando profissionais da saúde para trabalharem nestes hospitais (G1, 2020; IGESDF, 2020; Governo de São Paulo, 2020).

Em relação aos serviços de mão de obra, as entidades governamentais estão terceirizando atividades de suporte e atividades fins da área da saúde. A Prefeitura de Ribeirão Preto, por exemplo, contratou serviços de locação de ambulâncias com condutores, enfermeiros e combustível (Prefeitura de Ribeirão Preto/SP, 2020). Em Jundiaí, os serviços foram contratados para desinfetar áreas públicas (Prefeitura de Jundiaí, 2020). Já o Governo do Estado de São Paulo, contratou serviços de telemedicina no valor de R\$ 3,7 milhões (Governo de São Paulo, 2020).

Além da elevação dos gastos, a situação de calamidade causada pela pandemia pode propiciar um ambiente favorável para práticas corruptas (Costa, 2020). O Governo do Rio de Janeiro, investigou propostas de preços para construção de sete hospitais de campanha que possuem indícios de fraude (Guimarães, Zuba, Leitão, \& Martins, 2020). No Amazonas, o governo adquiriu ventiladores inadequados por um preço acima do praticado no mercado (Costa, 2020). No município paraibano de Aroeiras, a Polícia Federal apurou um superfaturamento na aquisição de livros para auxílio na disseminação de informação para o combate à pandemia (Peron, 2020).

Em 2020, a organização sem fins lucrativos Transparência Internacional em parceria com o Tribunal de Contas da União emitiu "Recomendações para Transparência de Contratações Emergenciais em repostas à Covid-19”. Segundo o relatório, foram consideradas as experiências internacionais de Portugal, Colômbia, Ucrânia, Paraguai e União Europeia. O documento foi divulgado no site do Tribunal de Contas da União em maio de 2020, no início do primeiro ano da pandemia no Brasil. O documento traz ainda recomendações como: destacar no portal do órgão público site específico destinado ao combate da Covid-19; divulgação das legislações que tratam do tema; fornecer de forma célere dados em formato aberto, detalhados, íntegros, compreensíveis e confiáveis para que sejam realizadas análises e comparações; fornecer meios de comunicação para demais esclarecimentos sobre combate à Covid-19; publicar relatórios com dados e informações consolidadas (Transparência Internacional, 2020). O documento destaca que apesar da flexibilização da contratação, a mesma regulação traz obrigação específica sobre transparência no art. $4 \S 2^{\circ}$ da Lei $n^{\circ} 13.979$ de 2020 (reproduzida a seguir): 
$\S 2^{\circ}$ Todas as contratações ou aquisições realizadas com fulcro nesta Lei serão imediatamente disponibilizadas em sítio oficial específico na rede mundial de computadores (internet), contendo, no que couber, além das informações previstas no $\S 3^{\circ}$ do art. $8^{\circ}$ da Lei ${ }^{\circ} 12.527$, de 18 de novembro de 2011 , o nome do contratado, o número de sua inscrição na Receita Federal do Brasil, o prazo contratual, o valor e o respectivo processo de contratação ou aquisição.

Observando a variação do entendimento que já aparecia na prática da divulgação durante os primeiros meses da pandemia, o relatório então destaca as informações mínimas que deveriam ser disponibilizadas a cada contratação.

A Transparência Internacional realizou ainda uma pesquisa entre junho e agosto de 2020 que avaliou o nível de transparência das contratações emergenciais destinadas ao combate da Covid-19 do Governo Federal e das 27 Unidades da Federação e suas capitais. Tal pesquisa avaliou a divulgação de informações exigidas pela Lei $\mathrm{N}^{0} 13.979 / 2020$, a disponibilização de canais de comunicação, a acessibilidade e o formato dos dados (Transparência Internacional, 2020). O resultado dessa pesquisa gerou um ranking e mostrou as variações entre as entidades pesquisadas.

Uma matéria jornalística revelou que as contratações irregulares também ocorrem em outras áreas que não são destinadas ao combate da pandemia. Durante o período de quarentena, um morador do município de Barra do Mendes-BA, verificou que algumas contratações publicadas no portal da transparência, como reformas de prédios, não foram entregues (TV Bahia, 2020). Também foi descoberto que a prefeitura contratou pessoas que já haviam morrido e aposentadas por invalidez para executar serviços de pedreiro e digitador (TV Bahia, 2020). Os pagamentos feitos aos contratados variaram entre R\$ 600,00 e R\$ 10 mil (TV Bahia, 2020).

A ocorrência de práticas corruptas fragiliza a transparência (Costa, 2020) e os governantes parecem não se preocupar com tal fato. Em abril de 2020, o Governo do Rio de Janeiro tentou ocultar informações de uma dispensa de licitação no valor de R $\$ 836$ milhões cujo propósito era administrar 1,4 mil leitos dos sete hospitais de campanha do estado (Nascimento, 2020). Na esfera Federal, o Governo emitiu uma Medida Provisória (MP 928/2020) que suspendeu os prazos de respostas via Lei de Acesso à Informação (Agência Senado, 2020). No entanto, o Supremo Tribunal Federal suspendeu as restrições da MP 928/2020 em razão de elas ofenderem o princípio da publicidade e da transparência 
(Supremo Tribunal Federal, 2020). Além disso, os Tribunais de Contas dos Estados de São Paulo e Rio de Janeiro alertaram seus jurisdicionados que divulgassem os contratos associados à pandemia conforme a exigência da legislação.

Tais tentativas de interferências nos conteúdos de informações disponibilizadas na internet podem estar associadas às diversas motivações de gestores da organização (Mahler \& Regan, 2006). Além disso, esses tipos de atos podem ser um dos efeitos da pandemia que tem a capacidade de produzir aumento e diminuição de divulgação de dados públicos (Alampay, 2020). Os atores envolvidos nesses atos e a volatidade da publicização de dados durante a pandemia demonstram a complexidade e dinamicidade da abertura dos governos. 


\section{MÉTODO}

A presente pesquisa utilizou como estratégia a comparação de casos múltiplos buscando uma explicação que acomode os casos pesquisados (Yin, 2001) para dar robustez e poder de convencimentos aos resultados (Herriott \& Firestone, 1983).

Os primeiros passos da presente pesquisa ocorreram poucos meses antes da Organização Mundial da Saúde declarar a pandemia da Covid-19 em março de 2020. A princípio, o objeto de análise eram os paradoxos presentes publicização da folha de pagamento de governos locais. Contadores de prefeituras foram entrevistados sobre questões que envolviam os sistemas contábeis informatizados e as barreiras encontradas na divulgação de informações de tais sistemas. A amostra analisada era composta por prefeituras auditadas por um mesmo Tribunal de Contas e com uma mesma empresa que fornecesse a integração entre o sistema de contabilidade pública e o sistema de portal de transparência.

Por conveniência a pesquisa observou organizações localizadas no Estado de São Paulo em razão da possível facilidade em obter entrevistas presenciais com os contadores de prefeituras e demais interessados na divulgação de informações públicas. No entanto, após o início da pandemia as entrevistas ocorreram remotamente. Além disso, o Estado de São Paulo foi escolhido em razão de ser a Unidade Federativa mais afetada pela pandemia conforme registro do número de novos casos (Sandes, 2020). O Estado de São Paulo também implantou o Plano São Paulo, que é uma estratégia de retomada segura da economia baseada em métricas e critérios que utiliza taxa de ocupação de leitos de UTI exclusivas para pacientes com coronavírus, número de novas internações e número de óbitos (Estado de São Paulo, 2020).

A presente pesquisa considerou que a pandemia poderia afetar os contadores e demais interessados em dados públicos. Assim, a pesquisa ampliou sua observação para a publicização das dispensas de licitações e serviços terceirizados em governos locais. As questões que envolvem divulgação de folha de pagamento já foram discutidas em artigo submetido a um periódico nacional. Logo, a dissertação passou a focar na divulgação de atos de contratação de serviços via dispensa de licitação durante a pandemia. Além dos documentos de dispensa de licitação, a pesquisa também coletou nos diários oficiais e nos portais de transparência outros tipos de documentos que mencionavam a pandemia. No 
entanto, os únicos documentos analisados foram as dispensas de licitações porque este tipo de contratação é muito utilizado no regime de exceção causado pela pandemia.

Durante tal processo de observação, as prefeituras e demais interessados tiveram que se adaptar rapidamente às novas normas que delimitavam a divulgação e as compras destinadas ao combate da pandemia.

A observação desta adaptação coletou nos portais de transparência dos municípios estudados documentos relacionados aos atos de dispensa de licitação realizados entre março e dezembro de 2019 e março e dezembro de 2020. Este estudo selecionou tais períodos para comparação porque a pandemia começou em março de 2020 e os mandatos dos prefeitos foram concluídos em dezembro de 2020.

\subsection{Amostra}

O ponto de partida para considerar a amostra final foi selecionar os 172 municípios paulistas avaliados pela Controladoria Geral da União (CGU) entre os anos de 2015 e 2017. Tal consideração levou em conta o objetivo da avaliação da Controladoria Geral da União que mediu a transparência pública por meio das competências exigidas pelas legislações pertinentes.

Entre agosto de 2019 e março de 2020, foram enviados pedidos de informação para estes municípios questionando quais eram as empresas fornecedoras do portal de transparência (fiscal) e Sistema de Administração de Dados Administrativos e Financeiros (SIAFIC) e desde quando os referidos serviços eram prestados. O propósito das questões enviadas aos municípios foi captar a integração entre os sistemas utilizados pelas prefeituras. A integração entre tais sistemas, em alguns momentos registra atos e fatos ocorridos antes, durante e depois da execução orçamentária, inclusive o processo de contratação de serviços. Até o final do mês de março de 2020, noventa e oito prefeituras responderam os pedidos de informação. Então, o presente estudo optou por analisar os 32 municípios de um mesmo provedor de serviços de TI (dentre os que responderam ao pedido de informação), visando observar apenas um sistema ao invés de comparar soluções tecnológicas de empresas diferentes. Além disso, tal opção acaba por excluir questões entre integração de fornecedores de sistemas diferentes.

Por meio das respostas dos pedidos de informação enviados para as prefeituras selecionadas, a pesquisa identificou 19 fornecedores de TI diferentes (com concentração 
em 3 fornecedores mais recorrentes) e 3 municípios cujos portais da transparência eram desenvolvidos pelos setores de Tecnologia da Informação. As duas unidades de análise da pesquisa são: (i) prefeituras do interior paulista; (ii) divulgação de atos de dispensa de licitação realizados entre março e dezembro de 2019 e março e dezembro de 2020.

O presente estudo seguiu dois critérios na seleção dos municípios analisados. O primeiro critério foi escolher municípios localizados no interior do Estado de São Paulo que tiveram aspectos de transparência ativa e passiva avaliados pela Controladoria Geral da União entre 2015 e 2017. O segundo critério foi selecionar municípios que contrataram um único fornecedor de serviços de TI que tivesse os sistemas de contabilidade pública e portal de transparência integrados. A opção por observar sistemas integrados visou isolar possíveis barreiras entre sistemas diferentes que dificultariam a divulgação de informações públicas.

A escolha da amostra dos municípios analisados foi estabelecida antes da pandemia. Logo, o contexto pandêmico não pode ser controlado já que os municípios da amostra reagiram de maneiras distintas em relação ao histórico local de casos, mortes, ocupação de leitos em hospitais e vacinação durante uma mesma semana epidemiológica. A Figura 1 mostra os 32 municípios (casos) em análise distribuídos no Estado de São Paulo. Cada marcador na Figura 1 representa a localização aproximada dos municípios estudados e os números dos marcadores representam os casos conforme constam na Tabela 1. 
Figura 1. Distribuição dos casos no estado de São Paulo

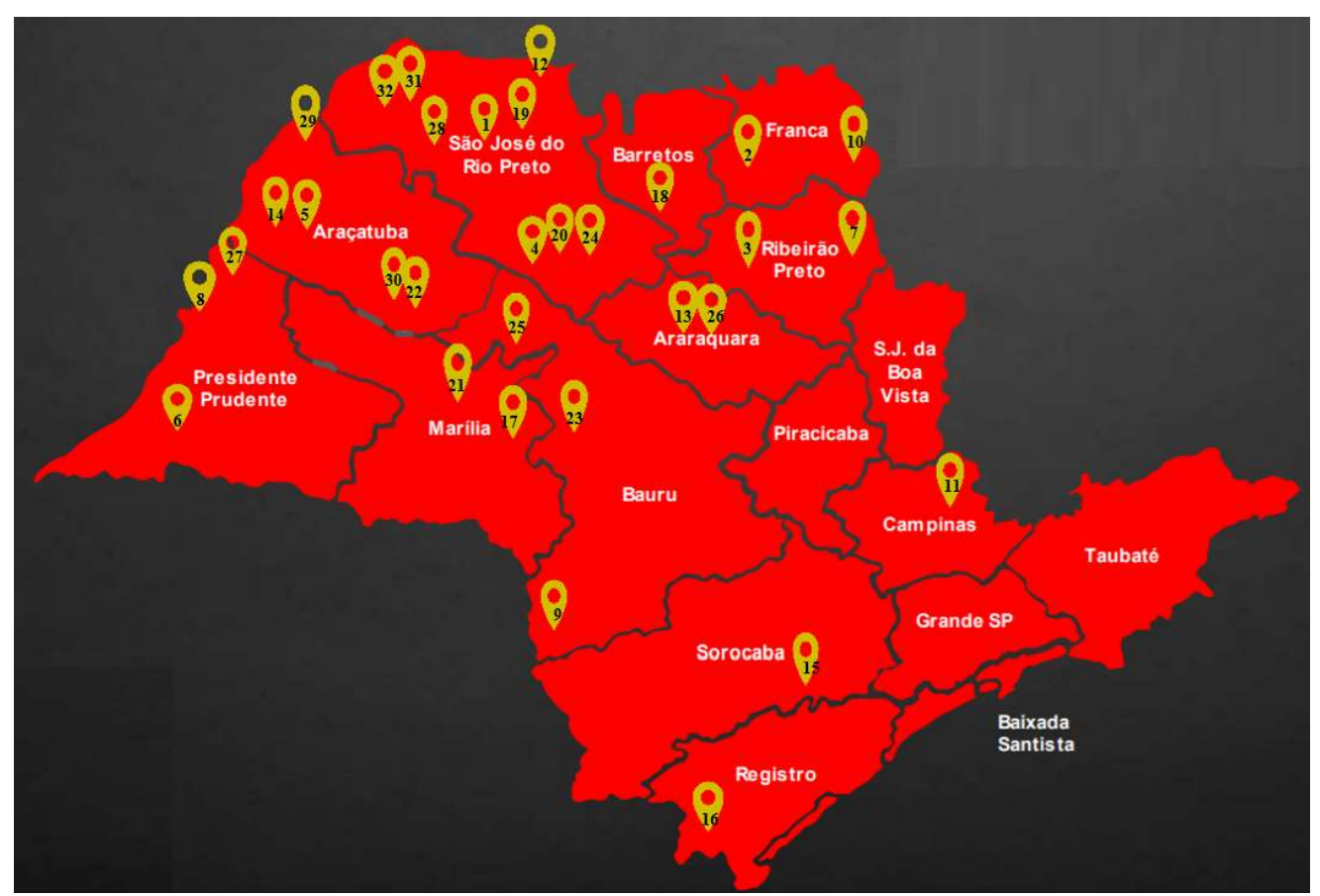

Fonte: Elaborada pelo autor como base no Plano São Paulo.

A Tabela 1 (municípios da amostra) apresenta detalhes dos municípios em análise. A amostra contempla municípios em diversos momentos da entrada da pandemia no interior de São Paulo. Com a chegada da pandemia o Governo do Estado procurou coordenar em nível estadual medidas sanitárias por meio do Plano São Paulo. Tal plano foi um instrumento do governo estadual que tinha a intenção de recuperar a economia abalada pela pandemia com base em indicadores como taxa de ocupação de leitos de UTI e número de óbitos relacionados com o novo coronavírus. Segundo o governo estadual, tal recuperação se daria provocando um distanciamento social que evitaria a disseminação da Covid-19. Este distanciamento social aconteceria por meio de abertura e fechamento parciais ou totais de comércios, serviços e demais entidades.

Neste plano criado em 2020, o governo estadual dividiu o estado em 17 Regiões de Saúde e estabeleceu cinco fases de quarentena para classificar a situação de cada região (G1 SP, 2021). Para cada fase foi atribuída uma cor que indicava a evolução da situação de cada região. As fases eram: vermelha (Alerta Máximo); laranja (Controle); amarela (Flexibilização); verde (Abertura parcial); azul (Normal controlado) (G1 SP, 2021).

A Tabela 1 (municípios da amostra) mostra a quantidade de semanas na fase vermelha e quantidade de mortes por Covid-19 no período em análise. A taxa de mortes por habitante e número de semanas na fase vermelha do Plano São Paulo, e as 
consequentes medidas de lock-down e fechamento do comércio dão uma noção da pressão existente nas cidades estudadas. 
Tabela 1. Municípios da amostra acompanhados durante a pandemia COVID-19 entre 11/03/2020 a 31/12/2020

\begin{tabular}{|c|c|c|c|c|c|c|c|c|c|c|}
\hline Casos & $\begin{array}{l}\text { Distância } \\
\text { aproximada da } \\
\text { capital }(\mathbf{k m})\end{array}$ & $\begin{array}{c}\text { População } \\
\text { aproximada } \\
\text { (em milhares } \\
\text { de habitantes) }\end{array}$ & Data $1^{\text {a }}$ morte & $\begin{array}{c}\text { Semana } \\
\text { epidemiológica } \\
\text { (referente à data } \\
\text { da } 1^{\mathrm{a}} \text { morte) }\end{array}$ & $\begin{array}{c}\text { Semana } \\
\text { epidemiológica } \\
\text { (referente a } \\
\text { data } 1^{\mathrm{a}} \text { vez na } \\
\text { fase vermelha- } \\
\text { Tabela 2) } \\
\end{array}$ & $\begin{array}{c}\text { Data do } \\
\text { decreto de } \\
\text { Emergência }\end{array}$ & $\begin{array}{c}\text { Data do } \\
\text { decreto } \\
\text { Calamidade }\end{array}$ & $\begin{array}{l}\text { Quantidade } \\
\text { de semanas na } \\
\text { fase vermelha }\end{array}$ & $\begin{array}{l}\text { Quantidade } \\
\text { de mortes }\end{array}$ & $\begin{array}{l}\text { Quantidade de } \\
\text { mortes por } \\
100.000 \\
\text { habitante }\end{array}$ \\
\hline 1 & 500 & 90 & $11 / 05 / 20$ & 20 & - & $16 / 03 / 20$ & $01 / 04 / 20$ & 0 & 123 & 134,75 \\
\hline 2 & 400 & 50 & $27 / 06 / 20$ & 26 & 27 & $20 / 03 / 20$ & $23 / 03 / 20$ & 6 & 32 & 63,86 \\
\hline 3 & 400 & 46 & $24 / 04 / 20$ & 17 & 25 & $07 / 04 / 20$ & $05 / 05 / 20$ & 7 & 55 & 119,62 \\
\hline 4 & 500 & 35 & $12 / 05 / 20$ & 20 & - & $20 / 03 / 20$ & - & 0 & 27 & 75,98 \\
\hline 5 & 600 & 30 & $24 / 04 / 20$ & 17 & 27 & $18 / 03 / 20$ & $28 / 05 / 20$ & 3 & 11 & 37,87 \\
\hline 6 & 600 & 20 & $07 / 05 / 20$ & 19 & 26 & $17 / 03 / 20$ & - & 3 & 14 & 67,06 \\
\hline 7 & 300 & 15 & $04 / 07 / 20$ & 27 & 25 & $23 / 03 / 20$ & $17 / 04 / 20$ & 7 & 8 & 49,45 \\
\hline 8 & 700 & 15 & $15 / 05 / 20$ & 20 & 25 & $21 / 03 / 20$ & $01 / 04 / 20$ & 4 & 8 & 51,75 \\
\hline 9 & 400 & 15 & $22 / 07 / 20$ & 30 & 27 & $17 / 03 / 20$ & - & 2 & 7 & 46,31 \\
\hline 10 & 400 & 15 & $05 / 08 / 20$ & 32 & 27 & $19 / 03 / 20$ & $30 / 03 / 20$ & 6 & 8 & 56,77 \\
\hline 11 & 100 & 13 & $06 / 08 / 20$ & 32 & 28 & $19 / 03 / 20$ & - & 2 & 4 & 29,91 \\
\hline 12 & 600 & 12 & $17 / 08 / 20$ & 34 & - & - & $30 / 03 / 20$ & 0 & 3 & 25,50 \\
\hline 13 & 300 & 9 & $30 / 09 / 20$ & 40 & - & $20 / 03 / 20$ & $15 / 04 / 20$ & 0 & 2 & 23,28 \\
\hline 14 & 600 & 9 & $05 / 09 / 20$ & 36 & 27 & $23 / 03 / 20$ & $08 / 04 / 20$ & 3 & 1 & 11,73 \\
\hline 15 & 100 & 8 & $26 / 08 / 20$ & 35 & 27 & - & $31 / 03 / 20$ & 2 & 4 & 49,71 \\
\hline 16 & 300 & 8 & $18 / 05 / 20$ & 21 & 23 & $19 / 03 / 20$ & $02 / 04 / 20$ & 6 & 6 & 76,65 \\
\hline 17 & 400 & 7 & $03 / 09 / 20$ & 36 & 26 & $23 / 03 / 20$ & $06 / 04 / 20$ & 3 & 5 & 72,53 \\
\hline 18 & 400 & 7 & $14 / 05 / 20$ & 20 & 25 & - & - & 2 & 3 & 43,59 \\
\hline 19 & 500 & 6 & $19 / 07 / 20$ & 30 & - & $23 / 03 / 20$ & - & 0 & 12 & 201,95 \\
\hline 20 & 500 & 6 & $22 / 08 / 20$ & 34 & - & - & $16 / 07 / 20$ & 0 & 5 & 84,60 \\
\hline 21 & 500 & 6 & $04 / 06 / 20$ & 23 & 26 & - & - & 3 & 3 & 52,04 \\
\hline 22 & 500 & 6 & $29 / 06 / 20$ & 27 & 27 & $21 / 03 / 20$ & $18 / 06 / 20$ & 3 & 7 & 123,11 \\
\hline 23 & 500 & 6 & $09 / 06 / 20$ & 24 & 27 & $20 / 03 / 20$ & $30 / 03 / 20$ & 2 & 8 & 145,40 \\
\hline 24 & 500 & 5 & $04 / 06 / 20$ & 23 & - & - & - & 0 & 10 & 182,15 \\
\hline 25 & 400 & 5 & $14 / 08 / 20$ & 33 & 27 & $24 / 03 / 20$ & $08 / 04 / 20$ & 2 & 3 & 56,87 \\
\hline 26 & 300 & 5 & $08 / 08 / 20$ & 32 & - & $20 / 03 / 20$ & $31 / 03 / 20$ & 0 & 3 & 65,12 \\
\hline 27 & 700 & 4 & $14 / 08 / 20$ & 33 & 25 & $28 / 05 / 20$ & - & 4 & 5 & 120,02 \\
\hline 28 & 600 & 4 & $20 / 08 / 20$ & 34 & - & - & $27 / 03 / 20$ & 0 & 5 & 127,81 \\
\hline 29 & 600 & 4 & $21 / 10 / 20$ & 43 & 27 & $20 / 03 / 20$ & $16 / 04 / 20$ & 3 & 2 & 53,45 \\
\hline 30 & 500 & 3 & $27 / 06 / 20$ & 26 & 27 & $25 / 03 / 20$ & $27 / 05 / 20$ & 3 & 4 & 144,09 \\
\hline 31 & 600 & 2 & $31 / 05 / 20$ & 23 & - & $23 / 03 / 20$ & $04 / 06 / 20$ & 0 & 5 & 236,41 \\
\hline 32 & 600 & 2 & $26 / 02 / 21 *$ & 8 & - & - & $24 / 03 / 20$ & 0 & 0 & 0,00 \\
\hline
\end{tabular}

Fonte: Elaborada pelo autor com base em Congresso em Foco, 2020; Secretaria de Estado de Saúde de Goiás, 2020; Estado de São Paulo, 2020. 
Nota: * Caso 32 - Primeira morte ocorreu em 2021. 
De certa forma, a Tabela 2 mostra a dinâmica da pandemia e as medidas de resposta nos casos estudados. Para analisar esta dinâmica e as medidas de resposta, a pesquisa utilizou como referência o desenrolar do Plano São Paulo de março de 2020 a dezembro de 2020, no primeiro ano da pandemia de Covid-19. A Tabela 2 apresenta as semanas do Plano São Paulo no primeiro ano da pandemia.

Em geral, quando o Governo de São Paulo determinava, por meio do Plano São Paulo, que as regiões entrassem na fase laranja, era esperado que os municípios proibissem a abertura de bares, restaurantes, salões de beleza ou academias. Ainda na fase laranja era permitida a abertura parcial de comércio de rua, shoppings centers e similares (G1 SP, 2020). Já na fase vermelha o governo estadual estabeleceu que fossem abertos apenas estabelecimentos e entidades que fornecessem materiais e serviços essenciais como supermercados, farmácias, clínicas, bancos etc (Folha de SP, 2020). Ainda com o objetivo de ampliar o isolamento social, o governo estadual propôs a antecipação de feriados (Estado de São Paulo, 2020). Somado a isso, alguns municípios do litoral paulista criaram barreiras sanitárias para a chegada de turistas durante feriados prolongados (G1 SP, 2020).

O Plano São Paulo atualizava periodicamente as classificações das regiões. O tempo entre uma atualização e outra ocorria conforme as fases indicavam situações mais críticas (Tabela 2). A Tabela 2 mostra ainda a evolução das fases de cada caso e sua respectiva região durante as 16 atualizações do Plano São Paulo em 2020.

As constantes atualizações do Plano São Paulo que determinavam restrições na abertura de empresas provocaram atritos entre prefeitos paulistas e o Governo de São Paulo. Em dezembro de 2020, 18 prefeitos paulistas não cumpriram o decreto estadual e permitiram que atividades não essenciais continuassem em funcionamento (Marangoni, 2020). 
Tabela 2. Determinação pelo Governo do Estado de São Paulo pelo Plano São Paulo.

\begin{tabular}{|c|c|c|c|c|c|c|c|c|c|c|c|c|c|c|c|c|c|}
\hline Casos & $\begin{array}{l}\text { Região do Estado de São Paulo } \\
\text { em que o caso está localizado }\end{array}$ & 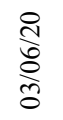 & 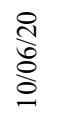 & $\begin{array}{l}\stackrel{\mathrm{N}}{\mathrm{o}} \\
\stackrel{2}{\Omega}\end{array}$ & 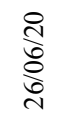 & 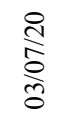 & $\frac{\stackrel{\mathrm{N}}{\mathrm{S}}}{\stackrel{0}{0}}$ & 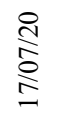 & $\begin{array}{l}\stackrel{\text { N }}{\hat{S}} \\
\underset{\text { d }}{+}\end{array}$ & 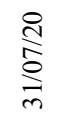 & 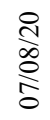 & 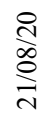 & 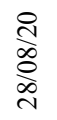 & 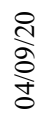 & 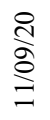 & 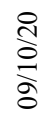 & 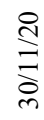 \\
\hline 1 & DRS 15 - S.J. Rio Preto & 2 & 2 & 2 & 2 & 2 & 2 & 2 & 2 & 2 & 2 & 2 & 2 & 3 & 3 & 3 & 3 \\
\hline 2 & \begin{tabular}{|l|} 
DRS 08 - Franca \\
\end{tabular} & 2 & 2 & 2 & 2 & 1 & 1 & 1 & 1 & 1 & 1 & 2 & 2 & 2 & 3 & 3 & 3 \\
\hline 3 & DRS 13 - Ribeirão Preto & 2 & 2 & 1 & 1 & 1 & 1 & 1 & 1 & 1 & 3 & 3 & 3 & 2 & 3 & 3 & 3 \\
\hline 4 & DRS 15 - S.J. Rio Preto & 2 & 2 & 2 & 2 & 2 & 2 & 2 & 2 & 2 & 2 & 2 & 2 & 3 & 3 & 3 & 3 \\
\hline 5 & DRS 02 - Araçatuba & 2 & 2 & 2 & 2 & 1 & 1 & 1 & 2 & 2 & 3 & 3 & 3 & 3 & 3 & 3 & 3 \\
\hline 6 & DRS 09 - Marília & 2 & 2 & 2 & 1 & 1 & 1 & 2 & 2 & 2 & 3 & 2 & 2 & 3 & 3 & 3 & 3 \\
\hline 7 & DRS 13 - Ribeirão Preto & 2 & 2 & 1 & 1 & 1 & 1 & 1 & 1 & 1 & 3 & 3 & 3 & 2 & 3 & 3 & 3 \\
\hline 8 & DRS 11 - Presidente Prudente & 3 & 3 & 1 & 1 & 1 & 1 & 2 & 2 & 2 & 2 & 2 & 2 & 3 & 3 & 3 & 3 \\
\hline 9 & \begin{tabular}{|l|} 
DRS 06 - Bauru \\
\end{tabular} & 3 & 3 & 2 & 2 & 1 & 1 & 2 & 2 & 2 & 3 & 3 & 3 & 3 & 3 & 3 & 3 \\
\hline 10 & DRS 08 - Franca & 2 & 2 & 2 & 2 & 1 & 1 & 1 & 1 & 1 & 1 & 2 & 2 & 2 & 3 & 3 & 3 \\
\hline 11 & DRS 07 - Campinas & 2 & 2 & 2 & 2 & 2 & 1 & 1 & 2 & 2 & 3 & 3 & 3 & 3 & 3 & 4 & 3 \\
\hline 12 & DRS 15 - S.J. Rio Preto & 2 & 2 & 2 & 2 & 2 & 2 & 2 & 2 & 2 & 2 & 2 & 2 & 3 & 3 & 3 & 3 \\
\hline 13 & DRS 03 - Araraquara & 3 & 3 & 2 & 2 & 2 & 2 & 2 & 3 & 3 & 3 & 3 & 3 & 3 & 3 & 3 & 3 \\
\hline 14 & \begin{tabular}{|l|} 
DRS 02 - Araçatuba \\
\end{tabular} & 2 & 2 & 2 & 2 & 1 & 1 & 1 & 2 & 2 & 3 & 3 & 3 & 3 & 3 & 3 & 3 \\
\hline 15 & DRS 16 - Sorocaba & 2 & 2 & 2 & 2 & 1 & 1 & 2 & 2 & 2 & 3 & 3 & 3 & 3 & 3 & 4 & 3 \\
\hline 16 & DRS 12 - Registro & 1 & 1 & 2 & 1 & 1 & 1 & 3 & 3 & 1 & 1 & 2 & 2 & 3 & 3 & 3 & 3 \\
\hline 17 & DRS 09 - Marília & 2 & 2 & 2 & 1 & 1 & 1 & 2 & 2 & 2 & 3 & 2 & 2 & 3 & 3 & 3 & 3 \\
\hline 18 & DRS 05 - Barretos & 3 & 3 & 1 & 1 & 2 & 2 & 2 & 2 & 2 & 2 & 3 & 3 & 3 & 3 & 2 & 3 \\
\hline 19 & DRS 15 - S.J. Rio Preto & 2 & 2 & 2 & 2 & 2 & 2 & 2 & 2 & 2 & 2 & 2 & 2 & 3 & 3 & 3 & 3 \\
\hline 20 & DRS 15 - S.J. Rio Preto & 2 & 2 & 2 & 2 & 2 & 2 & 2 & 2 & 2 & 2 & 2 & 2 & 3 & 3 & 3 & 3 \\
\hline 21 & DRS 09 - Marília & 2 & 2 & 2 & 1 & 1 & 1 & 2 & 2 & 2 & 3 & 2 & 2 & 3 & 3 & 3 & 3 \\
\hline 22 & DRS 02 - Araçatuba & 2 & 2 & 2 & 2 & 1 & 1 & 1 & 2 & 2 & 3 & 3 & 3 & 3 & 3 & 3 & 3 \\
\hline 23 & DRS 06 - Bauru & 3 & 3 & 2 & 2 & 1 & 1 & 2 & 2 & 2 & 3 & 3 & 3 & 3 & 3 & 3 & 3 \\
\hline 24 & DRS 15 - S.J. Rio Preto & 2 & 2 & 2 & 2 & 2 & 2 & 2 & 2 & 2 & 2 & 2 & 2 & 3 & 3 & 3 & 3 \\
\hline 25 & DRS 06 - Bauru & 3 & 3 & 2 & 2 & 1 & 1 & 2 & 2 & 2 & 3 & 3 & 3 & 3 & 3 & 3 & 3 \\
\hline 26 & DRS 03 - Araraquara & 3 & 3 & 2 & 2 & 2 & 2 & 2 & 3 & 3 & 3 & 3 & 3 & 3 & 3 & 3 & 3 \\
\hline 27 & DRS 11 - Presidente Prudente & 3 & 3 & $\overline{1}$ & 1 & 1 & $\overline{1}$ & 2 & 2 & 2 & 2 & 2 & 2 & 3 & 3 & 3 & 3 \\
\hline 28 & DRS 15 - S.J. Rio Preto & 2 & 2 & 2 & 2 & 2 & 2 & 2 & 2 & 2 & 2 & 2 & 2 & 3 & 3 & 3 & 3 \\
\hline 29 & DRS 02 - Araçatuba & 2 & 2 & 2 & 2 & 1 & 1 & 1 & 2 & 2 & 3 & 3 & 3 & 3 & 3 & 3 & 3 \\
\hline 30 & DRS 02 - Araçatuba & 2 & 2 & 2 & 2 & 1 & 1 & 1 & 2 & 2 & 3 & 3 & 3 & 3 & 3 & 3 & 3 \\
\hline 31 & DRS 15 - S.J. Rio Preto & 2 & 2 & 2 & 2 & 2 & 2 & 2 & 2 & 2 & 2 & 2 & 2 & 3 & 3 & 3 & 3 \\
\hline 32 & DRS 15 - S.J. Rio Preto & 2 & 2 & 2 & 2 & 2 & 2 & 2 & 2 & 2 & 2 & 2 & 2 & 3 & 3 & 3 & 3 \\
\hline
\end{tabular}

Legenda: Fase 1 (vermelha): Alerta; Fase 2 (laranja): Controle; Fase 3 (amarelo): flexibilização; Fase 4 (verde): Abertura gradual; Fase 5 (azul): Normal controlado; DRS:

Departamento Regional de Saúde.

Fonte: Elaborada por autor com base no Plano São Paulo. 
No primeiro ano da pandemia, logo quando o Governo do Estado de São Paulo tomou a frente da recomendação das medidas no estado e lançou o Plano SP em junho de 2020, alguns casos passaram imediatamente para fase vermelha (caso 16) e a maioria na fase laranja, com medidas que proibiram a abertura de bares, restaurantes, salões de beleza ou academias (fase laranja). Em outros, a pressão surgiu 2 ou 3 semanas depois ( $\operatorname{casos} 8,9,13,18,23,25,26,27)$. A fase vermelha foi determinada para a maior parte dos casos em julho de 2020. A fase laranja deu lugar com o tempo para a amarela em setembro de 2020. Uma nova onda de restrições severas veio em 2021, na segunda onda a partir de janeiro de 2021. Esse período do segundo ano da pandemia está fora da análise em questão, que cobre apenas o primeiro ano da pandemia.

Com a entrada da pandemia e necessidade de resposta e medidas de restrição, governos passaram a demandar serviços e insumos. Com isso surgiram dispensas de licitação, decretos, leis e outros atos relacionados à pandemia, que serão objeto de análise.

\subsection{Coleta de dados}

\subsubsection{Entrevistas}

As entrevistas foram realizadas em duas fases. A primeira fase ocorreu entre janeiro e fevereiro de 2020 e foram realizadas oito entrevistas piloto, duas presencialmente e seis por telefone, com duração média de 40 minutos.

Os respondentes autorizaram que as entrevistas fossem gravadas e transcritas. Os entrevistados eram responsáveis pela administração financeira e/ou contábil das prefeituras que compõem a amostra desta pesquisa. A opção por entrevistar estes respondentes foi em razão de estes possuírem uma visão global de todo o processo de contratação dos seus respectivos municípios. Outro fator que favoreceu a escolha de tais respondentes foi que o setor onde atuam (contábil/financeiro) recebe dados de outros departamentos chave da prefeitura (departamento pessoal, tributação, almoxarifado, patrimônio, compras, licitações etc).

As entrevistas realizadas foram do tipo semiestruturada pois estas fornecem informações detalhadas e profundas da perspectiva de um insider e ainda permitem aos entrevistados especificarem algo que eles conhecem bem (Leech, 2002). O protocolo destas primeiras entrevistas cobriu: (i) processo de integração dos dados entre os diversos sistemas do município; (ii) dificuldades e desafios encontrados no processo de 
implantação dos sistemas; (iii) solicitações de melhorias nos sistemas; (iv) processos internos antes da implantação dos sistemas; (v) possibilidade de ajustes na parametrização dos sistemas; (vi) divulgação de informações nos portais de transparência; (vii) opinião sobre governos abertos e transparência.

Na segunda fase, ocorrida entre setembro de 2020 e março de 2021, o presente estudo realizou outras 24 entrevistas semiestruturadas por telefone ou aplicativos de videoconferência com duração média de 52 minutos. Nesta segunda fase, além de contadores de prefeituras e responsáveis pelas compras da prefeitura, foram entrevistados outros interessados na divulgação de informações públicas (Rowley, 2011) como, sindicalistas, presidentes de câmaras municipais, representantes da imprensa e membros de organizações sociais. As organizações sociais abordadas nas entrevistas são entidades sem fins lucrativos com o propósito de monitorar os gastos públicos visando a eficiência da gestão pública.

O objetivo das entrevistas da segunda fase foi captar os paradoxos e a dinamicidade da publicização de dispensas de licitações e serviços terceirizados por meio de tensões, contradições e dilemas que surgiram nas falas dos respondentes. O protocolo das entrevistas abrangeu questões como: (i) descrição dos procedimentos de lançamentos no sistema de compras; (ii) problemas com publicações de documentos em mídias e divulgação de dados nos portais de transparência; (iii) opinião sobre terceirização de serviços públicos; (iv) problemas associados à folha de pagamento e mão de obra terceirizada; (v) opinião sobre transparência; (vi) opinião sobre dispensa de licitação; (vii) evolução da transparência; (viii) efeito da pandemia na transparência. 
Tabela 3. Respondentes acessados

\begin{tabular}{|c|c|c|c|}
\hline CASOS & ENTIDADE/SETOR & Data & DURAÇÃO (min) \\
\hline 1 & Prefeitura/Contabilidade & $01 / 2020$ & 129 \\
\hline 11 & Prefeitura/Contabilidade & $01 / 2020$ & 35 \\
\hline 10 & Prefeitura/Contabilidade & $01 / 2020$ & 32 \\
\hline 15 & Prefeitura/Contabilidade & $01 / 2020$ & 24 \\
\hline 19 & Prefeitura/Contabilidade & $01 / 2020$ & 64 \\
\hline 11 & Prefeitura/Contabilidade & $01 / 2020$ & 10 \\
\hline 9 & Prefeitura/Contabilidade & $02 / 2020$ & 15 \\
\hline 5 & Prefeitura/Contabilidade & $02 / 2020$ & 21 \\
\hline 19 & Prefeitura/Contabilidade & $09 / 2020$ & 51 \\
\hline 1 & Prefeitura/Contabilidade & $09 / 2020$ & 61 \\
\hline 17 & Prefeitura/Contabilidade & $09 / 2020$ & 59 \\
\hline 9 & Prefeitura/Contabilidade & $09 / 2020$ & 71 \\
\hline 8 & Prefeitura/Contabilidade & $10 / 2020$ & 59 \\
\hline 14 & Prefeitura/Contabilidade & $10 / 2020$ & 40 \\
\hline 20 & Prefeitura/Contabilidade & $10 / 2020$ & 55 \\
\hline 28 & Prefeitura/Contabilidade & $10 / 2020$ & 59 \\
\hline 27 & Prefeitura/Contabilidade & $10 / 2020$ & 60 \\
\hline 10 & Sindicato & $02 / 2021$ & 75 \\
\hline 16 & Sindicato & $02 / 2021$ & 31 \\
\hline 5 & Câmara Municipal & $02 / 2021$ & 17 \\
\hline 12 & Câmara Municipal & $02 / 2021$ & 54 \\
\hline 22 & Câmara Municipal & $03 / 2021$ & 46 \\
\hline 14 & Câmara Municipal & $03 / 2021$ & 34 \\
\hline 1 & Imprensa & $03 / 2021$ & 33 \\
\hline 29 & Prefeitura/Compras & $03 / 2021$ & 34 \\
\hline 7 & Imprensa & $03 / 2021$ & 33 \\
\hline 20 & Prefeitura/Compras & $03 / 2021$ & 24 \\
\hline \multicolumn{4}{|c|}{$\begin{array}{l}\text { ENTREVISTAS } \\
\text { COMPLEMENTARES }\end{array}$} \\
\hline A & Organização Social & $03 / 2021$ & 45 \\
\hline $\mathrm{B}$ & Organização Social & $03 / 2021$ & 61 \\
\hline $\mathrm{C}$ & Imprensa & $03 / 2021$ & 63 \\
\hline $\mathrm{C}$ & Imprensa & $03 / 2021$ & 102 \\
\hline $\mathrm{D}$ & Organização Social & $03 / 2021$ & 75 \\
\hline TOTAL & & & 1572 \\
\hline
\end{tabular}

Fonte: Elaborada pelo autor

Nota 1: Em alguns municípios (casos) ocorreram entrevistas com entidades/setores diferentes.

Nota 2: Cada letra das entrevistas complementares representa municípios que não compõem a amostra.

Nota 3: As duas entrevistas " $C$ " foram realizadas com jornalistas e meios de comunicação diferentes.

Ao todo, o presente estudo realizou 32 entrevistas totalizando 1.572 minutos com duração média de 49 minutos. Todas as entrevistas foram gravadas e transcritas. Além disso, o projeto de pesquisa deste estudo foi aprovado por um Comitê de Ética em Pesquisa da universidade vinculada. 
Figura 2. Fluxograma da coleta de documentos e entrevistas

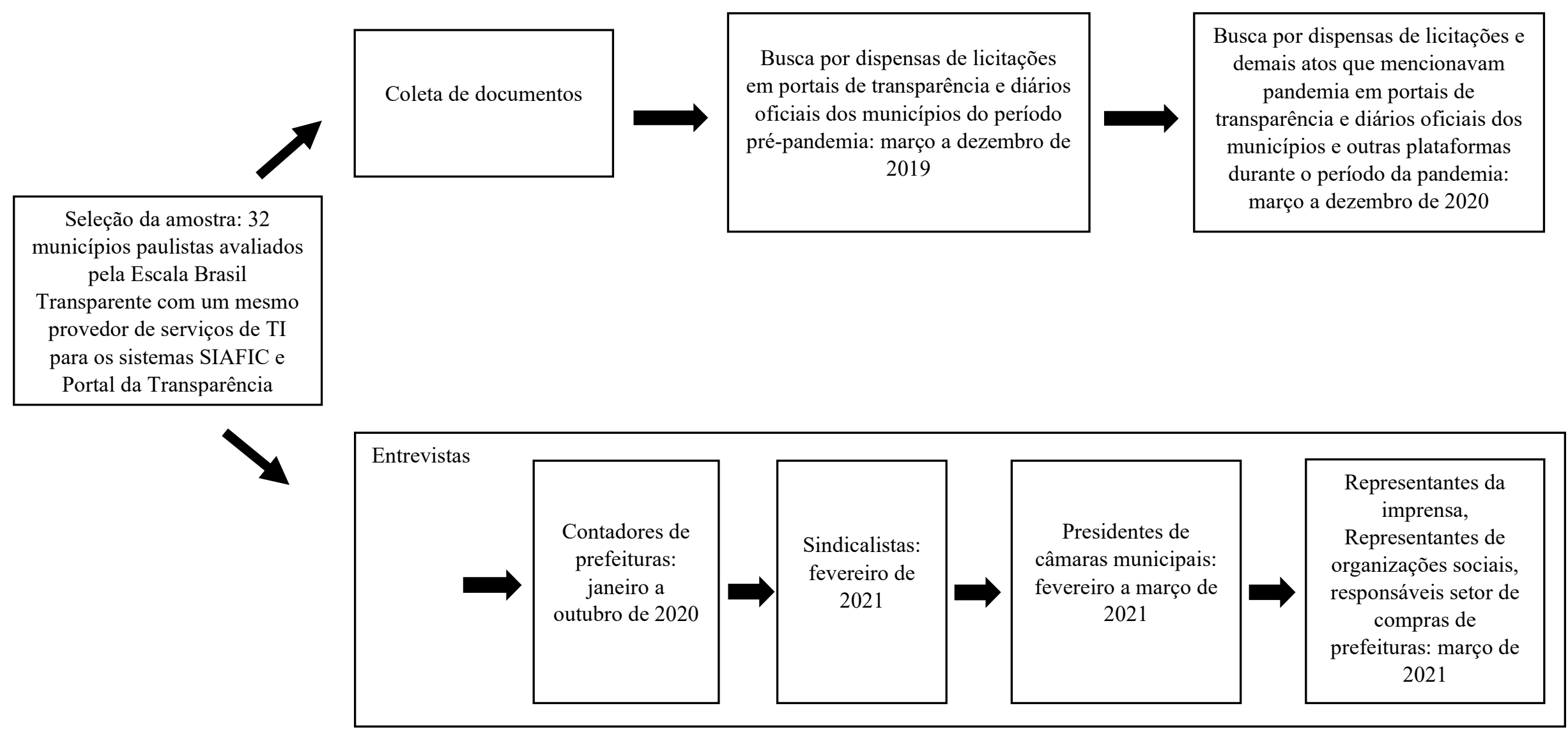

Fonte: Elaborado pelo autor. 


\subsubsection{Atos de contratação e seus documentos}

Com o início da pandemia, a pesquisa coletou vários comunicados por governos dos casos em análise nos seus canais oficiais. O estudo identificou mais de 2500 documentos divulgados por governos de março de 2020 a dezembro de 2020. A pesquisa também identificou 20 tipos de documentos sendo que estes apresentaram 19 finalidades diferentes. Tais documentos encontrados afetavam a população local, alunos da rede municipal, servidores municipais, fornecedores da prefeitura, licitantes, candidatos de concursos/processos seletivos, empresas e hospitais locais. Boa parte dos prefeitos dos casos decretaram estado de emergência ou calamidade pública e outras ações. Como explicado pela Agência Senado (2019), “O estado de emergência se caracteriza pela iminência de danos à saúde e aos serviços públicos. Já o estado de calamidade pública é decretado quando essas situações se instalam”. A decisão de qual adotar cabe ao prefeito. Os tipos, as finalidades e a quantidade dos atos podem ser vistos na Tabela 7 - Apêndice C.

A pesquisa analisou especificamente os atos de contratação, ou seja, as dispensas de licitações encontradas. A análise das dispensas de licitações antes e durante a pandemia possibilitou verificar se este tipo de processo de contratação também iria alterar o comportamento em relação à transparência dos governos no período do regime de exceção. A pesquisa realizou coletas em dois períodos: (i) período pré-pandemia de março de 2019 a dezembro de 2019; (ii) durante a pandemia entre março de 2020 e dezembro de 2020. Estes períodos foram escolhidos para comparação pois a pandemia teve início em março de 2020 e os mandatos dos prefeitos terminaram em dezembro de 2020.

Para acompanhar o desenvolvimento das etapas dos processos de contratações e a publicação dos respectivos documentos, os stakeholders têm a opção de fazê-lo por meio do acesso aos websites das prefeituras. Os documentos que devem ser publicados em qualquer uma das fases, podem ser encontrados nos endereços eletrônicos dos municípios em tópicos referentes às Licitações e Contratos e/ou nos Diários Oficiais Eletrônicos. Normalmente, os documentos publicados são encontrados em arquivos digitais nos formatos de imagens (.pdf) ou texto (.doc). No entanto, informações específicas da execução orçamentária como, empenhos, liquidações e pagamentos podem ser encontrados nos portais de transparência. 


\subsubsection{Período da pandemia de março de 2020 a dezembro de 2020}

Com a pandemia, a pesquisa passou a observar os atos de contratação de insumos e serviços, especificamente as dispensas de licitação em regimes de exceção à legislação que rege a administração pública, implantados por decretos de emergência e calamidade. Tais decretos abrem um regime de exceção sobretudo para a regulação de contratação, mas que não deveria afetar as práticas de transparência e controle, pois estas não foram relaxadas. Então, a pesquisa fez um acompanhamento dos atos de contratação dos casos e os documentos publicados relativos a cada ato.

A busca pelos atos foi realizada nos websites das prefeituras, diários oficiais eletrônicos (DOE's) e portais de transparência. Não foram encontrados diários oficiais para quatro municípios entre os casos analisados. Para esses a pesquisa levantou publicações dos atos no tópico "Notícias" do website da prefeitura ou em rede social (Facebook). Já nos portais de transparência, foram levantadas as dispensas de licitações em dois tópicos: "Licitações"; "Contratos".

A pesquisa utilizou como parâmetro o início da pandemia em março de 2020 e o término dos mandatos dos prefeitos em dezembro de 2020. Este período foi escolhido porque em 2021 poderia ocorrer troca de administração nos municípios estudados. Além disso, a pesquisa comparou o ano de 2020 com o ano anterior à pandemia, para isso foram levantadas as dispensas de licitações realizadas no mesmo período do ano de 2019. Um dos propósitos dessa comparação é observar a dinamicidade da publicização das dispensas de licitações antes e durante a pandemia em 2020 no Estado de São Paulo. Mais detalhes do levantamento desses documentos podem ser consultados no Apêndice C.

\subsubsection{Período pré-pandemia de março a dezembro de 2019}

Para comparar o comportamento da dispensa de licitação na transparência do ato de cada município, a pesquisa levantou contratações no período anterior à pandemia. $\mathrm{O}$ objetivo da comparação era saber o grau de transparência daqueles atos no mesmo município antes de o regime de exceção que se instalaria em 2020 decorrente da pandemia.

A pesquisa buscou nos websites dos municípios por documentos digitais referentes as dispensas de licitações. Nesta etapa, o site da prefeitura era acessado e 
buscava-se algum tópico ou menu relacionado ao portal da transparência. Dentro desse tópico, a pesquisa realizou tentativas de localizar as dispensas de licitações abertas no exercício de 2019.

Após a localização das dispensas de licitações, a pesquisa também realizou buscas nos diários oficiais eletrônicos dos municípios com o objetivo de verificar outros documentos referentes aos processos dispensados de licitação. A verificação da publicação desses documentos é importante para comparar se um mesmo processo é publicado em plataformas diferentes ou não.

\subsection{Tratamento dos dados e evidências}

O processo de realização das entrevistas foi seguido pela transcrição das mesmas. A pesquisa utilizou o sistema de transcrição GAT 2, cujo significado é Gesprächsanalytisches Transkriptionssystem (sistema de transcrição de discurso e análise de conversação) (Selting, M.; Auer, P.; Barth-Weingarten; D., Bergmann, J.; Bergmann, P.; Birkner, K.; et al., 2011). O GAT 2 registra os diálogos e interações naturais do dia-a-dia (Selting et al. 2011) e oferece condições suficientes para a análise de conteúdo de entrevistas relacionadas às ciências sociais (Kowal \& O’Connell, 2014).

As entrevistas foram tratadas por meio da análise de conteúdo com o objetivo de tirar conclusões de maneira lógica, a partir da compreensão de uma mensagem/indicador recebido (Bardin, 2006). Os procedimentos da análise de conteúdo possuem legitimidade entre os métodos qualitativos e rigor científico que contribui para o desenvolvimento de estudos organizacionais (Mozzato \& Grzybovski, 2011). Além disso, o conjunto de técnicas e procedimentos da análise de conteúdo podem ser adaptados para analisar o significado de qualquer tipo de mensagem/indicador escrito ou falado (Bardin, 2006).

Para dar suporte à compreensão das entrevistas, a análise do conteúdo considerou o contexto do fenômeno, seus participantes e a base teórica (Moraes, 1999). O contexto considerado envolveu as questões relacionadas com a transparência pública e a terceirização de serviços públicos antes e durante a pandemia da Covid-19. Como participantes do fenômeno foram considerados os diversos interessados em informações públicas como: agentes públicos, sindicalistas, órgãos fiscalizadores, organizações sociais e cidadãos. Enquanto que como base teórica, a pesquisa utilizou a Teoria do Paradoxo. 
O processo da análise de conteúdo foi realizado por meio de cinco etapas: preparação das informações; transformação do conteúdo em unidades; classificação das unidades em categorias; descrição; interpretação (Moraes, 1999).

Na etapa da preparação foram identificados os trechos das entrevistas que estavam de acordo com o objetivo da pesquisa. Portanto, a identificação focou nas falas que abordavam questões associadas aos efeitos da pandemia na transparência de informações públicas. A etapa seguinte transformou o conteúdo dos trechos identificados em unidades, ou seja, as falas selecionadas foram individualizadas e divididas em elementos menores por meio de uma codificação inicial. Assim, a divisão das falas propiciou a criação de códigos como: disponibilização e compreensão de dados públicos; forma como cada interessado nos dados se posiciona; relação entre os interessados; práticas de condutas inapropriadas; dinâmicas de processos; dificuldades para divulgar dados.

Em seguida, a etapa da classificação das categorias agrupou os trechos identificados e codificados considerando as semelhanças e partes comuns existentes entre eles. Nessa etapa, foram utilizados critérios semânticos que criaram categorias temáticas como: Estar e não ser; ver e não enxergar; tensão/pressão; corrupção; dinamicidade/evolução; cultura; estrutura de pessoal/organizacional. Na etapa seguinte, a descrição apresentou textos resumidos (seção 7) com o propósito de mostrar os significados das falas analisadas. Por fim, a etapa da interpretação considerou todo o conteúdo, explícito ou latente, e buscou compreendê-lo com o objetivo de oferecer uma contribuição teórica. 


\section{CONTRATAÇÃO, PUBLICIZAÇÃO E PANDEMIA}

A contratação de serviços e insumos pelo setor público segue várias normas que disciplinam etapas do processo de compra e a publicização dos seus respectivos atos e documentos. Dentro das etapas do processo de compra ocorrem procedimentos que avaliam as propostas e a documentação dos licitantes bem como a homologação do processo que deve ser realizada pela autoridade responsável do órgão. Algumas das etapas dos processos de compras podem gerar documentos como o edital, o termo de homologação e o extrato do contrato que devem ser publicizados em algum jornal ou diário oficial. Com o advento da pandemia surgiram outras normas que causaram um regime de exceção e permitiram que órgãos públicos entrassem em estado de emergência ou calamidade. Assim, os processos de contratações e publicizações do setor público foram impactados por este regime de exceção.

\subsection{Estágios, fases da licitação e a publicização de documentos}

Apesar de a pesquisa ter a divulgação de atos de dispensa de licitação como uma das unidades de análise, esta seção apresentará o processo licitatório de forma geral. É importante apresentar o processo licitatório como um todo para que seja esclarecido como a dispensa de licitação é menos burocrática do que as demais modalidades de licitação. A elaboração e divulgação de alguns documentos como o edital e a homologação não são necessários nas dispensas de licitações pois este tipo de processo visa agilizar as contratações.

O processo de contratação pode ser observado em dois estágios: (i) pré-execução orçamentária, (ii) execução orçamentária (mais detalhes no Apêndice C). Em cada um desses estágios existem fases (interna, externa e contratual) e etapas (planejamento, abertura, habilitação, julgamento, adjudicação, homologação e execução do contrato). Sendo que tais etapas são compostas por documentos que devem ser publicados ou não conforme as normas exigidas. A publicação desses documentos é necessária para que os diversos interessados acompanhem o andamento de todo o processo. Neste estudo, as

publicações são entendidas como os documentos exibidos nos Diários Oficiais Eletrônicos dos Municípios, enquanto que as disponibilizações são compreendidas como os documentos apresentados em portais de transparência e demais plataformas digitais. Portanto, além da publicação de documentos, também foram observados dados 
disponibilizados nos Portais de Transparência dos municípios estudados. Também não é propósito do estudo explicar os pormenores das legislações pertinentes ao tema.

No estágio da pré-execução orçamentária ocorrem as fases interna e externa, enquanto que no estágio da execução orçamentária existe a fase contratual. $\mathrm{Na}$ fase interna (pré-execução orçamentária), ocorre a geração de documentos (três orçamentos prévios do objeto pretendido; consulta para verificação de dotação orçamentária; resposta à consulta para verificação de dotação orçamentária; justificativa; e parecer jurídico) que não precisam ser publicados. Nesta fase, ocorre a etapa do planejamento, ou seja, são desenvolvidos os estudos e a elaboração do edital antes que este seja formalizado e publicado (Jordão, 2014).

$\mathrm{Na}$ fase externa, ocorre o início da exigência de publicação de documentos que expõem informações sobre datas, objetos a serem contratados, alterações do processo licitatório ou apresentação de recurso. A fase externa é constituída por cinco etapas (abertura, habilitação, julgamento, adjudicação e homologação) realizadas pela Comissão de Licitações e/ou pelo Pregoeiro com o objetivo de selecionar a proposta mais vantajosa para a administração pública (Del Luca \& Bender Filho, 2016). Na etapa de abertura, a legislação exige a publicação dos seguintes documentos: resumo do edital, modificações ao edital, anulação ou revogação do edital (Rigolin, 2016). Nas etapas seguintes (habilitação, julgamento, adjudicação e homologação) há a exigência de publicação quando algum licitante entra com a interposição de recurso para cada uma das etapas citadas (Rigolin, 2016). Na fase externa, também há a geração de documentos que não precisam de publicação. O conteúdo de tais documentos contém outros detalhes sobre as regras e procedimentos do processo licitatório.

Segundo o Decreto $N^{\circ} 10.024 / 2019$, que regulamenta as licitações na modalidade pregão, o edital completo deve ser disponibilizado em meios eletrônicos como websites de prefeituras. O conteúdo deste documento precisa conter itens importantes que são alvo da fiscalização dos Tribunais de Contas. Tais itens são apresentados como anexos e precisam trazer detalhamentos e especificações para que proporcionem um certame justo e evite questionamentos e disputas que possam causar danos ao erário. A legislação estabelece nomenclaturas diferentes para esses itens conforme a modalidade de licitação. Um primeiro item traz especificações de como o serviço deverá ser prestado e é chamado Termo de Referência (Pregões), enquanto que em outras modalidades de licitações, o item é denominado Projeto Básico. Em alguns editais encontrados, este item era apresentado 
como Especificações do Objeto. Um segundo item traz as condições do acordo entre as partes e é apresentado como Minuta do Contrato ou Ata de Registro de Preços. Durante a coleta de dados foi observada a ausência do Termo de Referência, Projeto Básico ou documentos equivalentes em alguns processos de contratação que possuíam editais.

A fase contratual, marca o início do estágio da execução orçamentária e da execução dos serviços a serem prestados. A publicação dos documentos desta fase apresenta o resumo do contrato, suas possíveis alterações ou aplicação de penalidades. Segundo a legislação pertinente, os documentos desta fase que devem ser publicados são os seguintes: extrato do contrato, aditamentos contratuais, rescisão do contrato, imposição de penalidade e resultados dos recursos (Rigolin, 2016). Os documentos desta fase, cuja publicação não é exigida pela legislação, contêm as seguintes informações: detalhes das condições acordadas entre as partes; dados sobre execução do contrato e pagamentos.

As pessoas, empresas e organizações podem se interessar pelo conteúdo destes documentos que são divulgados em mídias eletrônicas ou impressas. Rowley (2011), em seu estudo sobre stakeholders em e-governments destaca com precisão quem são os principais interessados nas informações divulgadas pelos governos: pessoas usuárias de serviços; cidadãos; companhias; pequenas e médias empresas; gestores públicos (servidores); outras agências governamentais; organizações sem fins lucrativos; políticos; gerentes de projeto de governo eletrônico; desenvolvedores de TI; fornecedores; pesquisadores e avaliadores. No entanto, as intenções dos stakeholders determinam o interesse em cada tipo de documento (mais detalhes no Apêndice C).

Os cidadãos que participam de atividades de controle social podem se interessar em analisar e/ou fiscalizar alguns documentos das fases do processo de contratação (Araújo \& Doroteu, 2013).

As companhias, pequenas e médias empresas podem participar das licitações e se interessarem pela publicação de todos os documentos de um processo licitatório. Neste caso, as empresas licitantes que não ganham a licitação podem se interessar pela publicação dos documentos da fase contratual porque estas podem aceitar a execução do objeto contratado caso o vencedor não venha a executar o contrato por algum motivo (Rigolin, 2016).

O interesse dos gestores públicos, servidores e políticos nas publicações dos documentos de processos licitatórios pode estar associado às atividades exercidas por tais 
indivíduos (G1, MA, 2021). Tais atividades podem estar associadas à elaboração, execução ou fiscalização dos processos licitatórios.

As agências governamentais fiscalizadoras, como Tribunais de Contas e Ministério Público, naturalmente têm interesse nos documentos publicados em todas as etapas do processo de contratação. Os desenvolvedores de TI podem se interessar pelas etapas dos processos licitatórios para criarem sistemas informatizados destinados aos órgãos públicos. O interesse dos pesquisadores na divulgação de informações públicas pode estar associado ao desenvolvimento de seus respectivos estudos. A publicação das interposições de recursos pode não interessar a todos os stakeholders. Segundo Rigolin (2016), em relação à interposição de recursos, "o universo dos interessados é conhecido e costuma ser pequeno; é certo que não faz muito sentido publicar algo que apenas interessa a, por exemplo, três ou quatro pessoas conhecidas, participantes do processo" (p. 5).

\subsection{Regime de exceção nas contratações}

O regime de exceção causado pela pandemia pode trazer o cenário de emergência ou calamidade nos entes federativos. Este regime de exceção abre uma brecha na legislação ao flexibilizar e agilizar os processos de contratação por meio de dispensas de licitações que contratam materiais e/ou serviços destinados ao combate da pandemia (Luiz, 2020). A flexibilização também ocorre, por exemplo, com a simplificação de termos de referência ou projetos básicos e a dispensa de estimativa de preços. A agilidade também é vista quando o regime de exceção permite a redução de prazos pela metade em licitações da modalidade pregão. Por outro lado, o regime de exceção não flexibilizou ou reduziu a publicização de atos de contratação da administração pública. No caso das publicizações foi exigido ainda que todas as contratações destinadas ao combate da pandemia deveriam ser publicizadas em site oficial específico. A criação destes sites específicos passou a divulgar outros tipos de informações como pacientes internados com Covid-19, número de mortes por Covid-19, pacientes recuperados etc. A Tabela 4 compara os dois cenários. 
Tabela 4. Contratação e publicização em regime de normalidade vs. regime de exceção

\begin{tabular}{|c|c|c|}
\hline & Regime de normalidade & Regime de exceção \\
\hline $\begin{array}{l}\text { Contratação } \\
\text { requerida por lei }\end{array}$ & $\begin{array}{l}\text { * Licitações baseadas na Lei nº 8.666/93 e legislação } \\
\text { complementar } \\
\text { * Dispensa de licitação limitada a determinado valor }\end{array}$ & $\begin{array}{l}\text { * Licitações baseadas na Lei no } 8.666 / 93 \text { e legislação complementar e Lei } n^{\circ} \\
13.979 / 20 \\
\text { * Dispensa de licitações para as contratações de enfrentamento à Covid-19 } \\
\text { * Permissão para contratar empresas com inidoneidade declarada ou com } \\
\text { suspensão no direito de participar de licitação, desde que comprovado que são } \\
\text { as únicas fornecedoras do bem ou serviço a ser adquirido } \\
\text { * Simplificação do processo licitatório com termo de referência ou projeto básico } \\
\text { simplificados } \\
\text { * Dispensa da estimativa de preços } \\
\text { * Celeridade nos pregões com redução de prazos pela metade } \\
\text { * Duração dos contratos com base na Lei no } 13.979 / 20 \text { prorrogáveis enquanto } \\
\text { durar a situação de emergência } \\
\text { * Dispensa de Audiência Pública prévia para contratações com valores superiores } \\
\text { * R } \$ 150 \text { milhões } \\
\text { * Acréscimos ou diminuições dos contratos originados da Lei no }{ }^{\circ} 13.979 / 20 \text { em até } \\
50 \% \text { do valor contratado }\end{array}$ \\
\hline $\begin{array}{l}\text { Publicização } \\
\text { requerida por lei }\end{array}$ & $\begin{array}{l}\text { * Edital } \\
\text { * Homologação } \\
\text { * Ratificação da dispensa } \\
\text { * Extrato de contrato }\end{array}$ & $\begin{array}{l}\text { * Edital } \\
\text { * Homologação } \\
\text { * Ratificação da dispensa } \\
\text { * Extrato de contrato } \\
\text { * Contratações destinadas ao combate da pandemia em site específico }\end{array}$ \\
\hline
\end{tabular}

Fonte: Adaptado de (Luiz, 2020). 
No regime de normalidade, a dispensa de licitação já era prevista pela Lei $\mathrm{N}^{\mathrm{o}}$ 8.666/93 para que os processos de contratações fossem menos morosos (Jesus, 2020) e mais simples (Lima Filho, Martins, \& Peixe, 2021). Após o advento da pandemia, foi sancionada a Lei $\mathrm{N}^{\mathrm{o}} 13.979 / 20$, a qual possibilitou que os processos de contratações por meio das dispensas de licitações destinadas ao combate da Covid-19 ficassem ainda mais flexíveis (Lima Filho, Martins, \& Peixe, 2021). Tal flexibilização foi necessária para que a administração pública adquirisse com urgência os recursos médico-hospitalares para combater a pandemia e garantir o Direito à Saúde e ao Direito à Vida (Jesus, 2020). 


\section{ANÁLISE DA PUBLICIZAÇÃO DURANTE A PANDEMIA}

Em 11/03/2020, a Organização Mundial da Saúde (OMS) declarou a pandemia do novo coronavírus (Sars-Cov-2), causador da doença Covid-19 (Moreira \& Pinheiro, 2020). O Decreto Estadual 64.881 deu início às medidas de quarentena entre o período de 24/03/2020 e 07/04/2020. Posteriormente, o Governo de São Paulo publicou outros decretos que prorrogaram a quarentena. A primeira prorrogação (08/04/2020 a 22/04/2020) foi determinada pelo Decreto Estadual 64.920. A segunda prorrogação (23/04/2020 a 10/05/2020) foi estabelecida pelo Decreto Estadual 64.946.

$\mathrm{O}$ avanço da pandemia do coronavírus fez com que entidades governamentais decretassem estado de emergência e/ou calamidade pública. Como mencionado no tópico anterior, é esperado que ocorra um certo relaxamento do regime de contratação com maior uso das chamadas dispensas de licitação. Observou-se um desencontro de informações na divulgação em Diários Oficiais e o que foi divulgado nos tópicos: "Licitações"; "Contratos" dos portais de transparência dos municípios. Tal desencontro não poderia acontecer, pois uma mesma informação de uma dispensa de licitação deveria ser encontrada nestas três plataformas citadas: Diários Oficiais; e tópicos: "Licitações"; "Contratos".

A Tabela 5 compara os atos anteriores a março de 2020 (antes pandemia), 419 atos com 21\% de divulgação, contra 1109 atos após março 2020, (pós-pandemia). Contudo 280 são relativos às medidas para combate à pandemia (mencionam este termo no objeto) e possuem uma média de divulgação completa de 6\%. Com 17\% de divulgação completa, 829 dispensas de licitação são de outros assuntos.

Tabela 5. Média de divulgação dos atos, antes e durante a pandemia

\begin{tabular}{c|c|c}
\hline Períodos & Qtde. de dispensas & $\begin{array}{l}\text { Média divulgação completa } \\
\text { em pdf. }\end{array}$ \\
\hline Antes da pandemia Objeto: Outros & 419 & $21,72 \%$ \\
\hline Durante a pandemia Objeto: Outros & 829 & $17,61 \%$ \\
\hline Durante a pandemia Objeto: Covid-19 & 280 & $06,00 \%$ \\
\hline Total & 1528 & $16,66 \%$ \\
\hline
\end{tabular}

Fonte: Elaborada pelo autor.

Nota 1: Divulgação completa: dispensas de licitações com contratos disponibilizados em formato pdf.

Nota 2: Antes da pandemia: março a dezembro 2019

Nota 3: Depois sem mencionar Covid-19: março a dezembro 2020

Nota 4: Depois com menção à Covid-19: março a dezembro 2020

Como se pode observar na Tabela 5, a publicização de documentos completos variou de 6 a 21\%. A priori, isso não estaria relacionado com o momento na pandemia, 
mas sim com políticas internas de cada um dos 32 municípios, ou seja, de como o governo lida com os paradoxos que emergem localmente.

A divulgação completa em geral diminuiu, mas não é igual para todos os municípios (casos), como pode ser visto na Tabela 6 que compara os casos, ou seja, as prefeituras estudadas, e mostra se houve aumento ou queda da divulgação por objeto contratado. 
Tabela 6. Queda ou aumento da divulgação por objeto de contrato

\begin{tabular}{|c|c|c|c|c|c|c|c|}
\hline \multirow[b]{2}{*}{ Casos } & \multirow{2}{*}{$\begin{array}{c}\text { Decreto de } \\
\text { emergência } \\
\text { ou } \\
\text { calamidade }\end{array}$} & \multicolumn{3}{|c|}{$\begin{array}{c}\text { Número de dispensas } \\
\text { (\% com divulgação completa) }\end{array}$} & \multicolumn{3}{|c|}{$\begin{array}{c}\text { Variação da transparência } \\
\qquad(\%)\end{array}$} \\
\hline & & $\begin{array}{c}\text { Outros } \\
\text { objetos pré- } \\
\text { pandemia } \\
\text { (a) }\end{array}$ & $\begin{array}{c}\text { Outros } \\
\text { objetos na } \\
\text { pandemia } \\
\text { (b) }\end{array}$ & $\begin{array}{c}\text { Objeto } \\
\text { Covid na } \\
\text { pandemia } \\
\text { (c) }\end{array}$ & $\begin{array}{c}(\mathrm{b} x \\
100 / \mathrm{a}) \\
-100\end{array}$ & $\begin{array}{c}(\mathrm{c} x \\
100 / \mathrm{b}) \\
-100\end{array}$ & $\begin{array}{c}(c x \\
100 / a) \\
-100\end{array}$ \\
\hline & \multicolumn{7}{|c|}{ Casos com redução de divulgação } \\
\hline 6 & Sim & $9(100)$ & $24(87)$ & $4(75)$ & $-13,00$ & $-13,79$ & $-25,00$ \\
\hline 1 & Sim & $12(75)$ & $57(29)$ & $36(19)$ & $-61,33$ & $-34,48$ & $-74,67$ \\
\hline 2 & Sim & $8(38)$ & $24(8)$ & $15(6)$ & $-78,95$ & $-25,00$ & $-84,21$ \\
\hline 17 & Sim & $7(43)$ & $38(7)$ & $11(9)$ & $-83,72$ & 28,57 & $-79,07$ \\
\hline 30 & Sim & $9(33)$ & $41(7)$ & $18(-)$ & $-78,79$ & - & - \\
\hline 28 & Sim & $20(60)$ & $13(-)$ & $5(-)$ & - & - & - \\
\hline 31 & Não & $7(14)$ & $5(-)$ & $31(-)$ & - & - & - \\
\hline
\end{tabular}

Casos com aumento da divulgação

\begin{tabular}{c|c|c|c|c|c|c|c}
\hline 7 & $\operatorname{Sim}$ & $79(45)$ & $81(65)$ & $16(18)$ & 44,44 & $-72,31$ & $-60,00$ \\
\hline 5 & $\operatorname{Sim}$ & $6(-)$ & $18(77)$ & $3(33)$ & - & $-57,14$ & - \\
\hline 26 & $\operatorname{Sim}$ & $4(-)$ & $13(38)$ & $1(-)$ & - & - & - \\
\hline 4 & $\operatorname{Sim}$ & $2(-)$ & $10(30)$ & $0(-)$ & - & - & - \\
\hline 8 & $\operatorname{Sim}$ & $8(-)$ & $85(2)$ & $29(-)$ & - & - & - \\
\hline 29 & $\operatorname{Sim}$ & $20(75)$ & $27(85)$ & $1(-)$ & 13,33 & - & - \\
\hline
\end{tabular}

Casos sem divulgação regular

\begin{tabular}{c|c|c|c|c|c|c|c}
\hline 14 & Sim & $18(-)$ & $15(-)$ & $4(-)$ & - & - & - \\
\hline 16 & Sim & $14(-)$ & $11(-)$ & $13(-)$ & - & - & - \\
\hline 22 & Não & $13(-)$ & $16(-)$ & $0(-)$ & - & - & - \\
\hline 27 & Não & $22(-)$ & $38(-)$ & $5(-)$ & - & - & - \\
\hline 10 & Sim & $29(-)$ & $21(-)$ & $6(-)$ & - & - & - \\
\hline 9 & Sim & NA & $126(-)$ & $33(-)$ & - & - & - \\
\hline 12 & Sim & $29(-)$ & $31(-)$ & $0(-)$ & - & - & - \\
\hline 23 & Sim & $17(-)$ & $6(-)$ & $0(-)$ & - & - & - \\
\hline 15 & Sim & $14(-)$ & $16(-)$ & $1(-)$ & - & - & - \\
\hline 20 & Não & $23(-)$ & $28(-)$ & $15(-)$ & - & - & - \\
\hline 32 & Sim & $12(-)$ & $14(-)$ & $0(-)$ & - & - & - \\
\hline 3 & Sim & $12(-)$ & $10(-)$ & $1(-)$ & - & - & - \\
\hline 25 & Sim & $9(-)$ & $0(-)$ & $0(-)$ & - & - & - \\
\hline 19 & Sim & $8(-)$ & $30(-)$ & $16(-)$ & - & - & - \\
\hline 13 & Sim & $3(-)$ & $1(-)$ & $0(-)$ & - & - & - \\
\hline 11 & Sim & $2(-)$ & $10(-)$ & $0(-)$ & - & - & - \\
\hline 18 & Não & $2(-)$ & $15(-)$ & $12(-)$ & - & - & - \\
\hline 21 & Não & $1(-)$ & $2(-)$ & $2(-)$ & - & - & - \\
\hline 24 & Não & $0(-)$ & $3(-)$ & $1(-)$ & - & - & - \\
\hline Total & & $419(21)$ & $829(17)$ & $280(6)$ & $-19,05$ & $-64,71$ & $-71,43$ \\
\hline Fonte: El & & & & & - \\
\hline
\end{tabular}

Fonte: Elaborada pelo autor 
Apenas 13 disponibilizaram documentos completos. Desses 13 casos, uns disponibilizaram mais documentos completos do que outros. Entre esses 13 casos, o fato de um município disponibilizar mais documentos completos do que outros também pode estar relacionado com práticas de políticas internas.

Na Tabela 6 é possível observar que no caso 7 ocorreu um aumentou da divulgação completa de $45 \%$ das 79 dispensas em 2019 para 65\% das 81 dispensas que não mencionam pandemia em 2020. No entanto, neste caso 7, ao observar a divulgação completa das dispensas que mencionam a pandemia o percentual cai para $18,75 \%$. O caso 1 acompanhou a tendência de diminuição da divulgação completa. Esse caso 1 em 2019 tinha um percentual de divulgação completa de 75\%, enquanto que em 2020 os percentuais caíram para 29\% (não menciona pandemia) e 19\% (menciona pandemia).

Na maioria dos casos a transparência é nula, antes ou durante a pandemia, para objetos associados à Covid-19 ou não. Nestes casos a prática da divulgação de dispensas de licitação já era baixa (casos sem divulgação regular), apesar de usarem dispensas de licitação como prática. Em dois casos em que houve aumento de divulgação (pois em 2019 a divulgação era nula) apesar do aumento, a divulgação de contratos associados à Covid-19 era menor que dispensas de outros assuntos. No caso 29, apesar do aumento da transparência para outro objeto, quando envolveu Covid-19 a divulgação foi nula.

Efeito similar ocorreu com outros 4 casos, com a redução da transparência apara todos tipos de dispensa, Covid-19 e outros assuntos. 


\section{PARADOXO SOBRE ABERTURA DE GOVERNOS E O EFEITO DA PANDEMIA}

O relaxamento da regulação de contratação pode ter afetado como prefeitos e servidores interpretaram a regulação de transparência, que não havia sido flexibilizada pelo regime de exceção. As práticas de divulgação de contratos por um lado podem ser pressionadas pelo benefício de manter uma conveniente opacidade da contratação, por outro por cumprir a regulação de transparência e pelo controle social e da mídia que se beneficiam e cobram transparência dos atos públicos.

As tensões mencionadas expõem os dois pólos de um paradoxo opacidade $v s$. transparência. Agentes públicos podem se posicionar mais no pólo da opacidade por interesses próprios ou de terceiros para reduzir a divulgação dos processos de contratações. Ou se direcionar para o pólo da transparência atendendo normas e pressões dos demais interessados nas informações públicas. Enquanto a sociedade, mídia e Tribunais de Contas cobrando a regulação aplicada poderiam forçar os agentes públicos a ampliar a publicidade nos atos das contratações, outros interesses poderiam incentivar a redução da transparência. Entre estes outros interesses estão desde atos ilícitos, quanto uma expectativa de que cortando as atividades associadas à divulgação aumentaria a agilidade dos atos ou economia de esforços em um momento de sobrecarga administrativa da crise. As razões serão exploradas a seguir.

Importante notar que em um mesmo município, a posição no paradoxo pode mudar com o tempo e para tipos de transação, ou mesmo para transações similares dependendo do contexto associado. Como visto no item anterior, existem variações de transparência dentro do mesmo município, porém as tensões do paradoxo estão presentes.

Antes da pandemia, existia um equilíbrio alcançado dentro de cada governo municipal, decorrente das práticas já estabelecidas e do governo eleito para aquele mandato. Com o advento da pandemia, a possibilidade e necessidade de agilidade nos atos de contratação em resposta à pandemia, além de outros possíveis benefícios e interesses não declarados, levou governos a decretarem os estados de emergência e/ou calamidade.

A necessidade de agilizar os atos de contratação para combater a pandemia mostrou-se positivo ao evitar processos mais burocráticos. No entanto, a agilidade das contratações por meio das dispensas de licitações apresentou um aspecto negativo em 
relação à transparência. Tal aspecto negativo altera o equilíbrio do paradoxo nos governos municipais de modo que o paradoxo fique mais próximo do pólo da opacidade. Em razão disso, agentes públicos podem interpretar a dispensa de licitação como uma forma de contratação urgente que reduz exigências de publicizar informações ex ante, sendo que a norma pede que os dados sejam publicados ex post.

Esta opção de contratar dispensando a licitação é menos transparente pois tal ato só é publicado após o início do objeto contratado. Assim, a pandemia fez com que o equilíbrio do paradoxo nos governos municipais ficasse mais próximo do pólo da opacidade.

\subsection{Entendimento da transparência antes e durante a pandemia}

A transparência tem sido tratada como sinônimo de presença de informação nos portais de transparência, inclusive em estudos acadêmicos (Dias, Aquino, Silva, \& Albuquerque, 2020). Mas a presença de canais de informação bloqueados, o questionamento da veracidade da informação e a dificuldade de compreender dados na forma como são divulgados podem estar mais associados ao pólo da opacidade.

Informantes relatam que a informação, apesar de estar disponível, não é transparente pois não são compreensíveis para interessados que acessam dados públicos. Os relatos são de que usuários acessam informações, mas não entendem a informação que está disponível. Assim, a divulgação por si só não é suficiente para que usuários possam usá-la. O layout e o conteúdo dos portais de transparência são formatados visando atender a legislação, ao invés de proporcionar informação compreensível para os diversos usuários. Até mesmo usuários mais experientes como membros de organizações sociais apontaram dificuldades em encontrar e entender as informações publicizadas (Leite Filho, Colares e Andrade, 2015; Wang \& Shepherd, 2019). A seguir, são apresentados trechos das falas dos entrevistados que demostram a questão de a informação estar disponível, mas não ser compreensível e/ou acessível.

\footnotetext{
"portais de transparência mal elaborados, portais de transparência que na verdade dão uma passada de pano no problema, né? Que na verdade são mais dificultosos do que transparentes a bem da verdade, né? Informações que estão lá, mas que não são acessíveis... É difícil você falar para uma pessoa para um leigo no assunto, né? - Organização Social - D

"O que é ruim muitas vezes e isso nós já pontuamos aqui é que às vezes, a transparência não é dada, não é feita da forma correta, né? Ai você cria um problema ao invés de criar uma solução." - Organização Social - D
} 


\begin{abstract}
"Muito precário e inacessivel, a grande maioria não tem acesso e quando uma outra acessa as informações para tentar compreender, acaba não entendo."Sindicato - Caso 16

"quem trabalha na contabilidade, o portal da transparência é molezinha, agora talvez pra quem não trabalha fica, talvez alguns dados fica mais dificil de ver. Mas também tem o, a pessoa pode vir, o acesso à informação, ela pode perguntar para a prefeitura o que quiser e ai a prefeitura vai responder, né? Porque talvez a pessoa não entende lá no portal, mas ela fazendo o requerimento no portal ou se não aqui mesmo presencial aqui." - Prefeitura - Caso 14

"De repente, se fosse de mais fácil entendimento, as pessoas se sentissem mais motivadas porque elas iriam entrar lá e iria ver, clicar no botãozinho e ver tudo o que ela queria e não é bem assim, a gente sabe." - Prefeitura - Caso 27

"Era um contrato que envolvia aproximadamente muitos postos de serviço. ( ) são funcionários nomeados, não nomeados ( ) contratações que não eram submetidas à transparência pública. Então, você faria o contrato, o contrato () tinha ciência do que previa, mas você não sabia como ele estava sendo executado. Então, que tipo de pessoa estava sendo contratada nessa parceirização? ( ) contratado sem concurso público, sem processo seletivo." Imprensa - C
\end{abstract}

Os servidores têm uma perspectiva de que a informação está completa e disponibilizada, alguns não enxergam que podem estar incompletas, inacessíveis ou incompreensíveis para os demais usuários. O conhecimento técnico e a constante utilização do sistema informatizado de gestão pública parecem impedir que contadores e demais servidores vejam as dificuldades encontradas pelos usuários externos de informações. Para contadores e demais servidores, os portais de transparência estão em perfeitas condições e não precisam de melhoramentos. Por outro lado, usuários externos expõe uma visão totalmente contrária à dos servidores públicos. Estes usuários externos criticam a maneira como as informações são disponibilizadas nos portais de transparência.

\footnotetext{
"Está tudo no portal. Tudo, tudo, tudo, tudo. Tudo que é covid hoje, se você entrar no portal do município, tudo, tudo que é covid, você vai ter a informação clarinha lá. Decretos, leis, portarias que alteraram, leis que mandaram fechar, leis que mandou abrir comércio, leis que mandou abrir academia, leis que mandou fechar, né? - Prefeitura - Caso 17

“...inclusive agora ( ) covid ai tem até um especial pra covid, mas é tudo, você parametrizou aqui, vai automático, você não precisa ficar fazendo manual, então é por isso que se a pessoa souber consultar, tem tudo ai.." - Prefeitura Caso 14

"Hoje tem tudo lá, tem decreto, tem relação se contratou pessoas, tem tudo isso ai lá, né? Tem receita, despesa, licitação, contrato, entendeu? Conforme o Tribunal e o Ministério Público ia exigindo ( ) desenvolver para poder atender os dois, Tribunal de Contas e Ministério Público. Então, hoje tem. ( ) tudo que
} 
é ligado ao covid tem um canto específico dentro do portal." - Prefeitura - Caso 8

"Ficou uma aba dentro do portal, só que com as informações todas bagunçadas faltando informações, uma assimetria de informações muito grande, né? Você não conseguia saber para onde estava indo aquele, de onde estava vindo aquele recurso, se era recurso da saúde, se era recurso do Estado, se era recurso do governo federal, enfim, faltavam diversas coisas. Basicamente, jogavam ali, né?" - Organização Social - D

De forma similar a veracidade da informação divulgada também é questionada e ao menos parte dos atores não confia plenamente que o divulgado representa fielmente a transação (Klein, Klein, \& Luciano, 2018). Neste caso, a seguir um ator externo à prefeitura, representante de câmara municipal, argumenta que o dado divulgado não é garantia de que ele seja real.

"Não tem como ser melhorado na transparência se não melhorar quem está
atrás da cadeira, entendeu? Porque a transparência () ela é divulgada, mas
ela é divulgada do jeito que foi feito nos bastidores. A divulgação é importante,
a pessoa vai ter o conhecimento, mas como eu disse antes. Como é que eu vou
saber que aquilo que está colocado lá no portal da transparência é o real, é
verdadeiro? Então, a divulgação já é, já foi uma melhora, entendeu? Publicar,
colocar no portal da transparência." - Câmara Municipal - Caso 12

Já um membro de uma organização social argumenta que para confirmar a veracidade de uma informação é necessário aprofundar a análise e solicitar documentos físicos.

“...muitas vezes, é que o que está divulgado ali nem sempre corresponde à realidade dos fatos. Muitas vezes, o cidadão tem ainda que recorrer à busca do processo físico nas prefeituras para comparar esses dados, o que torna bastante trabalhoso para o cidadão que normalmente ele é voluntário, ele não recebe para trabalhar no observatório e tem os seus afazeres no dia a dia." Organização Social - A

Apesar de os governos parecerem abertos, estes não são totalmente acessíveis. Embora os governos permitem algum acesso, para certos assuntos colocam barreiras para que a sociedade "participe" e/ou "observe" o governo "por dentro". Parece ser uma abertura seletiva. Por exemplo, governos disponibilizam canais como sistema eletrônico do serviço de informação ao cidadão (e-sic) e portais de transparência, mas não são efetivamente empregados. Ainda, obstáculos encontrados em canais como o e-sic desestimulam organizações sociais e sociedade a fiscalizar a administração pública. 
"Principalmente com transparência ativa, né? Coisas que você se quer precisaria pedir pela LAI porque se trataria de transparência ativa, né? E você tem que ficar batendo na porta do executivo ou do legislativo toda hora com pedido de acesso à informação para que aquela informação seja disponibilizada para você." - Organização Social - D

"O problema no caso da câmara (município da entrevista complementar C) é que eles exigiam uma espécie de cadastro prévio para você ter acesso à informações da transparência ativa, ou seja, ( ) portal de transparência. Então, aí, isso é uma barreira para algo que deveria ser de livre acesso." - Imprensa $\mathrm{C}$

"E se a pessoa tem um certo conhecimento técnico, né? Ela acaba encontrando a informação, a informação não é omitida ( ), ela não é omitida, mas eu vou dar um exemplo, se você chegar num portal num portal de transparência que adota um sistema que adota aqui em (município da entrevista complementar B), por exemplo, chega no portal da transparência e tiver que consultar uma despesa e depois quiser ter acesso ao contrato ( ) sair daquele programa, ir para outro e depois voltar para continuar a conferência, isso dificulta demais," - Organização Social - B

A dificuldade de acesso e de controle social também se mostra nas constantes alterações na organização de dados nos portais de transparência. $O$ interessado em informações públicas precisa descobrir por conta própria outros meios de acessar uma informação deslocada de sua posição original.

"E eu lembro assim, claramente de entrar numa aba de acesso da prefeitura, eu acho que era da secretaria de administração, estar visivel a opção 'Dispensa de Licitação' e acho que ( ) mexendo ( ) na aba do portal da transparência para essa aba da secretaria de administração e de repente o dado () eu não sabia mais onde estava. Dispensa de licitação tem que estar visivel assim, é algo que tem que estar lá 'Licitações' e logo embaixo 'dispensa de licitações', não pode simplesmente sumir ( ). Aí o que que eu costumo fazer, né? Eu até discuti com o pessoal, 'volta para o Google, pesquisa o termo, né? Prefeitura de Ribeirão Preto e coloca dispensa de licitação'. Então, assim, eu só consigo achar se eu for por fora () pelo site da prefeitura. Porque ele tão confuso e às vezes muda tanto que eu indo pelo Google vai mais rápido. Ai ( ) página () a página estava dentro da aba secretaria de administração, mas não sei por onde, não sei onde que estaria esse link, né? Isso é um dos exemplos assim, de macetes que a gente usa, né?" - Imprensa - C

"Eu tenho que ir lá, pegar um número da compra, voltar lá na aba de licitações, procurar o ano, licitações abertas ou licitações fechadas, ai é que eu pesquiso por lá. E também essa aba de licitações abertas, ela não é atualizada em tempo real, às vezes saí uma licitação, já aconteceu várias vezes no diário oficial, passa algumas horas, a gente vai lá ver se estar e a licitação não está lá, passa um dia e a licitação não está lá. E aí, a gente vai lá liga e cobra 'olha, eu queria ver aqui o edital' e ai você acha. Já teve casos também de colegas que falaram assim 'olha, uma vez eu liguei, os caras não colocaram, eu liguei de novo fingindo que era um empresário e eles me mandaram "'. - Imprensa - C 


\subsection{Justificativas para opacidade: Cultura e Capacidade Estatal}

Respondentes justificam que uma maior dificuldade de divulgação dos dados decorre de "questões culturais" e de capacidade estatal. Práticas organizacionais antigas e o desinteresse por transparência por parte da população não contribuem para a promoção da transparência (Roy, 2014) tanto para quem sofre pressão quanto para quem deveria exercer pressão.

A cultura do lado de quem tem o papel de divulgar parece estar associada aos costumes de servidores públicos em épocas que não havia transparência pública, devendo assimilar as mudanças da legislação de transparência com eventuais resistências em alguns servidores e consequentemente favorecendo a opacidade no paradoxo.

“...pessoas acostumarem com aquilo ali, acostumarem com aquele tipo de trabalho, de serviço, que funciona daquele jeito, que acha que tudo tem que ser escondido, né? ( ) eu acredito que é isso, então, aí as pessoas tende a ter dificuldade a adaptar quando vai ter uma mudança, né?" - Prefeitura - Caso 20

Apesar das resistências à mudança, o mesmo respondente se apresenta como favorável à divulgação de outros tipos de informações como licitações e contratos, e afirma que estão divulgados.

\footnotetext{
"P: O senhor sabe se tem algum problema pra divulgar informação sobre licitação e contrato no portal da transparência?

$X$ : Não vejo problema nenhum. O que que as pessoas tentam esconder essa informação, né? Se escondem é porque tem angu no caroço, tem caroço nesse angu. Os nossos contratos estão todos em aberto. " - Prefeitura - Caso 17
}

Já em relação a quem exerce o controle social, surge a falta de interesse por cobrar a transparência. Esta falta de interesse em procurar informações públicas pode estar relacionada ao fato de que possíveis cobranças de divulgação não tragam resultados positivos.

"Muito por questão cultural. As pessoas não têm esse costume, não crescem com esse costume, né? Não tem algo na escola que explique isso 'olha, você pode fiscalizar, você tem esse direito', né? É uma questão bem cultural...Tem gente que fala 'o que adianta eu fiscalizar? O que adianta eu acompanhar? Não vai resolver nada'. Então, tem uma série de fatores aí.” - Imprensa - Caso 1 


\begin{abstract}
"uma outra parte, assim, da população juventude que eles não estão nem aí, eles não querem nem saber esse tipo de informação [dados do portal da transparência], né? Eles querem outro tipo de informação. Então, é um pouco por conta disso mesmo, a falta de interesse, né?... eu acho que a população em geral, eles não querem consumir esse tipo de informação [dados do portal da transparência], eles preferem saber de fofoca ( ) outras coisas, mas essas informações, eu acredito que a maioria das pessoas nem estão interessadas em saber." - Prefeitura - Caso 28
\end{abstract}

Em relação à capacidade estatal, um servidor com função exclusiva voltada para a transparência com ferramentas adequadas poderia melhorar a transparência do município. Servidores ao terem a pressão por divulgação, justificam a falta de equipes dedicadas à transparência por restrições orçamentárias. A opacidade acaba sendo justificada pela menor capacidade estatal presente.

“E vou falar pra você, até hoje nós temos essa dificuldade. Por que? Nosso
município trabalha com poucos servidores e muitos processos. Então, nós não
conseguimos colocar toda essa parte de contratos no portal da transparênciá."
- Prefeitura - Caso 9
"eles não veem a importância ( ), por exemplo, 'eu preciso contratar lá na
saúde, lá na educação', é mais importante do que o portal da transparência
porque não vai atender o público, porque não vai estar ali direto. Eles têm essa,
esse pensamento que você precisa tentar mostrar 'olha, não é bem assim'. -
Prefeitura - Caso 27

Já a quem se beneficiaria pelo controle social com maior transparência, contradiz as falas dos agentes públicos citadas acima. Para esses, as questões orçamentárias não justificam a ausência de tal servidor com dedicação exclusiva pois os gastos com transparência não causam impacto negativo nas finanças públicas.

\footnotetext{
"E quando eles são cobrados, eles alegam que não tem estrutura, que não tem recurso para criar uma equipe, constituir uma equipe para fazer esse tipo de trabalho de divulgação, que na verdade é uma falácia. Porque isso não custa caro, né? A divulgação. " Organização Social - A
}

O efeito de cultura, capacidade estatal e pressão social afeta como agentes públicos pensam a respeito em contexto com e sem pandemia. As tensões e pressões exercidas pelos dois lados do paradoxo opacidade (sofre pressão para divulgar) vs. transparência (exerce pressão para que dados públicos sejam divulgados) fícam evidentes nas falas de alguns dos contadores entrevistados. Nas falas, os contadores expõem as pressões externas ao órgão que cobram a divulgação de informações e a resistência interna por parte de alguns agentes públicos em relação à publicização de dados. 
“a transparência está aí, a gente está sendo exigido cada vez mais. Eu acho que
tem muita coisa que eles estão colocando uma sobrecarga bem grande em cima
dos municipios, mas não vai mudar muita coisa, pra nós, não sei se ( ) coisa,
porque a gente já tem que fazer, é prestação de contas ( ), entendeu? Então,
assim, ( ) a gente tem que ir se adaptando.” - Prefeitura - Caso 28
“eu sinto resistência por parte de funcionários mais antigos, eu sinto resistência
por parte dos políticos e essa falta de interessa da população talvez ( )
qualidade da informação, eu acho que uma das coisa.” - Prefeitura - Caso 27
“saiu a covid e menos de um mês eles já mandaram uma cobrança, já saiu
publicado os municípios que não estavam atendendo. Acho que a nossa região
estavam todos porque era uma lista enorme, e entre eles estava eu. Então, eles
cobraram, não deu nem tempo de o ( ) desenvolverem.” - Prefeitura - Caso 27

Em algumas das falas dos respondentes que exercem pressão, eles expõem como o outro lado do paradoxo pode forçar a opacidade das informações públicas (Michener, Contreras, \& Niskier, 2018).

\begin{abstract}
"Ela tenta por vez ou outra omitir, né? A informação, ou deixar ela confusa ou deixar ela difícil de ser acessada nos portais de transparência, apesar de obrigação, ainda é muito dificil, né? ( ) e maneira correta, não é prioridade para a maioria das administrações públicas que a gente pelo menos ( ) que a gente monitorou e tem conhecimento, né?" - Organização Social - B

"No governo de SP também há muito problemas de transparência... E no governo municipal idem...Transparência vai muito além disso, é você ter dados bem estruturados, bem amplos e integros para que você não fique refém de uma narrativa que o governante queira criar numa coletiva de imprensa... Então, de um modo geral eu vi que a transparência teve retrocessos com a pandemia do coronavirus, infelizmente." - Imprensa - C
\end{abstract}

Todos os entrevistados demonstram as pressões sofridas ou exercidas relacionadas à transparência deixando claro suas posições em cada extremo do paradoxo. No extremo da opacidade é possível dizer que estão os entrevistados que sofrem pressão para divulgar informações. Enquanto que no extremo da transparência estão os respondentes que exercem pressão para que haja publicização de dados. Antes da pandemia, já existiam tensões, enquanto cultura e capacidade estatal (estrutura, recursos) puxava o paradoxo para o lado da opacidade, a regulação e demandas sociais puxavam para a abertura e transparência. Agentes públicos eram pressionados a ampliar a divulgação de informações, como contadores e responsáveis pelo setor de compras. Tais agentes públicos demonstram em certos momentos resistência em relação à divulgação de informações públicas principalmente aquelas que dizem respeito à remuneração. No 
entanto, estes mesmos agentes públicos são favoráveis à transparência de outros tipos de dados públicos. Este equilíbrio que existia antes da pandemia foi alterado.

\subsection{Como a pandemia afeta o equilíbrio então vigente}

A Pandemia ao mesmo tempo que simplifica processos de contratação nos estados de calamidade e emergência, forçou os governos a disponibilizarem informações extras (gastos detalhados com Covid-19, boletins da Covid-19, placar de vacinados etc.). O regime de exceção na contratação pode ter feito com que alguns agentes públicos interpretassem que as exigências de divulgação estavam reduzidas ou se valessem da situação para reduzir a divulgação. Assim, de certo modo a pandemia gerou uma contradição pois ampliou a transparência com a disponibilização de informações extras sobre a Covid-19, mas abriu uma brecha para aumento de contratações simplificadas que não são completamente transparentes, ou seja, as dispensas de licitação, cujas informações são publicadas após o fechamento do contrato.

As novas exigências para publicizar dados sobre o combate à pandemia provocou uma reação rápida das prefeituras. No entanto, a tentativa de atender a essas novas exigências de forma rápida fez com as informações fossem mal divulgadas pois pode ter ocorrido uma desorganização nos órgãos públicos em razão de não estarem plenamente preparados para lidar os problemas trazidos pela pandemia.

\footnotetext{
"Fazia uma lista do que tinha sido ( ), compras de seringas, compras de testes, vai, compra de testes rápidos, né? Tantos testes, pagou tanto na unidade, valor total tanto. Tiraram uma foto de um papel de uma folha sulfite escrito isso ai e colocaram lá. Isso não serve para praticamente nada, né? ( ) eles colocaram o CNPJ do fornecedor, não colocaram nem o nome, eles colocaram o CNPJ do fornecedor. Deu um trabalho gigantesco isso no começo, né? Para você tentar entender o que estava acontecendo, até você chegar nos finalmentes demorou dias. "- Organização Social - B
}

Por um lado, algumas secretarias de saúde passaram a emitir boletins da Covid19 com a quantidade de casos, leitos de UTI, casos tratados, mortes, agendamento de vacinação e números sobre vacinados. Por outro lado, as contratações se tornaram menos transparentes reduzindo capacidade de controle social.

$\mathrm{Na}$ fala abaixo, o entrevistado passa a impressão de superficialidade da transparência e que a simples divulgação nos sites é sinônimo de que a transparência está numa situação aceitável. 
"nas prefeituras aqui da região foi dar ênfase, uma visibilidade que eles nunca deram para a transparência, para os dados referentes à covid. Se você for acessar o site da prefeitura, por exemplo, a primeira informação que você vai ver no site da prefeitura em letras enormes é o agendamento da vacina. Você vai lá e clica nas opções, a primeira informação é agendamento, a segunda é normas estaduais de covid, a terceira é boletim da covid. E se vocêfor no portal da transparência a primeira informação que você vê é sobre covid ... Eles criaram uma página especifica para as receitas, contratos, licitações ( ) recursos humanos da covid e dentro da página de gastos em geral da prefeitura, eles também criaram uma opção para você ver os gastos com covid. " - Imprensa $-\mathrm{C}$

Um representante de câmara municipal, que também atua como alguém que exerce pressão por transparência expõe sua visão sobre como a dispensa de licitação é um processo de contratação pouco transparente.

\begin{abstract}
"Eu costumo entrar para acompanhar, mas geralmente a informação não está a tempo. Quando a gente vê, já foi contratada a empresa. Depende a situação, não é? Nos casos em que a licitação é obrigatória devido aos valores ( ) a gente consegue acompanhar. Nos casos em que, às vezes, a dispensa de licitação () valor do serviço contratado, quando a gente fica sabendo, o contrato já foi fechado... Aqui na câmara, por exemplo, como os serviços contratados tem o valor muito pouco, aqui a gente utiliza pela dispensa de licitação... Só que aí não tem aquela publicidade que teria no caso de ter licitação ( ) obrigatoriedade de publicar em vários locais, toda aquela burocracia." Câmara Municipal - Caso 22
\end{abstract}

Para um membro de organização social, as dispensas de licitações destinadas ao combate da pandemia reduziram a possibilidade de controlar tais gastos e permitiram um possível entendimento equivocado de como destinar recursos públicos em um regime de exceção.

\footnotetext{
"Essa lei [da pandemia, Lei $N^{o}$ 13.979/20], ela dispensou nas compras emergenciais de ter maiores controles. E são bilhões que estão sendo gastos. Então, ai permite para o mau gestor a opacidade( ) porque ele justifica na lei que ele está ( ) covid tem que ser rápido, tem que ser daquele jeito e não tem muita informação a prestar. " - Organização Social - A
}

Segundo um jornalista entrevistado, a interpretação do Supremo Tribunal Federal sobre a divulgação dos gastos contra a Covid-19 pode ter dado poder aos gestores públicos para que eles decidissem o nível de transparência sobre o tema.

“no começo da pandemia, eles não estavam fazendo mais licitação, né? Por causa desse vírus aí. E eu estava vendo um vídeo ontem até interessante. $O$ Supremo, ele deu poderes de autoridades ( ) para prefeitos e governadores e 
isso, se a pessoa quer se auto beneficiar com isso não tem como descobrir, né? Porque não sabe onde está investindo o dinheiro." - Imprensa - Caso 7

O mesmo representante de câmara municipal do Caso 22 coloca como a dispensa de licitação pode dificultar o controle social deste processo de contratação por meio do acesso ao portal da transparência. Ao mesmo tempo, ele também justifica a escolha de contratar por meio da dispensa de licitação.

“... boa por um lado [dispensa de licitação], porque é um processo bastante rápido para a gente também os custos de fazer uma licitação de publicação em jornais de grande circulação, no diário oficial do Estado ( ) essas publicações que são obrigatórias. Independente da ( ) a gente tem que fazer. Mas é um custo que também é reduzido. Porém, por outro lado, como é pesquisa de preço, acho que fica meio dificil ter um controle mais efetivo." - Câmara Municipal - Caso 22

Um jornalista compartilha a mesma opinião de que a dispensa de licitação também é um processo de contratação pouco transparente.

\footnotetext{
"Até porque a dispensa mesmo, ela só fica divulgada, só é divulgada quando já tem um contrato assinado, quando o serviço já está contratado ou o material já foi contratado, né? A divulgação só saí quando já está fechado o negócio, vamos dizer assim." - Imprensa - C
}

O equilíbrio no paradoxo pode ser alterado por mudança da regulação ou de seu entendimento (que exige das organizações soluções para novas tensões que possam surgir) ou no curto prazo por choques externos abruptos, como a corrente pandemia. Exemplo de nova regulação afetando o equilíbrio no paradoxo ocorreu com uma empresa de telecomunicações da Europa a qual teve que se reestruturar para atender a uma nova regulamentação. A reestruturação da empresa precisou se adequar a nova regulação que tinha o propósito de garantir a competitividade do mercado, mas também se opunha ao comportamento competitivo deste mesmo mercado (Jarzabkowski, Lê, \& Van de Ven, 2013).

$\mathrm{Na}$ presente análise a pandemia é vista como o fator externo que alterou o equilíbrio até então existente na transparência de organizações públicas. Até então, a transparência de contratações restringia-se ao que era cobrado pela legislação e apresentada de modo a atender aos órgãos fiscalizadores. Mas com o advento da pandemia e o regime de exceção, pode ter ocorrido uma interpretação de como a regulação de transparência (que não foi alterada) deveria ser aplicada, ou em que medida 
Tribunais de Contas continuariam exigindo as mesmas regras de publicização. $O$ entendimento não foi claro a todos, alguns entenderão que deveria ser publicado desde o início:

"no primeiro momento eu entendi, 'ah tem que publicar', tá, todas as coisas tem que serem publicadas, vai estar lá, eu vou constando que é covid, vai saber, mas não, né? Tinha que ser separado, tinha que ter um icone só para a covid." Prefeitura - Caso 27

Mas outros desenvolveram seu entendimento paulatinamente:

\begin{abstract}
"Então, algumas opções que nós temos hoje, elas foram implementadas durante a pandemia, né? Então, não foi de imediato ( ) começaram a acontecer com o passar do tempo, né? Foi melhorando e foi disponibilizando." - Prefeitura Caso 19

"O portal, conforme as exigências ao longo do tempo, foi evoluindo, o sistema foi desenvolvendo e hoje tem uma infinidade de informações. $O$ covid foi a mesma coisa, começou, primeiro não tinha exigência nenhuma de separar no portal. Depois exigiu que separasse dentro do próprio portal, você clicando no item, joga você lá para as despesas do covid. Ai depois, aí foi exigindo outras coisas, licitação, decretos, funcionários que contratou, ( ) excepcionais que pagam por conta da covid para as pessoas" - Prefeitura - Caso 8
\end{abstract}

Outros relatam sinais dados pelo Governo Federal em relação à transparência de dados de mortes e casos da Covid-19. De certa forma esse sinal poderia ser usado como justificativa para transparência de outras informações nos governos locais, como dados de contratação.

\begin{abstract}
"Na pandemia, o Ministério da Saúde teve muitos retrocessos [em relação à transparência]... o portal do governo federal que fazia o monitoramento de casos de infectados e mortes da pandemia foi retirado do ar e depois reapresentado em formato muito inferior ao que existia antes... Depois quando trocou o ministro esse portal saiu do ar e funcionalidades foram retiradas e só depois de muita pressão da sociedade, elas foram sendo reinseridas." Imprensa - C
\end{abstract}

As prefeituras adequaram ou não o nível de transparência com a mudança de contexto. Quando prefeitos se viram obrigados a contratar com rapidez, ou que poderiam se beneficiar das contratações via dispensas, passaram a ignorar/desconsiderar a necessidade da transparência e aguardaram vir uma demanda do TCE e do Ministério Público.

Quando fazem isso no início da pandemia, em que os Tribunais de Contas não estavam ativos, não existia pressão de tais órgãos de controle, nem da câmara ou sociedade. Então, os casos em que já não havia divulgação, continuaram sem 
publicização. Os casos que tinham alguma transparência em outros itens que não de Covid-19, ocorreu redução da transparência no caso de itens para Covid-19.

Nos casos da Tabela 6 em que houve aumento, são relativos a outros objetos, ou seja, contratações não relacionadas a insumos da Covid-19, que tiveram uma divulgação bem menor. Ou seja, a transparência foi menor durante a pandemia. Nestes casos, os agentes públicos como prefeitos e contadores migraram para opacidade porque não houve pressão por TCE, câmaras ou ONGs a ponto de prefeitos darem atenção à questão. 


\section{CONCLUSÃO E IMPLICAÇÕES}

A discussão de paradoxo na abertura de governos neste estudo explorou as dispensas de licitações antes e durante a pandemia da Covid-19 e a publicização de serviços terceirizados em governos locais. As dispensas de licitações e a terceirização de serviços foram explorados pois levantam questões que fazem surgir tensões e pressões no paradoxo opacidade $v s$. transparência. A análise das dispensas de licitação comparou a publicização dos documentos destes processos de contratação antes e durante a pandemia. Na comparação do total de dispensas de licitações de todos os casos foi observada que a média de divulgação completa (dispensas de licitações com contratos disponibilizados em formato pdf) diminuiu entre os anos de 2019 e 2020. No entanto, a comparação individual de cada caso observou aumentos em contratações que não tinham objetivo de combater a pandemia e diminuições na divulgação completa das dispensas de licitações com a chegada da pandemia.

A análise da divulgação das dispensas de licitações foi complementada com entrevistas que também abordaram questões sobre a publicização de serviços terceirizados. Os relatos coletados nas entrevistas trazem as tensões que envolvem a abertura de informações de governos (Kornberger, Meyer, Brandtner, \& Höllerer, 2017). Os agentes públicos que representam o papel da divulgação da informação (que recebem pressões por divulgar) expuseram a evolução da transparência e como tentam resolver as demandas internas e externas relacionadas com o tema (Graham, Gooden, \& Martin, 2016). Os atores que exercem o papel de controle e que usariam a informação (exercendo pressão pela divulgação) também mencionam como a abertura dos governos evoluiu, mas criticaram a existência de barreiras que dificultam o avanço da publicização de informações públicas (Luciano, Wiedenhöft, \& Santos, 2018). Os interessados em informações públicas compreendem as dificuldades e anseios dos outros atores, os que controlam refletem sobre o papel dos que divulgam, e vice-versa. Contadores e demais agentes públicos podem entender os obstáculos encontrados pela imprensa e demais interessados na tentativa de obter dados públicos. Da mesma forma, estes mesmos interessados podem compreender e cobrar a posição dos agentes públicos em relação à transparência.

O equilíbrio até então existente neste paradoxo foi alterado com o advento da pandemia que também provocou um regime de exceção nas contratações públicas. $\mathrm{O}$ 
evento crítico e repentino como a pandemia aflorou as tensões e pressões (Smith \& Lewis, 2011) do paradoxo opacidade vs. transparência. O afloramento das tensões e pressões no paradoxo em questão teve reflexo direto nos documentos coletados. A obrigação de combater a pandemia de forma rápida fez com os governos optassem por aumentar as contratações por meio das dispensas de licitações. Assim, alguns casos estudados não priorizaram a divulgação completa deste tipo de contratação simplificada.

Tanto o aumento (apenas para contratações que não tinham o objetivo de combater a pandemia) quanto a diminuição da divulgação completa podem ser evidências da alteração do equilíbrio do paradoxo provocado pela pandemia. Nos casos com aumento da divulgação completa, os agentes públicos responsáveis pela transparência podem ter sentido uma pressão maior por aqueles que cobram publicização. Assim, procuraram atender às novas demandas cobradas pelos demais interessados em informações públicas. Nos casos com diminuição de divulgação, pode ter ocorrido uma situação inversa à citada acima ou ainda os agentes públicos podem ter entendido que o regime de exceção propiciou um afrouxamento na transparência.

Agentes públicos e demais interessados em informações públicas reagiram defendendo seus interesses e de certa forma justificando uma posição no paradoxo (Smith \& Lewis, 2011) e, às vezes, criticando outras posições divergentes. Com a mudança no equilíbrio das tensões no paradoxo, as partes precisam gerenciar de alguma forma as tensões e pressões (Smith \& Lewis, 2011). No caso em questão, as partes responsáveis por divulgar e as por cobrar parece que não levaram as tensões ao extremo, talvez pela própria condição social da pandemia. Por exemplo, o Tribunal de Contas do Estado de São Paulo atuou em relação à baixa transparência das divulgações e colocou a cobrança de multa pelo não cumprimento como uma possibilidade e não como uma certeza (Tribunal de Contas do Estado de São Paulo, 2021).

Em termos de implicações da pesquisa, sugere-se que órgãos de controle coloquem a atenção em como a flexibilização de certas regulações afetam o entendimento de outras. Ainda, como que o cumprimento da regulação de transparência é afetado por diversas tensões e pode ter retrocessos dependendo de choques específicos. Por exemplo, como que situações sociais críticas podem ser usadas para justificar relaxamento de certas regras. Muitos municípios sofreram consequências mais severas em relação à saúde pública durante a pandemia. Os prefeitos destes municípios decretaram situação de calamidade para que pudessem combater a pandemia de forma mais ágil. Dentro dessa 
agilidade para enfrentar a Covid-19, o decreto de calamidade permitiu que os prefeitos realizassem contratações sem limite de valor por meio das dispensas de licitações. Apesar da dispensa de licitação oferecer agilidade, reduz o controle social por ser um processo de contratação pouco transparente. Interessante que a pandemia ampliou a divulgação de dados sobre gastos com Covid-19, boletins da Covid-19, vacinação etc. Porém, justificou o aumento de contratações pouco transparentes, no caso, as dispensas de licitações.

Uma das limitações da pesquisa foi não abranger todos os municípios do Estado de São Paulo. A abrangência de todos os municípios do Estado poderia captar a visão de agentes públicos que utilizam outros softwares de gestão pública diferentes. Além disso, não foi possível entrevistar outros interessados na abertura de governos como técnicos de órgãos de controle, conselheiros municipais de saúde e os desenvolvedores do software utilizados pelos entes públicos estudados. Apesar das limitações, esse estudo contribui para a sociedade ao mostrar que a vigilância da transparência governamental tem que ser algo constante, mesmo entes com um certo nível de estabilidade e constância nas divulgações podem facilmente mudar o ponto de equilíbrio entre opacidade e transparência, tendendo para a opacidade, quando encontram espaço para isso.

Pesquisas futuras podem realizar estudos de casos para tentar explicar os motivos de simplificações de contratações levarem ao relaxamento da transparência. Outros estudos podem ainda pesquisar sobre a atuação dos órgãos de controle na transparência em momentos críticos como a pandemia. 


\section{REFERÊNCIAS}

Abdala, P., \& Torres, C. S. (2016). A Transparência como Espetáculo: uma análise dos portais de transparência de estados brasileiros. Administração Pública e Gestão Social, pp. 1(3), 147-158.

Adu, K. (2018). The paradox of the right to information law in Africa. Government Information Quarterly, pp. 35(4), 669-674.

Agência Senado. (2019). Situação de emergência e estado de calamidade pública. Fonte: Senado Federal: Recuperado de https://www12.senado.leg.br/noticias/especiais/especial-cidadania/defesacivil/situacao-de-emergencia-e-estado-de-calamidade-publica

Agência Senado. (2020). Medida provisória suspende prazos de respostas via Lei de Acesso à Informação. Fonte: Senado Federal: https://www12.senado.leg.br/noticias/materias/2020/03/24/medida-provisoriasuspende-prazos-de-respostas-via-lei-de-acesso-a-informacao

Alampay, E. (14 de 08 de 2020). Open Government Data Governance in the Time of the Pandemic. Fonte: SSRN: Social Science Research Network: Recuperado de: https://ssrn.com/abstract $=3581408$

Altayar, M. S. (2018). Motivations for open data adoption: An institutional theory perspective. Government Information Quarterly, pp. 35(4), 633-643.

Alves, T. (2019). Panorama da contratação temporária e terceirização nos Municípios. Fonte: Confederação Nacional dos Municípios: Recuperado de https://www.cnm.org.br/cms/biblioteca/Panorama\%20da\%20terceiriza\%C3\%A7 $\% \mathrm{C} 3 \% \mathrm{~A} 3 \mathrm{o} \% 20 \mathrm{e} \% 20$ contrata $\% \mathrm{C} 3 \% \mathrm{~A} 7 \% \mathrm{C} 3 \% \mathrm{~A} 3 \mathrm{o} \% 20$ tempor $\% \mathrm{C} 3 \% \mathrm{~A} 1$ ria.pdf

Antunes, M. C. (2018). A efetividade informacional dos portais de transparência governamentais na perspectiva do cidadão. Perspectivas em Gestão \& Conhecimento, pp. 8(2), 162-178.

Antunes, M. C. (2018). A efetividade informacional dos portais de transparência governamentais na perspectiva do cidadão. Perspectivas em Gestão \& Conhecimento, pp. 8(2), 162-178.

Apufpr. (2018). Temer libera por decreto a terceirização nos serviços públicos federais. Fonte: Associação dos Professores da Universidade Federal Do Paraná: https://apufpr.org.br/2018/09/27/temer-libera-por-decreto-a-terceirizacao-nosservicos-publicos-federais/

Araújo, A., \& Doroteu, L. R. (2013). O exercício da cidadania na fiscalização popular dos crimes relacionados à Lei 8666/93. Fonte: Âmbito Jurídico: https://ambitojuridico.com.br/cadernos/direito-administrativo/o-exercicio-dacidadania-na-fiscalizacao-popular-dos-crimes-relacionados-a-lei-8666-93/

Araújo, F. C., \& Loureiro, M. R. (2005). Por uma metodologia pluridimensional de avaliação da LRF. Revista de Administração Pública, pp. 39(6), 1231-52. 
AssUFRGS. (2018). Decreto de terceirização no serviço público abre a possibilidade de terceirização das atividades do PCCTAE. Fonte: Sindicato dos Servidores Técnico-Administrativos da UFRGS, da UFCSPA e do IFRS: Recuperado de https://www.assufrgs.org.br/2018/10/01/decreto-de-terceirizacao-no-servicopublico-abre-a-possibilidade-de-terceirizacao-das-atividades-do-pcctae/

Bannister, F., \& Connolly, R. (2011). The trouble with transparency: A critical review of openness in e-government. Policy \& Internet, pp. 3(1), 158-87.

Bardin, L. (2006). Análise de conteúdo (L. de A. Rego \& A. Pinheiro, Trads.). Lisboa: Edições 70 (Obra original publicada em 1977).

Batista, R. (2020). Fonte: Senado Federal: Recuperado de https://www12.senado.leg.br/noticias/materias/2020/03/20/em-sessao-historicasenado-aprova-calamidade-publica-contra-covid-19

Bellintani, N. (2019). Fonte: Guia Terceirização 2019. Veja como e as Vantagens de Terceirizar: Recuperado de https://www.pontotel.com.br/terceirizacao-e-pelareforma-trabalhista/

Bernardes, M. B., Santos, P. M., \& Rover, A. J. (2015). Ranking das prefeituras da região Sul do Brasil: uma avaliação a partir de critérios estabelecidos na Lei de Acesso à Informação. Revista de Administração Pública, pp. 49(3), 761-792.

Berti, M., \& Simpson, A. (2019). The dark side of organizational paradoxes: The dynamics of disempowerment. Academy of Management Review, p. in press.

Bertoncini, M., \& Simão, I. C. (2019). A terceirização no âmbito da administração pública federal: o Decreto 9.507/2018 é constitucional? Revista Brasileira de Direito, pp. 15(2), 173-196.

Biavaschi, ,. M., \& Droppa, A. (2011). A história da súmula 331 do tribunal superior do trabalho: a alteração na forma de compreender a terceirização. Revista Mediações, pp. 16, 124-141.

Brei, Z. (1996). Corrupção: dificuldades para definição e para um consenso. Revista de Administração Pública, pp. 30 (1), 64-77.

Brito, S. M. (2018). "Estados imaginados" e novas virtudes: notas sobre a construção das políticas de transparência e combate à corrupção. Horizontes Antropológicos, pp. 24(50), 25-52.

Campos, M. (2019). A pedido do Ministério Público do Trabalho, a Justiça reconheceu a prática de fraude na terceirização de médicos do Hospital Universitário de Canoas. Fonte: O Sul: Recuperado de https://www.osul.com.br/uma-liminar-doministerio-publico-do-trabalho-reconhece-a-pratica-de-fraude-na-terceirizacaode-medicos-do-hospital-universitario-de-canoas/

Carneiro, F. M. (2016). A terceirizaão na administração pública: vantagens, desvantagens e ameaças ao regime jurídico das relações de trabalho. Revista de Direito Administrativo e Gestão Pública, pp. 2(2), 61-80. 
Castro, H. A., \& Dias, L. N. (2019). Mídias Sociais Como Estratégia de Atendimento à Lei de Acesso à Informação. Revista Paraense de Contabilidade, pp. 4(3), 6-23 .

Chatwin, M., Arku, G., \& Cleave, E. (2019). Defining subnational open government: Does local context influence policy and practice? . Policy Sciences, pp. 52, 451479.

Chen, M. J. (2002). Transcending paradox: The Chinese "middle way" perspective. Asia Pacific Journal of Management, pp. 19(2), 179-199.

Chiavenato, I. (2008). Administração pública (2a ed). Rio de Janeiro: Elsevier.

Clark, C. M., Tan, M. L., Murfett, U. M., Rogers, P. S., \& Ang, S. (2019). The call center agent's performance paradox: A mixed-methods study of discourse strategies and paradox resolution. Academy of Management Discoveries, pp. 5(2), 152-170.

Congresso em Foco. (2020). Painel COVID-19. Fonte: https://congressoemfoco.uol.com.br/covid19/index.html

Costa, F. (2020). Sem apresentar dados, Amazonas defende compra de respiradores 'inadequados'. Fonte: UOL: https://noticias.uol.com.br/saude/ultimasnoticias/redacao/2020/04/23/sem-apresentar-dados-amazonas-defende-comprade-respiradores-inadequados.htm

Costa, J. L., \& Gularte, J. (2019). Grupo de empresas que atende órgãos públicos é investigado por suspeita de lesar trabalhadores e contratantes. Fonte: Gaúchazh: Recuperado de https:/gauchazh.clicrbs.com.br/grupo-deinvestigacao/noticia/2019/11/grupo-de-empresas-que-atende-orgaos-publicos-einvestigado-por-suspeita-de-lesar-trabalhadores-e-contratantesck2p5ohd6006501o0s93q4z8y.html

Costa, L. M. (2020). A corrupção nos tempos da covid-19. Fonte: Estadão: Recuperado de https://politica.estadao.com.br/blogs/gestao-politica-e-sociedade/a-corrupcaonos-tempos-da-covid-19/

Cronin, A. M. (2020). The secrecy-transparency dynamic: A sociological reframing of secrecy and transparency for public relations research. Public Relations Inquiry.

Cruz, M. C., Silva, T. A., \& Spinelli, M. V. (2016). O papel das controladorias locais no cumprimento da Lei de Acesso à Informação pelos municípios brasileiros. Cadernos EBAPE.BR, pp. 14(3), 721-743.

Cuganesan, S. (2017). Identity Paradoxes: How Senior Managers and Employees Negotiate Similarity and Distinctiveness Tensions over Time. Organization Studies, pp. 38(3-4), 489-511.

Cunha, M. P., Simpson, A. V., Clegg, S. R., \& Rego, A. (2018). Speak! Paradoxical Effects of a Managerial Culture of 'Speaking Up'. British Journal of Management, pp. 30, 829-846.

Dantas, C. (2020). Coronavírus, Covid-19, Sars-Cov-2 e mais: veja a explicação para 16 termos usados na pandemia. Fonte: G1: Recuperado de https://g1.globo.com/bemestar/coronavirus/noticia/2020/03/24/coronavirus- 
covid-19-sars-cov-2-e-mais-veja-a-explicacao-para-16-termos-usados-napandemia.ghtml

Decreto Legislativo $\mathrm{n}^{\mathrm{o}}$ 6, de 2020. Reconhece, para os fins do art. 65 da Lei Complementar $\mathrm{n}^{\circ} 101$, de 4 de maio de 2000, a ocorrência do estado de calamidade pública, nos termos da solicitação do Presidente da República encaminhada por meio da Mensagem $\mathrm{n}^{\mathrm{o}}$. (s.d.). Fonte: Recuperado de http://www.planalto.gov.br/ccivil_03/portaria/DLG6-2020.htm

Decreto n ${ }^{0} 64.881$ de 22 de março de 2020, Decreta quarentena no Estado de São Paulo, no contexto da pandemia do COVID-19 (Novo Coronavírus), e dá providências complementaresd. (2020). Fonte: Governo do Estado de São Paulo: https://www.saopaulo.sp.gov.br/wp-content/uploads/2020/03/decretoquarentena.pdf

Decreto $\mathrm{n}^{\mathrm{o}} 64.920$ de 06 de abril de 2020, estende o prazo da quarentena de que trata $\mathrm{o}$ Decreto $n^{\circ}$ 64.881, de 22 de março de 2020, e dá providências correlatas. (2020). Fonte: Governo do Estado de São Paulo: Recuperado de http://diariooficial.imprensaoficial.com.br/nav_v5/index.asp?c=4\&e=20200407 $\& p=1$

Decreto $n^{0} 64.946$ de 17 de abril de 2020, prorroga a quarentena em todo o Estado de São Paulo até 10 de maio de 2020. (2020). Fonte: Governo do Estado de São Paulo: Recuperado de http://dobuscadireta.imprensaoficial.com.br/default.aspx?DataPublicacao=20200 418\&Caderno $=$ DOE-I\&NumeroPagina $=1$

Decreto $\mathrm{n}^{\circ}$ 9.507, de 21 de setembro de 2018, Dispõe sobre a execução indireta, mediante contratação, de serviços da administração pública federal direta, autárquica e fundacional e das empresas públicas e das sociedades de economia mista controladas pela. (s.d.). Fonte: Recuperado de http://www.in.gov.br/materia//asset_publisher/Kujrw0TZC2Mb/content/id/42013574/do1-2018-09-24decreto-n-9-507-de-21-de-setembro-de-2018-42013422

Del Luca, F. V., \& Bender Filho, R. (2016). Processo licitatório da prefeitura de Passo Fundo: análise das licitações sem êxito. Revista Gestão Pública Práticas e Desafios, p. 9(1).

Di Pietro, M. S. (2009). Parcerias na administração pública (7a ed.). São Paulo: Atlas.

Dias, L. N., Aquino, A. C., Silva, P. B., \& Albuquerque, F. S. (2020). Terceirização de portais de transparência fiscal em prefeituras municipais. Revista de Contabilidade e Organizações, pp. 14, 1-15.

Drummond, H. (2008). The Icarus paradox: An analysis of a totally destructive system. Journal of Information Technology, pp. 23(3), 176-184.

EPTV. (2017). 'Não tem como adivinhar', diz autarquia sobre contrato de coleta do lixo suspeito de fraude em Barretos. Fonte: G1 Ribeirão Preto e Franca: Recuperado de

https:/g1.globo.com/sp/ribeirao-preto-franca/noticia/nao-tem-como- 
adivinhar-diz-autarquia-sobre-contrato-de-coleta-do-lixo-suspeito-de-fraude-embarretos.ghtml

EPTV. (2020). Empresa alvo de operação que apurou fraudes em contratos de coleta de lixo paga $R \$$ 10,5 milhões após acordo. Fonte: G1: Recuperado de https://g1.globo.com/mg/sul-de-minas/noticia/2020/02/17/empresa-alvo-deoperacao-que-apurou-fraudes-em-contratos-de-coleta-de-lixo-paga-r-105milhoes-apos-acordo.ghtml

Estado de São Paulo. (2020). https://www.saopaulo.sp.gov.br/ultimas-noticias/governode-sao-paulo-anuncia-medidas-de-combate-ao-coronavirus/. Fonte: Estado de São Paulo: https://www.saopaulo.sp.gov.br/ultimas-noticias/governo-de-saopaulo-anuncia-medidas-de-combate-ao-coronavirus/

Estado de São Paulo. (2020). Retomada consciente. Fonte: Recuperado de https://www.saopaulo.sp.gov.br/planosp/

Estado de São Paulo. (s.d.). Governo de SP propõe antecipar feriado estadual para 25 de maio. Fonte: Estado de São Paulo: https://www.saopaulo.sp.gov.br/ultimasnoticias/governo-de-sao-paulo-anuncia-medidas-de-combate-ao-coronavirus/

Fan, B., \& Zhao, Y. (2017). The moderating effect of external pressure on the relationship between internal organizational factors and the quality of open government data. Government Information Quarterly, pp. 34(3), 396-405.

Farjoun, M. (2010). Beyond dualism: Stability and change as a duality. Academy of Management Review, pp. 35(2), 202-225.

Fenasps. (2018). Todos às ruas no dia 24 de outubro de 2018 em defesa das liberdades democráticas, por serviço público de qualidade, direitos e aposentadorias! Fonte: A Federação Nacional de Sindicatos de Trabalhadores em Saúde, Trabalho, Previdência e Assistência Social: Recuperado de http://www.fenasps.org.br/noticias-sp-9550/1798-todos-as-ruas-no-dia-24-deoutubro-de-2018-em-defesa-das-liberdades-democraticas-por-servico-publicode-qualidade-direitos-e-aposentadorias

Ferreira, C. D., Silva, E. K., Silva, G. C., \& Miranda, L. C. (2014). Accountability da Gestão Pública Municipal na Região Sudeste e a Adequação à Lei Complementar 131/2009. Congresso USP. São Paulo.

Folha de SP. (2020). Veja o que abre e o que fecha na fase vermelha durante feriado em SP. Fonte: Folha de SP: https://www1.folha.uol.com.br/cotidiano/2020/12/vejao-que-abre-e-o-que-fecha-na-fase-vermelha-durante-feriado-em-sp.shtml

Freitas, D. X. (2015). Prefeitura é processada por fraude na terceirização da saúde. Fonte: Jusbrasil: Recuperado de https://daniellixavierfreitas.jusbrasil.com.br/noticias/176462993/prefeitura-eprocessada-por-fraude-na-terceirizacao-da-saude

G1. (2020). Ebserh lança edital para contratação temporária de até 6 mil profissionais para combate à Covid-19. Fonte: G1: Recuperado de https://g1.globo.com/economia/concursos-e-emprego/noticia/2020/04/01/ebserh- 
lanca-edital-para-contratacao-temporaria-de-ate-6-mil-profissionais-paracombate-a-covid-19.ghtml

G1 PR. (2019). Polícia investiga se mais servidores do Hospital Universitário de Londrina estão envolvidos em esquema de corrupção. Fonte: G1: Recuperado de: https://g1.globo.com/pr/norte-noroeste/noticia/2019/03/12/policia-investiga-semais-servidores-do-hospital-universitario-podem-estar-envolvidos-em-esquemade-corrupcao.ghtml

G1 SP. (2020). Cidades do litoral norte de SP fazem barreiras sanitárias para chegada de turistas para feriadão. Fonte: G1: https://g1.globo.com/sp/vale-do-paraibaregiao/noticia/2020/09/04/cidades-do-litoral-norte-de-sp-fazem-barreirassanitarias-para-chegada-de-turistas-para-feriadao.ghtml

G1 SP. (2020). Região de Ribeirão Preto é rebaixada para a fase laranja do Plano SP e fecha academias, bares e restaurantes. Fonte: G1: https://g1.globo.com/sp/ribeirao-preto-franca/noticia/2020/09/04/regiao-deribeirao-preto-e-rebaixada-para-a-fase-laranja-do-plano-sp-e-fecha-academiasbares-e-restaurantes.ghtml

G1 SP. (2021). Entenda as fases do Plano São Paulo, que regulamenta o que pode funcionar na quarentena em SP; veja perguntas e respostas. Fonte: G1: https://g1.globo.com/sp/sao-paulo/noticia/2021/01/23/entenda-as-fases-doplano-sao-paulo-que-regulamenta-o-que-pode-funcionar-na-quarentena-em-spveja-perguntas-e-respostas.ghtml

G1, MA. (2021). Município e empresários são acionados por irregularidades em licitação no interior do Maranhão. Fonte: G1: https://g1.globo.com/ma/maranhao/noticia/2021/06/30/municipio-eempresarios-sao-acionados-por-irregularidades-em-licitacao-no-interior-domaranhao.ghtml

Gaim, M., Clegg, S., \& Cunha, M. (2019). Managing impressions rather than emissions: Volkswagen and the false mastery of paradox. Organization Studies.

Gallego, J. A., Prem, M., \& Vargas, J. (2020). Corruption in the times of pandemia. Fonte: SSRN: Social Science Research Network: Recuperado de: https://papers.ssrn.com/sol3/papers.cfm?abstract_id=3600572

Gascó-Hernández et al., 2. M.-H., Martin, E. G., Reggi, L., Pyo, S., \& Luna-Reyes, L. F. (2018). Promoting the use of open government data: Cases of training and engagement. Government Information Quarterly, pp. 35(2), 233-242.

Gonzalez-Zapata, F., \& Heeks, R. (2015). The multiple meanings of open government data: Understanding different stakeholders and their perspectives. Government Information Quarterly, pp. 32(4), 441-452.

Governo de São Paulo. (2020). Governo de SP vai contratar 1.185 profissionais de saúde em caráter emergencial. Fonte: Governo de São Paulo: Recuperado de https://www.saopaulo.sp.gov.br/noticias-coronavirus/contratar-profissionaissaude-carater-emergencial/ 
Governo de São Paulo. (2020). Transparência corovírus. Fonte: Governo de São Paulo: Recuperado de https://www.saopaulo.sp.gov.br/coronavirus/transparencia/

Graham, F. S., Gooden, S. T., \& Martin, K. J. (2016). Navigating the TransparencyPrivacy Paradox in Public Sector Data Sharing. American Review of Public Administration, pp. 46, 569-591.

Grigore, G., Molesworth, M., Miles, C., \& Glozer, S. (2021). Un-resolving Digital Technology Paradoxes Through the Rhetoric of Balance. Organization, pp. 28(1): 186-209.

Grimmelikhuijsen, S. G., \& Feeney, M. K. (2017). Developing and testing an integrative framework for open government adoption in local governments. Public Administration Review, pp. 77,(4) 579-590.

Grizotti, G. (2015). 20/07/2015 09h07 - Atualizado em 20/07/2015 09h51. Fonte: G1 Rio Grande do Sul: Recuperado de http://g1.globo.com/rs/rio-grande-dosul/noticia/2015/07/mp-apura-fraude-em-licitacoes-com-envolvimento-de-10empresas-no-rs.html

Groscurth, C. R. (2011). Paradoxes of privilege and participation: The case of the American Red Cross. Communication Quarterly, pp. 59(3), 296-314.

Guimarães, A., Zuba, F., Leitão, L., \& Martins, M. A. (2020). Aquisição de hospitais de campanha tem proposta plagiada e 'concorrente' fantasma no RJ. Fonte: G1: Recuperado de https:/g1.globo.com/rj/rio-dejaneiro/noticia/2020/04/17/aquisicao-de-hospitais-de-campanha-tem-propostaplagiada-e-concorrente-fantasma-no-rj.ghtml

Hatch, M. J., \& Erhlich, S. B. (1993). Spontaneous humour as an indicator of paradox and ambiguity in organizations. Organization Studies, pp. 14(4), 505-526.

Hautz, J., Seidl, D., \& Whittington, R. (2017). Open strategy: Dimensions, dilemmas, dynamics. Long Range Planning, pp. 50(3), 298-309.

Heald, D. (2003). Fiscal transparency: Concepts, measurement and UK practice. Public administration, pp. 81(4), 723-759.

Herriott, R. E., \& Firestone, W. A. (1983). Multisite qualitative policy research: optimizing description and generalizability. Educational Researcher, pp. 12(2): $14-19$.

Huq, J.-L., Reay, T., \& Chreim, S. (2017). Protecting the Paradox of Interprofessional Collaboration. Organization Studies, pp. 38(3-4): 513-538.

IGESDF. (2020). Transparência - salário pessoal contratado covid-19. Fonte: Instituto de Gestão Estratégica de Saúde: Recuperado de https://igesdf.org.br/transparencia/salarios/relacao-de-salarios-fevereiro-de2020-2/

Jacques, F. V., Quintana, A. C., \& Macagnan, C. B. (2013). Transparência em Municípios da Região Sul do Brasil. XXXVII Encontro do Anpad. Rio de Janeiro. 
Janssen, M., Charalabidis, Y., \& Zuiderwijk, A. (2012). Benefits, adoption barriers and myths of open data and open government. Information systems management, pp. 29(4), 258-268.

Jarzabkowski, P. A., \& Lê, J. K. (2017). We Have To Do This and That? You Must be Joking: Constructing and Responding to Paradox Through Humor. Organization Studies, pp. 38(3-4), 433-462.

Jarzabkowski, P., Lê, J. K., \& Van de Ven, A. H. (2013). Responding to competing strategic demands: How organizing, belonging, and performing paradoxes coevolve. Strategic Organization, pp. 11(3), 245-280.

Jay, J. (2013). Navigating paradox as a mechanism of change and innovation in hybrid organizations. . Academy of Management Journal, pp. 56(1), 137-159.

Jesus, A. G. (2020). Legalidade da dispensa de licitação nas contratações públicas para enfrentamento da pandemia do COVID-19. Fonte: Âmbito Jurídico: https://ambitojuridico.com.br/cadernos/direito-administrativo/legalidade-dadispensa-de-licitacao-nas-contratacoes-publicas-para-enfrentamento-dapandemia-do-covid-19/

Jezierska, K., \& Sörbom, A. (2020). Proximity and distance: Think tanks handling the independence paradox. Governance, pp. 1-17.

Jordão, E. (2014). A intervenção do TCU sobre editais de licitação não publicados Controlador ou administrador? Revista Brasileira de Direito Público, pp. 12 (47), 209-230.

Júnior, J. T. (2001). Aspectos Constitucionais da Lei de Responsabilidade Fiscal. Revista da EMERJ, pp. 4,(15).

Keuffer, N., \& Mabillard, V. (2019). Administrative openness and diversity in Swiss municipalities: How does local autonomy influence transparency practices? International Review of Administrative Sciences, pp. 1-17.

Klein, R. H., Klein, D. C., \& Luciano, E. M. (2018). Identificação de mecanismos para a ampliação da transparência em portais de dados abertos: uma análise no contexto brasileiro. FGV EBAPE, pp. 692-715.

Kornberger, M., Meyer, R. E., Brandtner, C., \& Höllerer, M. A. (2017). When Bureaucracy Meets the Crowd: Studying "Open Government" in the Vienna City Administration. Organization Studies, pp. 38(2), 179-200.

Kowal, S., \& O'Connell, D. (2014). Transcription as a Crucial Step of Data Analysis. In Flick, U (Ed.). The SAGE handbook of qualitative data analysis. (pp. 64-78). SAGE Publications Ltd.

Koznov, D., Andreeva, O., Nikula, U., Maglyas, A., Muromtsev, D., \& Radchenko, I. (2016). A survey of open government data in Russian Federation. IC3K 2016Proceedings of the 8th international joint conference on knowledge discovery, knowledge engineering and knowledge management, pp. 3. 173-180. 
Lacharite, J. R. (2011). The Internet and electronic democracy in Canada: Reaching the limits of e-government and the false promise of digital democracy? Canadian Political Science Review, pp. 5(1), 1-19.

Lannon, J., \& Walsh, J. (2020). Paradoxes and partnerships: a study of knowledge exploration and exploitation in international development programmes. Journal of Knowledge Management, pp. 24,(1), 8-31.

Leech, B. L. (2002). Asking questions: Techniques for semistructured interviews. Political Science \& Politics, pp. 35, 665-668.

Lei Complementar n. 101, de 4 de maio de 2.000. Estabelece normas de finanças públicas voltadas para a responsabilidade na gestão fiscal e dá outras providências. (s.d.). Fonte: http://www.planalto.gov.br/ccivil_03/leis/LCP/Lcp101.htm

Lei complementar n. 131, de 27 de maio de 2.009. Acrescenta dispositivos à Lei Complementar no 101, de 4 de maio de 2000, que estabelece normas de finanças públicas voltadas para a responsabilidade na gestão fiscal e dá outras providências, a fim de dete. (s.d.). Fonte: Recuperado de http://www.planalto.gov.br/ccivil_03/LEIS/LCP/Lcp131.htm

Lei n 8.666, de 21 de junho de 1.933. nstitui normas para licitações e contratos da Administração Pública e dá outras providências. (s.d.). Fonte: http://www.planalto.gov.br/ccivil_03/leis/18666cons.htm

Lei n. 12.527, de 18 de novembro de 2.011. Regula o acesso a informações previsto no inciso XXXIII do art. $5^{\circ}$, no inciso II do $\S 3^{\circ}$ do art. 37 e no $\S 2^{\circ}$ do art. 216 da Constituição Federal; altera a Lei $n^{\circ}$ 8.112, de 11 de dezembro de 1990; revoga a Lei n. (s.d.). Fonte: Recuperado de http://www.planalto.gov.br/ccivil_03/_ato2011-2014/2011/Lei/L12527.htm

Leite Filho, G. A., Colares, A. F., \& Andrade, I. C. (2015). Transparência da gestão físcal pública: um estudo a partir dos portais eletrônicos dos maiores municípios do estado de minas gerais. Revista Contabilidade Vista \& Revista, pp. 26(2), 114136.

Leite Filho, G. A., Colares, A. F., \& Andrade, I. C. (2015). Transparência da Gestão Fiscal Pública: um estudo a partir dos portais eletrônicos dos maiores municípios do estado de Minas Gerais. Contabilidade Vista \& Revista, pp. 26(2), 114-136.

Leonardi, P. M., Treem, J. W., \& Jackson, M. H. (2010). The connectivity paradox: Using technology to both decrease and increase perceptions of distance in distributed work arrangements. Journal of Applied Communication Research, pp. 38(1), 85105.

Lewis, M. W. (2000). Exploring paradox: Toward a more comprehensive guide. Academy of Management Review, pp. 25(4), 760-776.

Lima Filho, S. S., Martins, G. D., \& Peixe, B. C. (2021). Compras públicas para enfrentamento da Covid-19: uma análise sob a lente da teoria contingencial. Revista Contemporânea de Contabilidade, pp. 18, 48, 40-55. 
Lin, H., Qu, T., Li, L., \& Tian, Y. (2019). The paradox of stability and change: a case study. Chinese Management Studies, pp. 14,(1),185-213.

Lindquist, E. A., \& Huse, I. (2017). Accountability and monitoring government in the digital era: Promise, realism and research for digital-era governance. Canadian Public Administration, pp. 60(4), 627-656.

Lindqvist, K. (2019). Dilemmas and paradoxes of regional cultural policy implementation governance modes, discretion, and policy outcome. Administration \& Society, pp. 51(1), 63-90.

Lopes, I., \& Santos, T. (2020). Transformações da sociedade contemporânea consubstanciadas na pandemia da covid-19 e trajetória profissional de sujeitos em espaços contábeis. Congresso USP, São Paulo.

Loureiro, M., Teixeira, M., \& Prado, O. (2008). Construção de instituições democráticas no Brasil contemporâneo: transparência das contas. . Revista Organização \& Sociedade, pp. 15, (47), 107-119.

Luciano, E. M., Wiedenhöft, G. C., \& Santos, F. P. (2018). Barreiras para a ampliação de transparência na administração pública brasileira: questões estruturais e culturais ou falta de estratégia e governança? Administração Pública e Gestão Social, pp. 10(4), 282-291.

Luiz, P. (2020). Os impactos do Coronavírus nas compras públicas. Fonte: Conlicitação: https://portal.conlicitacao.com.br/plantao-coronavirus/covid-19-e-aslicitacoes/os-impactos-do-coronavirus-nas-compras-publicas/

Lyrio, M., Santos, G., Rosa, R., \& Ferreira, L. (2020). Enfrentamento da COVID-19 em Santa Catarina: resultados da implementação de uma metodologia para aprimoramento da transparência e abertura de dados. Congresso USP, São Paulo.

Mahler, J., \& Regan, P. (2006). Crafting the message: controlling content on agency web sites. Government Information Quarterly, pp. (24) 505-521.

Maia, A., Costa, Y., Santos, A., Nascimento, I., \& Melo, G. (2020). Transparência dos dados de dispensa de licitação para combate à covid-19. Congresso USP. São Paulo.

Marangoni, A. (2020). 18 prefeitos contrariam Doria e não fecham comércio. Fonte: Revista Isto É: https://revistaoeste.com/politica/18-prefeitos-contrariam-doria-enao-fecham-comercio/

Mazmanian, M., Orlikowski, W. J., \& Yates, J. (2013). The autonomy paradox: The implications of mobile email devices for knowledge professionals. Organization Science, pp. 24(5), 1337-1357.

McDermott, P. (2010). Building open government. Government Information Quarterly, pp. 27(4), 401-413.

Medeiros, F. (2019). Fonte: Terceirização aumenta em 2018, aponta pesquisa: Recuperado de https://www.mazzini.com.br/blog/terceirizacao-aumenta-em2018-aponta-pesquisa/ 
Medida Provisória ${ }^{\circ}$ 928, de 2020, altera a Lei $n^{\circ} 13.979$, de 6 de fevereiro de 2020, que dispõe sobre as medidas para enfrentamento da emergência de saúde pública de importância internacional decorrente do coronavírus responsável pelo surto de 2019, e re. (2020). Fonte: Congresso Nacional: https://www.congressonacional.leg.br/materias/medidas-provisorias/$/ \mathrm{mpv} / 141147$

Meijer, A. J. (2013). Understanding the complex dynamics of transparency. Public Administration Review, pp. 73(3): 429-39.

Meireles, E. (2001). Funções do Ssndicato (das entidades sindicais). Revista LTr, , pp. 65, 299-307.

Michener, G. (2019). Gauging the Impact of Transparency Policies. Public Administration Review, pp. 79, (1), 136-39.

Michener, G., Contreras, E., \& Niskier, I. (2018). From Opacity to Transparency? Evaluating Access to Information in Brazil Five Years Later. Revista de Administração Pública, pp. 52(4), 610-29.

Mileski, H. S. (2007). Tribunal de contas: evolução, natureza, funções, perspectivas futuras. Interesse Público: Revista de Direito Público, pp. 9(45), 267-279.

Millard, J. (2015). Open governance systems: Doing more with more. Government information quarterly, pp. 1-1.

Moraes, R. (1999). Análise de conteúdo. Revista Educação, pp. 22, (37), 7-32.

Morais, H. D. (2020). Operação sevandija: um estudo das causas e consequências da corrupção. Revista Jurídica da Escola Superior do Ministério Público de São Paulo, pp. 17, 1, 157-170.

Moreira, A., \& Pinheiro, L. (2020). OMS declara pandemia de coronavírus. Fonte: G14: Recuperado https:/g1.globo.com/bemestar/coronavirus/noticia/2020/03/11/oms-declarapandemia-de-coronavirus.ghtml

Motta, F. (2019). Despesas com pessoal e criatividade contábil. Fonte: Consultor Jurídico: Recuperado de https:/www.conjur.com.br/2019-dez-05/interessepublico-despesas-pessoal-criatividade-contabil

Mozzato, A. R., \& Grzybovski, D. (2011). Análise de conteúdo como técnica de análise de dados qualitativos no campo da administração: potencial e desafios. Revista de Administração Contemporânea, pp. 15, (4), 731-747.

Nascimento, T. (2020). Governo do RJ gasta R\$ 1 bilhão em contratos sem licitação para combate à Covid-19. Fonte: G1: https://g1.globo.com/rj/rio-dejaneiro/noticia/2020/04/10/governo-do-rj-gasta-r-1-bilhao-em-contratos-semlicitacao-para-combate-a-covid-19.ghtml

Neves, F. R., \& Silva, P. B. (2021). E-government em portais públicos de municípios: do visível para o invisível. Revista Catarinense da Ciência Contábil, pp. 20, 1-22. 
Nikiforova, A., \& McBride, K. (2021). Open government data portal usability: A usercentered usability analysis of 41 open government data portals. Telematics and Informatics, p. 58.

O'Connell, D. (2016). Risk management: Transaction cost economics, outsourcing and corruption prevention. Governance Directions, pp. 68(11), 658-662.

Orlikowski, W. J. (2000). Using Technology and Constituting Structures: A Practice Lens for Studying Technology in Organizations. Organization Science, pp. 11(4):404428.

Pang, A., Cropp, F., \& Cameron, G. T. (2006). Corporate crisis planning: Tensions, issues, and contradictions. Journal of Communication Management, pp. 10(4), 371-389.

Passarinho, N. (2019). Fiscalização de barragens: órgão federal de controle é o $2^{\circ}$ mais exposto a fraudes e corrupção, diz TCU. Fonte: BBC News Brasil: https://www.bbc.com/portuguese/brasil-47211131

Patton, M. Q. (2015). Qualitative Research \& Evaluation Methods - Integrating Theory and Practice. SAGE Publications Ltd.

Peron, I. (2020). PF deflagra operação contra compra irregular de livros sobre covid-19 na $\quad P B$. Fonte: Valor Econômico: Recuperado de https://valor.globo.com/brasil/noticia/2020/04/23/pf-deflagra-operacao-contracompra-irregular-de-livros-sobre-covid-19.ghtml

Pinho, J. A. (2008). Investigando portais de governo eletrônico de estados no Brasil: muita tecnologia e pouca democracia. Revista de Administração Pública, pp. 42(3), 471-493.

Platt Neto, O. A., Cruz, F., \& Vieira, A. L. (2006). Transparência das contas públicas: um enfoque no uso da internet como instrumento de publicidade na UFSC. Revista Contemporânea de Contabilidade, pp. 1(5), 135-146.

Platt Neto, O. A., Cruz, F., Ensslin, S. R., \& Ensslin, L. (2007). Publicidade e Transparência das Contas Públicas: obrigatoriedade e abrangência desses princípios na administração pública brasileira. Contabilidade Vista \& Revista, pp. 18(1), 75-94.

Poole, M. S., \& van de Ven, A. H. (1989). Using Paradox to Build Management and Organization Theories. Academy of Management Review, pp. 14(4), 562-578.

Portal de Compras. (2021). Transparência dos dados de Dispensa para o COVID-19. Fonte: Portal de Compras Governo Federal: Recuperado de https://www.gov.br/compras/pt-br/painel-covid

Pozen, D. (2020). Seeing Transparency more Clearly. Public Administration Review, pp. 80(2), 326-33.

Pradies, C., Tunarosa, A., Lewis, M. W., \& Courtois, J. (2020). From vicious to virtuous paradox dynamics: The social-symbolic work of supporting actors. Organization Studies, pp. 1-23. 
Prado, O., \& Loureiro, M. R. (2006). Governo eletrônico, transparência e democracia: a publicização das contas públicas das capitais brasileiras. Revista Alcance, p. 13(3).

Precinotto, A., Dias, L. N., \& Aquino, A. C. (2020). Paradoxos na divulgação de salários em governos locais. Congresso USP. São Paulo.

Prefeitura de Jundiaí. (2020). Contratações - Coronavírus. Fonte: Prefeitura de Jundiaí: https://transparencia.jundiai.sp.gov.br/contratacoes-coronavirus/

Prefeitura de Ribeirão Preto/SP. (2020). Licitações - COVID-19 (Novo Coronavírus). Fonte: Prefeitura de Ribeirão Preto/SP: Recuperado de https://www.ribeiraopreto.sp.gov.br/portal/transparencia/licitacoes-covid-19

Putnam, L. L., Fairhurst, G. T., \& Banghart, S. (2016). Contradictions, Dialectics, and Paradoxes in Organizations: A Constitutive Approach. Academy of Management Annals, pp. 10(1), 65-171.

R7. (2020). Cidades de SP montam hospitais de campanha para combate à covid-19. Fonte: R7: Recuperado de https://noticias.r7.com/sao-paulo/cidades-de-spmontam-hospitais-de-campanha-para-combate-a-covid-19-03042020

Raza-Ullah, T., Bengtsson, M., \& Kock, S. (2014). The coopetition paradox and tension in coopetition at multiple levels. Industrial Marketing Management, pp. 43(2), 189-198.

Ribeiro, M. M. (2009). Usando a internet para a promoção da transparência: os portais na América Latina. XIV Congreso Internacional del CLAD sobre la Reforma del Estado y de la Administración Pública. Salvador.

Rigolin, I. B. (2016). Publicações necessárias em licitação e contrato. Fonte: Acopesp: Recuperado de http://www.acopesp.org.br/admin/assets/arquivos/cdfe2c96ad8eb6eda809e772f9 0f8dfd.pdf

Rocha, L. A., \& Valadares, M. G. (2019). A possiblidade da terceirização da atividadefim: aspectos e impactos nos trabalhadores. Revista do Direito do Trabalho e Meio Ambiente do Trabalho, pp. 5(1), 59- 79.

Rowley, J. (2011). E-government stakeholders - Who are they and what do they want? International Journal of Information Management, , pp. 31(1), 53-62.

Roy, J. (2014). Open data and open governance in Canada: A critical examination of new opportunities and old tensions. Future Internet, pp. 6, 414-32.

Sales, T. (2012). Acesso à Informação, Controle Social das Finanças Públicas e Democracia: Análise dos Portais da Transparência dos Estados Brasileiros Antes e Após o Advento da Lei no 12.527/2011. Direito Público, p. 9 (48).

Sandes, A. (2020). Puxado por SP e BA, Brasil tem maior alta de casos de covid-19 em 24 horas. Fonte: Uol: Recuperado de https://noticias.uol.com.br/saude/ultimasnoticias/redacao/2020/05/28/brasil-recorde-covid-19.htm 
Sandoval-Almazán, R. (2015). Open government and transparency: building a conceptual framework. Convergencia, Revista de Ciencias Sociales, pp. 68, 41-46.

Sandoval-Almazán, R., \& Gil-Garcia, J. R. (2012). Are government internet portals evolving towards more interaction, participation, and collaboration? Revisiting the rhetoric of e-government among municipalities. Government Information Quarterly, pp. 29, S72-S81.

Scatolino, G. (2018). Uma análise objetiva do decreto n. 9.507 e seu impacto nos concursos públicos. Fonte: Gran Cursos Online: Recuperado em https://blog.grancursosonline.com.br/decreto-9-507-concursos/

Schad, J., Lewis, M. W., Raisch, S., \& Smith, W. K. (2016). Paradox Research in Management Science: Looking Back to Move Forward. The Academy of Management Annals, pp. 10(1), 5-64.

Schnel, S. (2018). From information to predictability: transparency on the path to democratic governance. The case of Romania. International Review of Administrative Sciences, pp. 84(4), 692-710.

Secretaria de Estado de Saúde de Goiás. (2020). Calendário Epidemiológico. Fonte: https://www.saude.go.gov.br/acesso-a-informacao/712suvisa/vigil\%C3\%A2ncia-epidemiol\%C3\%B3gica/8412-calendarioepidemiologico

Sediyama, G. A., Anjos, D. A., \& Felix, E. M. (2018). Transparência pública municipal: uma análise dos municípios mineiros que decretaram calamidade financeira. Gestão \& Regionalidade, pp. 35(104), 201-218.

Selting, M.; Auer, P.; Barth-Weingarten; D., Bergmann, J.; Bergmann, P.; Birkner, K.; et al. (2011). A system for transcribing talk-in-interaction: GAT 2. Transl. E. Couper-Kuhlen \& D. BarthWeingarten. Gesprächsforschung, pp. 12, 1-51.

Silva, A. (2017). As implicações da terceirização na administração pública brasileira. Revista Conbrad, pp. 2(1), 109-124.

Silva, J. M., Cristovan, P. F., Cavalcante, L. F., \& Vechiato, F. L. (2019). Encontrabilidade e Usabilidade da Informação no Portal da Transparência do Poder Executivo Federal. Colóquio em Organização, Acesso e Apropriação da Informação e do Conhecimento.

Silva, R. (2020). Oposição e sindicatos irão à Justiça contra projeto de terceirização de Ratinho. Fonte: Plural: Recuperado de: https://www.plural.jor.br/noticias/poder/oposicao-e-sindicatos-irao-a-justicacontra-projeto-de-terceirizacao-de-ratinho/

Silva, T., Cunha, M. P., Clegg, S. R., Neves, P., Rego, A., \& Rodrigues, R. A. (2014). Smells like team spirit: Opening a paradoxical black box. Human Relations, pp. 67(3), 287-310.

Sintieftal. (2018). Temer decreta terceirização da atividade-fim no serviço público. Fonte: Sindicato dos Servidores Públicos Federais da Educação Básica e 
Profissional no Estado de Alagoas: Recuperado de http://www.sintietfal.org.br/2018/09/temer-decreta-terceirizacao-da-atividadefim-no-servico-publico/

Smith, W. K., \& Lewis, M. W. (2011). Toward a theory of paradox: A dynamic equilibrium model of organizing. Academy of Management Review, pp. 36(2), 381-403.

Souza, R. J., Barbosa, R. B., Cabral, A. C., \& Santos, S. M. (2019). Avaliação da Qualidade das Informações disponibilizadas no Portal da Transparência do Estado do Ceará. Encontros Bibli, pp. 24(54), 91-104.

Supremo Tribunal Federal. (2020). Plenário confirma liminar que impediu restrições na Lei de Acesso à Informação durante pandemia. Fonte: Supremo Tribunal Federal: Recuperado de http://portal.stf.jus.br/noticias/verNoticiaDetalhe.asp?idConteudo=442475\&ori= 1

Transparência Internacional. (2020). Ranking de transparência no combate à covid-19. Fonte: Transparência Internacional: https://transparenciainternacional.org.br/ranking/\#ranking

Transparência Internacional. (2020). Recomendações para transparência de contratações emergenciais em resposta à covid-19. Fonte: Transparência Internacional: https://comunidade.transparenciainternacional.org.br/asset/86:tibrrecomendacoes-de-contratacoes-emergenciais-covid19? stream $=1$

Tribunal de Contas do Estado de São Paulo. (2019). 1/3 dos municípios tem gastos excessivos com pessoal; 73\% tem problemas orçamentários. Fonte: Recuperado de https://www.tce.sp.gov.br/6524-13-municipios-tem-gastos-excessivos-compessoal-73-tem-problemas-orcamentarios

Tribunal de Contas do Estado de São Paulo. (2020). Comunicado SDG $n^{\circ} 14 / 2020$. Fonte: Tribunal de Contas do Estado de São Paulo: Recuperado de https://www.tce.sp.gov.br/sites/default/files/noticias/ComunicadoSDG142020.p df

Tribunal de Contas do Estado de São Paulo. (2020). Comunicado SDG $n^{\circ} 17 / 2020$. Fonte: Tribunal de Contas do Estado de São Paulo: https://www.tce.sp.gov.br/sites/default/files/legislacao/COMUNICADO\%20SD G\%20\%2017\%202020.pdf

Tribunal de Contas do Estado de São Paulo. (2020). Uma entre 4 Prefeituras fecha 2019 com gasto excessivo com pessoal. Fonte: Recuperado de https://www.tce.sp.gov.br/6524-entre-4-prefeituras-fecha-2019-com-gastoexcessivo-com-pessoal

Tribunal de Contas do Estado de São Paulo. (2021). TCE detecta irregularidades em mais de 20\% dos Portais de Transparência. Fonte: https://www.tce.sp.gov.br/6524tce-detecta-irregularidades-mais-20-portais-transparencia 
Tribunal de Contas do Estado do Rio de Janeiro. (s.d.). TCE-RJ aprova nota técnica sobre medidas para emergência de saúde pública. Fonte: Tribunal de Contas do Estado do Rio de Janeiro: https://www.tce.rj.gov.br/comunicados-covid-19//asset_publisher/fUX2cCZjHu91/content/tce-rj-aprova-nota-tecnica-sobremedidas-para-emergencia-de-saude-publica

Tuckermann, H. (2018). Visibilizing and invisibilizing paradox: A process study of interactions in a hospital executive board. Organization Studies, pp. 40, 18511872.

TV Bahia. (2020). Advogado que defende vítimas de suposto esquema de contratações irregulares por prefeitura na BA relata ter sido ameaçado de morte. Fonte: G1: Recuperado de: https://g1.globo.com/ba/bahia/noticia/2020/08/14/advogado-quedefende-vitimas-de-suposto-esquema-de-contratacoes-irregulares-por-prefeiturana-ba-relata-ter-sido-ameacado-de-morte.ghtml

Tye-Williams, S., \& Krone, K. J. (2017). Identifying and re-imagining the paradox of workplace bullying advice. . Journal of Applied Communication Research, pp. 45(2), 218-235.

Van den Brink, M., \& Stobbe, L. (2009). Doing gender in academic education: The paradox of visibility. Gender, Work and Organization, pp. 16(4), 451-470.

Van Helvert-Beugels, J., Nordqvist, M., \& Flören, R. (2020). Managing tensions as paradox in CEO succession: The case of nonfamily CEO in a family firm. International Small Business Journal: Researching Entrepreneurship, pp. 38(3), 211-242.

Vieira, B. (2020). Consulta. Pandemia. Covid 19. Contratações em curso na área de educação. Terceirizações. Atividades meio. Transporte escolar. Suspensão das aulas. Fonte: Tribunal de Contas dos Municípios do Estado da Bahia: Recuperado de: https://www.tcm.ba.gov.br/wp-content/uploads/2020/05/aju-consultacanavieiras-06213e20-contratacoes-em-curso-na-area-de-educacaoterceirizacoes-atividades-meio-transporte-escolar-suspensao-das-aulaspagamento.pdf

Wagner, A. J. (2017). Essential or extravagant: Considering FOIA budgets, costs and fees. Government Information Quarterly, pp. 34(3), 388-395.

Wang, V., \& Shepherd, D. (2019). Exploring the extent of openness of open government data - A critique of open government datasets in the UK. Government Information Quarterly, pp. 37(1), 1-10.

Wong, C. M., \& Jensen, O. (2020). The Paradox of Trust: Perceived Risk and Public Compliance during the COVID-19 Pandemic in Singapore. Journal of Risk Research, pp. 1-10.

Wong, W., \& Welch, E. (2004). Does e-government promote accountability? A comparative analysis of website openness and government accountability. Governance, pp. 17(2), 275-97.

Yin, R. K. (2001). Estudo de caso: planejamento e métodos. 2ed. Porto Alegre: Bookman. 
Zuccolotto, R., \& Teixeira, M. (2014). As causas da transparência fiscal: evidências nos estados brasileiros. Revista Contabilidade \& Finanças, pp. 25, (66), 242-254.

Zuccolotto, R., \& Teixeira, M. A. (2017). Transparência orçamentária: razões do descompasso entre os estados brasileiros. Organizações \& Sociedade, pp. 24(82), $390-411$. 
APÊNDICE A - Estudos empíricos open government e transparência

\begin{tabular}{|c|c|c|c|c|c|c|}
\hline Autor (Ano) & $\begin{array}{c}\text { Tipo de } \\
\text { Abertura }\end{array}$ & $\begin{array}{c}\text { Stakeholders } \\
\text { (empiricamente } \\
\text { discutidos) }\end{array}$ & $\begin{array}{l}\text { Contexto (país, } \\
\text { tipo de } \\
\text { organização) } \\
\text { /Amostra } \\
\end{array}$ & Questão Problema & Método & $\begin{array}{l}\text { Principais Resultados } \\
\text { Empíricos }\end{array}$ \\
\hline $\begin{array}{l}\text { Grimmelikhuijsen } \\
\& \text { Feeney (2017) }\end{array}$ & $\begin{array}{c}\text { Transparência } \\
\text { ativa }\end{array}$ & $\begin{array}{l}\text { Governos locais; } \\
\text { gestores públicos }\end{array}$ & EUA, 500 cidades & $\begin{array}{c}\text { Fatores } \\
\text { organizacionais } \\
\text { (estrutura, ambiente e } \\
\text { contexto) que afetam } \\
\text { a abertura de } \\
\text { governos }\end{array}$ & $\begin{array}{l}\text { Análise de conteúdo de } \\
\text { dados de websites de } \\
\text { prefeituras. Regressão } \\
\text { linear com base nas } \\
\text { respostas de survey enviada } \\
\text { para chefes de } \\
\text { departamentos. }\end{array}$ & $\begin{array}{c}\text { Combinações de fatores } \\
\text { promovem as dimensões } \\
\text { (transparência, acessibilidade } \\
\text { e participação) do governo } \\
\text { aberto. }\end{array}$ \\
\hline $\begin{array}{l}\text { Chatwin et al. } \\
\text { (2019) }\end{array}$ & $\begin{array}{c}\text { Transparência } \\
\text { ativa }\end{array}$ & $\begin{array}{c}\text { Governos locais e } \\
\text { estaduais }\end{array}$ & $\begin{array}{c}\text { Ásia, África, } \\
\text { Europa, América } \\
\text { do Sul, América } \\
\text { do Norte; } \\
\text { Governos } \\
\text { estaduais e locais } \\
\text { da } \\
\end{array}$ & $\begin{array}{l}\text { Conceitualização de } \\
\text { governo aberto em } \\
\text { nível subnacional }\end{array}$ & $\begin{array}{l}\text { Análise de conteúdo de } \\
\text { documentos com planos de } \\
\text { ação para abertura do } \\
\text { governo }\end{array}$ & $\begin{array}{l}\text { Em geral, há semelhança na } \\
\text { adoção dos princípios de } \\
\text { governos abertos, mas o } \\
\text { contexto local influencia o } \\
\text { desenvolvimento de } \\
\text { mecanismos diferentes }\end{array}$ \\
\hline $\begin{array}{l}\text { Kornberger et al. } \\
\text { (2017) }\end{array}$ & $\begin{array}{l}\text { Transparência } \\
\text { ativa; Dados } \\
\text { abertos }\end{array}$ & $\begin{array}{l}\text { Governo local; } \\
\text { gestores públicos; } \\
\text { cidadãos }\end{array}$ & Viena, Austria & $\begin{array}{l}\text { Conflito de princípios } \\
\text { entre burocracia e } \\
\text { governo aberto }\end{array}$ & $\begin{array}{l}\text { Codificação e análise de } \\
\text { narrativa das entrevistas } \\
\text { com gestores públicos }\end{array}$ & $\begin{array}{l}\text { Identificação de demagogia } \\
\text { nas questões de abertura dos } \\
\text { governos. No entanto, tal } \\
\text { processo possibilitou o } \\
\text { aumento de investimentos } \\
\text { internos e criou capital social, } \\
\text { humano e cultural }\end{array}$ \\
\hline Altayar (2018) & $\begin{array}{l}\text { Transparência } \\
\text { ativa; Dados } \\
\text { abertos }\end{array}$ & $\begin{array}{l}\text { Gestores e } \\
\text { especialistas de } \\
\text { Ministérios de } \\
\text { Governo Central }\end{array}$ & $\begin{array}{l}\text { Arábia Saudita, } 50 \\
\text { funcionários de } \\
\text { cinco Ministérios } \\
\text { (TI, comércio, } \\
\text { educação, ciência, } \\
\text { informação e } \\
\text { serviços) do } \\
\text { Governos Central }\end{array}$ & $\begin{array}{l}\text { Razões e benefícios } \\
\text { para adoção }\end{array}$ & $\begin{array}{c}\text { Entrevistas com } 50 \\
\text { funcionários diretores; } \\
\text { documentos; e portal de } \\
\text { dados de governos. Análise } \\
\text { qualitativa. }\end{array}$ & $\begin{array}{c}\text { Ministérios ainda não } \\
\text { compreendem conceito de } \\
\text { OGD } \\
\text { Regulação afeta adoção do } \\
\text { OGD. Pressões institucionais } \\
\text { internas e externas } \\
\text { influenciam o processo de } \\
\text { abertura de dados }\end{array}$ \\
\hline
\end{tabular}




\begin{tabular}{|c|c|c|c|c|c|c|}
\hline $\begin{array}{l}\text { Gascó-Hernández } \\
\text { et al. (2018) }\end{array}$ & $\begin{array}{l}\text { Transparência } \\
\text { ativa; Dados } \\
\text { abertos }\end{array}$ & $\begin{array}{l}\text { Cidadãos e } \\
\text { estudantes de nível } \\
\text { médio e superior }\end{array}$ & $\begin{array}{c}\text { Alunos de pós } \\
\text { graduação em } \\
\text { administração } \\
\text { pública dos EUA; } \\
\text { estudantes de } \\
\text { ensino médio da } \\
\text { Itália; cidadãos da } \\
\text { Espanha } \\
\text { interessados em } \\
\text { utilizar dados } \\
\text { públicos }\end{array}$ & $\begin{array}{c}\text { Capacitação para } \\
\text { usuários de dados } \\
\text { abertos }\end{array}$ & $\begin{array}{l}\text { Entrevistas com cidadãos, } \\
\text { alunos de ensino médio, } \\
\text { pós-graduação ensino } \\
\text { médio; e cidadãos } \\
\text { espanhóis. } \\
\text { Documentos e conteúdo de } \\
\text { sites dos cursos oferecidos. }\end{array}$ & $\begin{array}{c}\text { Necessidade de } \\
\text { aprimoramento e adaptação } \\
\text { de capacitações para } \\
\text { incentivar o uso de dados } \\
\text { abertos }\end{array}$ \\
\hline $\begin{array}{l}\text { Wang \& Shepherd, } \\
\text { (2019) }\end{array}$ & $\begin{array}{l}\text { Transparência } \\
\text { ativa; Dados } \\
\text { abertos }\end{array}$ & $\begin{array}{l}\text { Governo Central; } \\
\text { cidadãos }\end{array}$ & $\begin{array}{l}\text { Governo Central } \\
\text {,Reino Unido }\end{array}$ & $\begin{array}{l}\text { Grau da abertura dos } \\
\text { dados abertos }\end{array}$ & $\begin{array}{c}\text { Análise do grau de abertura } \\
\text { a ser verificado por } \\
\text { cidadãos comuns. } \\
136 \text { bases de dados que } \\
\text { consideraram a } \\
\text { popularidade e dos dados } \\
\text { no site data.gov.uk; e } 264 \\
\text { bases que não consideraram } \\
\text { tal }\end{array}$ & $\begin{array}{c}\text { As bases de dados não são } \\
\text { voltadas para que cidadão } \\
\text { comuns possam verificá-las. } \\
65 \% \text { das bases de dados são } \\
\text { agregadas e não granulares. } \\
38 \% \text { dados antigos; } \\
30 \% \text { não estão totalmente } \\
\text { acessíveis }\end{array}$ \\
\hline $\begin{array}{c}\text { Nikiforova \& } \\
\text { McBride (2021) }\end{array}$ & $\begin{array}{l}\text { Transparência } \\
\text { ativa; Dados } \\
\text { abertos }\end{array}$ & $\begin{array}{l}\text { Governo Central; } \\
\text { cidadãos }\end{array}$ & $\begin{array}{c}\text { Governos } \\
\text { nacionais da } \\
\text { Europa e Ásia }\end{array}$ & $\begin{array}{c}\text { Avaliação e } \\
\text { comparação entre } \\
\text { funcionalidade de } \\
\text { dados abertos e } \\
\text { contextos }\end{array}$ & $\begin{array}{c}\text { Análise baseada em } \\
\text { categorias e critérios de } \\
\text { funcionalidade em portais } \\
\text { de dados abertos de } 41 \\
\text { países }\end{array}$ & $\begin{array}{c}\text { Boa implementação de } \\
\text { aspectos técnicos e } \\
\text { deficiência na implantação de } \\
\text { aspectos menos técnicos } \\
\text { destinados a usuários em } \\
\text { geral } \\
\end{array}$ \\
\hline Schnell (2018) & $\begin{array}{l}\text { Transparência } \\
\text { ativa e passiva; } \\
\text { Dados abertos; } \\
\text { participação } \\
\text { social }\end{array}$ & $\begin{array}{l}\text { Governo Central; } \\
\text { gestores públicos }\end{array}$ & $\begin{array}{c}\text { Governo Central } \\
\text { em processo de } \\
\text { democratização, } \\
\text { Romênia }\end{array}$ & $\begin{array}{c}\text { Evolução da } \\
\text { transparência e o } \\
\text { desenvolvimento da } \\
\text { democracia }\end{array}$ & $\begin{array}{l}\text { Documentos públicos sobre } \\
\text { transparência; entrevistas } \\
\text { com agentes e ex agentes } \\
\text { do governo e demais atores } \\
\text { envolvidos no } \\
\text { desenvolvimento e } \\
\text { implantação da } \\
\text { transparência. }\end{array}$ & $\begin{array}{l}\text { A evolução da transparência é é } \\
\text { observada na relevância dada } \\
\text { ao tema em discursos } \\
\text { públicos e no número } \\
\text { crescente de atos que tratam } \\
\text { do assunto. } \\
\text { No entanto, a publicação de } \\
\text { informações de qualidade e } \\
\text { transparência participativa } \\
\text { precisam ser desenvolvidas }\end{array}$ \\
\hline
\end{tabular}




\begin{tabular}{|c|c|c|c|c|c|c|}
\hline $\begin{array}{c}\text { Keuffer \& } \\
\text { Mabillard (2019) }\end{array}$ & $\begin{array}{c}\text { Transparência } \\
\text { ativa }\end{array}$ & $\begin{array}{l}\text { Governos locais, } \\
\text { gestores públicos }\end{array}$ & $\begin{array}{l}\text { Suíça, } 16 \\
\text { municípios }\end{array}$ & & & $\begin{array}{c}\text { práticas de transparência } \\
\text { divergem acentuadamente } \\
\text { entre os municípios suíços e, } \\
\text { por outro, que a autonomia } \\
\text { influencia o grau de } \\
\text { transparência no nível local }\end{array}$ \\
\hline Klein et al. (2018) & $\begin{array}{l}\text { Transparência } \\
\text { ativa; Dados } \\
\text { abertos }\end{array}$ & $\begin{array}{l}\text { Governo Central; } \\
\text { especialistas em } \\
\text { transparência; } \\
\text { observatórios } \\
\text { sociais; entidades } \\
\text { de ativismo social; } \\
\text { Grupo de rede } \\
\text { social }\end{array}$ & $\begin{array}{l}\text { Brasil, Portal de } \\
\text { dados abertos do } \\
\text { Governo Federal }\end{array}$ & $\begin{array}{l}\text { Mecanismos que } \\
\text { ampliam dados } \\
\text { abertos }\end{array}$ & $\begin{array}{l}\text { Revisão de literatura; } \\
\text { entrevistas e discussões } \\
\text { com especialistas; } \\
\text { levantamento eletrônico } \\
\text { com usuários de OGD. }\end{array}$ & $\begin{array}{l}\text { Identificação de mecanismos } \\
\text { que aumentam a transparência } \\
\text { de forma a atender as } \\
\text { demandas de usuários de } \\
\text { informações governamentais } \\
\text { (cidadãos; organizações } \\
\text { sociais; entidades } \\
\text { fiscalizadoras) }\end{array}$ \\
\hline $\begin{array}{l}\text { Luciano et al. } \\
\quad \text { (2018) }\end{array}$ & $\begin{array}{c}\text { Transparência } \\
\text { ativa e passiva; } \\
\text { Dados abertos; } \\
\text { participação } \\
\text { social }\end{array}$ & $\begin{array}{l}\text { Unidade da } \\
\text { Federação; } \\
\text { gestores públicos }\end{array}$ & $\begin{array}{l}\text { Brasil, Unidade da } \\
\text { Federação não } \\
\text { especificada }\end{array}$ & $\begin{array}{l}\text { Barreiras e estratégias } \\
\text { em transparência } \\
\text { pública e governança } \\
\text { digital }\end{array}$ & $\begin{array}{l}\text { Categorização e análise de } \\
\text { conteúdo das entrevistas } \\
\text { com gestores públicos }\end{array}$ & $\begin{array}{l}\text { Barreiras: sentimento de } \\
\text { domínio da informação por } \\
\text { parte do governo; qualidade } \\
\text { ou falta da informação são } \\
\text { prejudiciais tanto para a } \\
\text { comunidade quanto para os } \\
\text { responsáveis por sua } \\
\text { divulgação. }\end{array}$ \\
\hline $\begin{array}{l}\text { Michener et al. } \\
\text { (2018) }\end{array}$ & $\begin{array}{l}\text { Transparência } \\
\text { passiva }\end{array}$ & $\begin{array}{l}\text { Governo Central, } \\
\text { governos estaduais } \\
\text { e locais; gestores } \\
\text { públicos; políticos }\end{array}$ & $\begin{array}{l}\text { Brasil, Governo } \\
\text { Federal; Unidades } \\
\text { Federativas e } \\
\text { capitais estaduais }\end{array}$ & Desempenho da LAI & $\begin{array}{l}\text { Relatórios e estatísticas de } \\
\text { Ministério Público e } \\
\text { governos subnacionais e } \\
\text { Governo Federal; } \\
\text { entrevistas com políticos e } \\
\text { gestores públicos; base de } \\
\text { dados compartilhadas por } \\
\text { outros pesquisadores. } \\
\text { Exploração de variáveis }\end{array}$ & $\begin{array}{c}\text { Atendimento parcial da } \\
\text { legislação; } \\
\text { escassez de indicadores } \\
\text { governamentais sobre pedidos } \\
\text { de AI e órgãos de controle } \\
\text { designados; falhas na } \\
\text { implantação de plataformas } \\
\text { específicas para envio de } \\
\text { pedidos de AI }\end{array}$ \\
\hline
\end{tabular}




\begin{tabular}{l|l|l|l|l|l}
\hline & & & & & $\begin{array}{c}\text { associadas à capacidade de } \\
\text { resposta; análise de } \\
\text { precisão das respostas. }\end{array}$ \\
\hline
\end{tabular}

Fonte: Elaborado pelo autor 
APÊNDICE B - Estudos empíricos paradoxo

\begin{tabular}{|c|c|c|c|c|c|c|}
\hline Autor (Ano) & Tipo de Paradoxo & $\begin{array}{c}\text { Stakeholders } \\
\text { (empiricamente } \\
\text { discutidos) }\end{array}$ & $\begin{array}{l}\text { Contexto (país, } \\
\text { tipo de } \\
\text { organização) } \\
\text { /Amostra } \\
\end{array}$ & Questão Problema & Método & Principais Resultados \\
\hline Adu (2018) & $\begin{array}{c}\text { Ideais de direito à } \\
\text { informação } v s \text {. } \\
\text { Elementos prejudiciais } \\
\text { ao acesso à informação }\end{array}$ & $\begin{array}{c}\text { Governos de } \\
\text { países africanos; } \\
\text { cidadãos; mídias; } \\
\text { políticos }\end{array}$ & 20 países, África & $\begin{array}{l}\text { Implementação do } \\
\text { direito à informação } \\
\text { na África é um } \\
\text { paradoxo? }\end{array}$ & $\begin{array}{l}\text { Análise de documentos. } \\
\text { Comparação entre leis de } \\
\text { direito à informação e } \\
\text { eventos que prejudicam o } \\
\text { acesso à informação. }\end{array}$ & $\begin{array}{c}\text { Corrupção, os abusos dos } \\
\text { direitos humanos, a mídia } \\
\text { restritiva, a falta de pluralismo } \\
\text { da mídia, a negação do acesso à } \\
\text { informação, a falta de } \\
\text { transparência e } \\
\text { responsabilidade minam os } \\
\text { ideais da lei de direito à } \\
\text { informação. } \\
\end{array}$ \\
\hline $\begin{array}{l}\text { Drummond } \\
\quad(2008)\end{array}$ & $\begin{array}{l}\text { Paradoxo de Ícaro: } \\
\text { eficácia vs. inutilidade: } \\
\text { um sistema que } \\
\text { aumentou a } \\
\text { produtividade do } \\
\text { processamento de } \\
\text { sinistros no curto prazo } \\
\text { resultou em custos } \\
\text { mais altos e menor } \\
\text { satisfação do cliente no } \\
\text { longo prazo } \\
\end{array}$ & $\begin{array}{l}\text { Empresas } \\
\text { seguradoras; } \\
\text { gerentes; } \\
\text { supervisores; } \\
\text { responsáveis por } \\
\text { desenvolvimento } \\
\text { e manutenção de } \\
\text { sistemas }\end{array}$ & $\begin{array}{c}\text { Companhia de } \\
\text { seguros da Europa }\end{array}$ & $\begin{array}{l}\text { 1.Como se manifesta } \\
\text { o conflito entre teoria } \\
\text { adotada e teoria em } \\
\text { ação? } \\
\text { 2.Como este conflito } \\
\text { é resolvido? }\end{array}$ & $\begin{array}{c}\text { Estudo exploratório de } \\
\text { caso único. Triangulação } \\
\text { de dados coletados em } \\
\text { entrevistas, documental e } \\
\text { observação. }\end{array}$ & $\begin{array}{l}\text { Computadores podem se tornar } \\
\text { ineficazes quando o trabalho } \\
\text { complexo e diferenciado é } \\
\text { reduzido ao que uma máquina } \\
\text { pode suportar. A ineficácia } \\
\text { pode se manifestar com a } \\
\text { produção de círculos viciosos } \\
\text { que não são detectados por } \\
\text { medidas padrão de eficiência e } \\
\text { ainda mais prejudiciais por } \\
\text { serem consideradas normais. }\end{array}$ \\
\hline $\begin{array}{l}\text { Jarzabkowski } \\
\text { et al. (2013) }\end{array}$ & $\begin{array}{l}\text { Demandas regulatórias } \\
\text { vs. demandas do } \\
\text { mercado. Uma mesma } \\
\text { regulação com o } \\
\text { objetivo de garantir } \\
\text { mercado competitivo } \\
\text { se opunha ao } \\
\text { comportamento }\end{array}$ & $\begin{array}{c}\text { Gerentes; } \\
\text { empresas de } \\
\text { telecomunicações }\end{array}$ & $\begin{array}{l}\text { Empresa de } \\
\text { telecomunicações } \\
\text { europeia que } \\
\text { passou por grande } \\
\text { reestruturação em } \\
\text { resposta a uma } \\
\text { nova } \\
\text { regulamentação do } \\
\text { governo. }\end{array}$ & $\begin{array}{l}\text { 1. Como é construída } \\
\text { a relação entre } \\
\text { diferentes paradoxos? } \\
\text { 2. Como as diferentes } \\
\text { respostas ao paradoxo } \\
\text { moldam uma relação } \\
\text { entre os paradoxos à } \\
\text { medida que eles se }\end{array}$ & $\begin{array}{l}\text { Estudo de caso único, } \\
\text { longitudinal em tempo } \\
\text { real. Codificação das } \\
\text { observações (notas de } \\
\text { campo) de reuniões } \\
\text { (filmadas) e entrevistas }\end{array}$ & $\begin{array}{l}\text { Por meio das ações dos atores } \\
\text { envolvidos no processo de } \\
\text { reestruturação foram } \\
\text { observados quatro tipos de } \\
\text { respostas ao paradoxo (divisão, } \\
\text { supressão, oposição e ajuste) } \\
\text { que geram uma relação } \\
\text { repetitiva entre os paradoxos de }\end{array}$ \\
\hline
\end{tabular}




\begin{tabular}{|c|c|c|c|c|c|c|}
\hline & $\begin{array}{l}\text { competitivo deste } \\
\text { mesmo mercado }\end{array}$ & & & $\begin{array}{l}\text { desenvolvem ao } \\
\text { longo do tempo? }\end{array}$ & & $\begin{array}{l}\text { organização, pertencimento e } \\
\text { desempenho. }\end{array}$ \\
\hline Jay (2012) & $\begin{array}{l}\text { Paradoxo do serviço. } \\
\text { Este paradoxo } \\
\text { promove mudanças } \\
\text { organizacionais que } \\
\text { prejudicam e } \\
\text { possibilitam ações } \\
\text { inovadoras. }\end{array}$ & $\begin{array}{l}\text { Organizações } \\
\text { híbridas; } \\
\text { organizações sem } \\
\text { fins lucrativos; }\end{array}$ & $\begin{array}{l}\text { Parceria entre } \\
\text { organizações } \\
\text { públicas e } \\
\text { privadas sem fins } \\
\text { lucrativos, cujo } \\
\text { objetivo é propor } \\
\text { melhorias de } \\
\text { eficiência } \\
\text { energética em } \\
\text { edifícios. } \\
\text { Cambridge Energy } \\
\text { Alliance (CEA) }\end{array}$ & $\begin{array}{l}\text { 1.Como os processos } \\
\text { de mudança são } \\
\text { desenvolvidos em } \\
\text { organizações } \\
\text { híbridas? 2.Quais as } \\
\text { influências desses } \\
\text { processos sobre a } \\
\text { combinação de } \\
\text { lógicas institucionais? }\end{array}$ & $\begin{array}{c}\text { Estudo de campo } \\
\text { etnográfico combinado } \\
\text { com elementos de pesquisa } \\
\text { ação. Entrevistas com } \\
\text { executivos e funcionários } \\
\text { da CEA, gestores da } \\
\text { cidade, clientes, parceiros; } \\
\text { registros de arquivos; } \\
\text { observações de reuniões. } \\
\text { Análise: abordagem } \\
\text { iterativa e abdutiva. } \\
\text { codificação do material } \\
\text { coletado. }\end{array}$ & $\begin{array}{l}\text { Resultados de iniciativas de } \\
\text { atores da organização são } \\
\text { interpretados como ambíguos e } \\
\text { paradoxais. Tais resultados são } \\
\text { considerados como um sucesso } \\
\text { pela lógica dos serviços } \\
\text { públicos e um fracasso pela } \\
\text { lógica de negócios de serviços } \\
\text { ao cliente. Este caso da CEA } \\
\text { indica que a combinação de } \\
\text { lógicas pode resultar em } \\
\text { inovação, estagnação ou } \\
\text { oscilaçãa entre as lógicas. }\end{array}$ \\
\hline $\begin{array}{l}\text { Raza-ullah et } \\
\text { al. (2014) }\end{array}$ & $\begin{array}{c}\text { Paradoxo da } \\
\text { coopetição. Busca } \\
\text { simultânea de } \\
\text { cooperação e } \\
\text { competição entre } \\
\text { empresas. }\end{array}$ & $\begin{array}{c}\text { Empresas do } \\
\text { setor de TIC; } \\
\text { fabricantes de } \\
\text { revestimentos } \\
\text { para as usinas } \\
\text { utilizadas na } \\
\text { indústria de } \\
\text { mineração; } \\
\text { fabricantes de } \\
\text { fibra óptica; } \\
\text { fabricantes de } \\
\text { fontes de laser; } \\
\text { CEO's; gerentes } \\
\text { de vários níveis }\end{array}$ & $\begin{array}{c}\text { Empresas } \\
\text { concorrentes: } \\
\text { Sony } v \text { s. Samsung; } \\
\text { Apple } v s . \text { Google; } \\
\text { Skega } v s . \text { Trellex; } \\
\text { Permanova } \\
\text { vs.Rofin Sinar }\end{array}$ & $\begin{array}{l}\text { 1. Quais os principais } \\
\text { fatores contextuais } \\
\text { por trás da } \\
\text { materialização do } \\
\text { paradoxo da } \\
\text { coopetição? 2. Qual a } \\
\text { tensão que surge } \\
\text { como consequência } \\
\text { do paradoxo? } \\
\text { 3. Qual a localização } \\
\text { e a persistência da } \\
\text { tensão do paradoxo? }\end{array}$ & $\begin{array}{l}\text { Entrevistas com CEOs e } \\
\text { gerentes de vários níveis }\end{array}$ & $\begin{array}{l}\text { O paradoxo se materializa } \\
\text { quando ocorre simultaneamente } \\
\text { cooperação entre empresas } \\
\text { concorrentes ou quando há } \\
\text { competição entre empresas } \\
\text { parceiras. Tal fato provoca } \\
\text { emoções positivas e negativas } \\
\text { no processo de avaliação das } \\
\text { consequências realizado pelos } \\
\text { atores destas organizações. Tais } \\
\text { emoções positivas e negativas } \\
\text { são consideradas as bases deste } \\
\text { paradoxo da coopetição. }\end{array}$ \\
\hline $\begin{array}{l}\text { Leonardi et } \\
\text { al. (2010) }\end{array}$ & $\begin{array}{c}\text { Paradoxo da } \\
\text { conectividade. Uma } \\
\text { mesma TIC implantada } \\
\text { para resolver questões } \\
\text { à distância cria uma } \\
\text { expectativa de ligação } \\
\end{array}$ & $\begin{array}{l}\text { Organizações } \\
\text { que adotam } \\
\text { teletrabalho; } \\
\text { funcionários em } \\
\text { regime de } \\
\text { teletrabalho } \\
\end{array}$ & $\begin{array}{l}\text { Empresas que } \\
\text { descentralizam } \\
\text { suas atividades e } \\
\text { adotam o regime } \\
\text { de teletrabalho }\end{array}$ & $\begin{array}{c}\text { 1. Como tais } \\
\text { procedimentos } \\
\text { descentralizados } \\
\text { afetam a capacidade } \\
\text { de os } \\
\text { teletrabalhadores de }\end{array}$ & $\begin{array}{l}\text { Comparação, codificação e } \\
\text { categorização das } \\
\text { entrevistas. }\end{array}$ & $\begin{array}{l}\text { A descentralização das } \\
\text { atividades fornece condições } \\
\text { necessárias para os } \\
\text { teletrabalhadores reduzirem a } \\
\text { percepção de distância do } \\
\text { escritório. Isto permite que os }\end{array}$ \\
\hline
\end{tabular}




\begin{tabular}{|c|c|c|c|c|c|c|}
\hline & $\begin{array}{c}\text { constante. } \\
\text { Funcionários em } \\
\text { situação de teletrabalho } \\
\text { usam a TIC para } \\
\text { diminuir a distância } \\
\text { que sentem dos colegas } \\
\text { de trabalho, ao invés } \\
\text { de aumenta-la. }\end{array}$ & & & $\begin{array}{c}\text { atingirem seus } \\
\text { objetivos? } \\
\text { 3.Como os } \\
\text { teletrabalhadores } \\
\text { usam as TICs para } \\
\text { gerenciar as } \\
\text { percepções de outras } \\
\text { pessoas quanto à } \\
\text { distância do escritório } \\
\text { e, simultaneamente, } \\
\text { atingirem suas metas? }\end{array}$ & & $\begin{array}{l}\text { funcionários administrem suas } \\
\text { preocupações relacionadas à } \\
\text { conclusão de tarefas e à } \\
\text { manutenção de } \\
\text { relacionamentos, buscando } \\
\text { flexibilidade e foco. }\end{array}$ \\
\hline $\begin{array}{l}\text { Mazmanian } \\
\text { et al. (2013) }\end{array}$ & $\begin{array}{c}\text { Paradoxo da } \\
\text { autonomia. } \\
\text { Dispositivos móveis de } \\
\text { e-mail aumentam o } \\
\text { envolvimento com o } \\
\text { trabalho, mas também } \\
\text { reduzem a possiblidade } \\
\text { de desconexão deste } \\
\text { mesmo trabalho }\end{array}$ & $\begin{array}{l}\text { Profissionais da } \\
\text { informação } \\
\text { (indivíduos que } \\
\text { fazem muito uso } \\
\text { de dispositivos } \\
\text { móveis de e-mail } \\
\text { (BlackBerrys) }\end{array}$ & $\begin{array}{c}\text { Profissionais da } \\
\text { informação nos } \\
\text { anos de } 2004 \mathrm{e} \\
2005 . \\
\text { Profissionais } \\
\text { autônomos e } \\
\text { demais } \\
\text { profissionais do } \\
\text { setor financeiro }\end{array}$ & $\begin{array}{l}\text { 1.Como e por que os } \\
\text { profissionais da } \\
\text { informação usam } \\
\text { dispositivos móveis } \\
\text { de e-mail para } \\
\text { restringir e ao mesmo } \\
\text { tempo aumentar sua } \\
\text { autonomia no } \\
\text { exercício de suas } \\
\text { atividades } \\
\text { profissionais e } \\
\text { pessoais? }\end{array}$ & $\begin{array}{c}\text { Codificação e } \\
\text { categorização das } \\
\text { transcrições das entrevistas } \\
\text { Análise: Grounded theory. }\end{array}$ & $\begin{array}{l}\text { O uso de dispositivos móveis } \\
\text { de e-mail oferece aos } \\
\text { profissionais da informação } \\
\text { flexibilidade, tranquilidade e } \\
\text { controle, mas também aumenta } \\
\text { as expectativas em outros } \\
\text { indivíduos em relação à } \\
\text { disponibilidade destes } \\
\text { profissionais. } \\
\text { O paradoxo da autonomia } \\
\text { reflete a tensão entre os } \\
\text { interesses pessoais e } \\
\text { profissionais. }\end{array}$ \\
\hline $\begin{array}{l}\text { Grigore et al. } \\
\quad(2021)\end{array}$ & $\begin{array}{c}\text { Paradoxo da } \\
\text { digitalização. } \\
\text { Tecnologias digitais } \\
\text { facilitam práticas de } \\
\text { trabalho, mas causam } \\
\text { preocupações pessoais }\end{array}$ & Gerentes & $\begin{array}{c}\text { Gerentes de } \\
\text { diversos tipos de } \\
\text { organizações } \\
\text { engajados em } \\
\text { aspectos de ética, } \\
\text { sustentabilidade } \\
\text { ou } \\
\text { responsabilidade } \\
\text { localizados no } \\
\text { Reino Unido } \\
\end{array}$ & $\begin{array}{l}\text { Como gerentes de } \\
\text { responsabilidade } \\
\text { usam a retórica para } \\
\text { construir e resolver os } \\
\text { aparentes paradoxos } \\
\text { relacionados à } \\
\text { tecnologia digital? }\end{array}$ & $\begin{array}{l}\text { Entrevistas gravadas e } \\
\text { transcritas. } \\
\text { Análise: Comparação de } \\
\text { interpretação de dados; } \\
\text { observação de como a } \\
\text { retórica é construída }\end{array}$ & $\begin{array}{l}\text { Tecnologias digitais criam } \\
\text { oportunidades no ambiente de } \\
\text { trabalho mas trazem aspectos } \\
\text { negativos nas vidas pessoais }\end{array}$ \\
\hline $\begin{array}{l}\text { Groscurth } \\
(2011)\end{array}$ & $\begin{array}{c}\text { Privilégio vs. } \\
\text { participação; Inclusão }\end{array}$ & $\begin{array}{l}\text { Organizações } \\
\text { sem fins }\end{array}$ & $\begin{array}{c}\text { Cruz Vermelha } \\
\text { Americana (CVA) }\end{array}$ & $\begin{array}{l}\text { Como os membros da } \\
\text { CVA discursaram em }\end{array}$ & $\begin{array}{l}\text { Estudo de caso único. } \\
\text { Análise de discurso por }\end{array}$ & $\begin{array}{l}\text { As evidências indicaram como } \\
\text { os privilégios são transmitidos }\end{array}$ \\
\hline
\end{tabular}




\begin{tabular}{|c|c|c|c|c|c|c|}
\hline & $\begin{array}{c}v s . \text { exclusão; } \\
\text { Particularidade } v s . \\
\text { universalidade; } \\
\text { Individualidade } v s . \\
\text { identidade } \\
\text { institucional; Privilégio } \\
\text { vs. igualdade. } \\
\text { A imparcialidade } \\
\text { política da Cruz } \\
\text { Vermelha, restringe } \\
\text { inclusão racial e } \\
\text { participação } \\
\text { diversificada }\end{array}$ & $\begin{array}{c}\text { lucrativo; } \\
\text { organizações de } \\
\text { ajuda } \\
\text { humanitária e } \\
\text { demais pessoas } \\
\text { beneficiadas }\end{array}$ & & $\begin{array}{c}\text { questões de } \\
\text { diversidade cultural } \\
\text { após a temporada de } \\
\text { furacões de 2005? }\end{array}$ & $\begin{array}{l}\text { meio de: observações } \\
\text { como membro da CVA; } \\
\text { entrevistas. }\end{array}$ & $\begin{array}{c}\text { por meio de políticas } \\
\text { organizacionais, princípios } \\
\text { orientadores, práticas e ações } \\
\text { discursivas }\end{array}$ \\
\hline $\begin{array}{c}\text { Tye- } \\
\text { Williams \& } \\
\text { Krone (2017) }\end{array}$ & $\begin{array}{l}\text { Paradoxo do conselho. } \\
\text { Utilidade } v s . \\
\text { inutilidade de } \\
\text { aconselhamentos sobre } \\
\text { bullying no trabalho. }\end{array}$ & $\begin{array}{l}\text { Organizações } \\
\text { com casos de } \\
\text { bullying; } \\
\text { Indivíduos que } \\
\text { sofrem bullying } \\
\text { no trabalho; }\end{array}$ & $\begin{array}{l}\text { Empresas com } \\
\text { casos bullying } \\
\text { entre seus } \\
\text { funcionários }\end{array}$ & $\begin{array}{l}\text { 1. Como os alvos do } \\
\text { bullying } \\
\text { experimentam a } \\
\text { utilidade dos } \\
\text { conselhos? } \\
\text { 2. Qual conselho eles } \\
\text { dariam a outras } \\
\text { pessoas que sofrem } \\
\text { bullying? }\end{array}$ & $\begin{array}{l}\text { Entrevistas. Classificação } \\
\text { e comparação dos tipos de } \\
\text { conselhos. Análise } \\
\text { temática dos dados. }\end{array}$ & $\begin{array}{l}\text { Há aspectos favoráveis e inúteis } \\
\text { nos aconselhamentos. A } \\
\text { inutilidade dos conselhos se dá } \\
\text { em razão de não considerarem a } \\
\text { particularidade de cada } \\
\text { indivíduo que sofreu bullying. } \\
\text { Constatou-se ainda que praticar } \\
\text { os aconselhamentos poderia } \\
\text { agravar a situação a ponto de } \\
\text { causar a perda do emprego }\end{array}$ \\
\hline $\begin{array}{c}\text { Van den } \\
\text { Brinck \& } \\
\text { Stobbe } \\
(2019)\end{array}$ & $\begin{array}{c}\text { Paradoxo da } \\
\text { visibilidade. } \\
\text { Preconceito contra o } \\
\text { gênero feminino em } \\
\text { cursos de Earth } \\
\text { Sciences gera um } \\
\text { comportamento de } \\
\text { visibilidade } \\
\text { (desempenho melhor } \\
\text { do que alunos } \\
\text { masculinos) e } \\
\text { invisibilidade (agir e se } \\
\text { vestir como rapazes) } \\
\end{array}$ & $\begin{array}{l}\text { Entidades de } \\
\text { ensino superior; } \\
\text { alunos e demais } \\
\text { membros dessas } \\
\text { entidades }\end{array}$ & $\begin{array}{l}\text { Departamento de } \\
\text { Earth Sciences } \\
\text { (Geologia, } \\
\text { Meteorologia, } \\
\text { Oceanografia e } \\
\text { Astronomia) de } \\
\text { uma universidade } \\
\text { holandesa }\end{array}$ & $\begin{array}{l}\text { 1. As interações em } \\
\text { sala de aula, as } \\
\text { situações de trabalho } \\
\text { de campo influenciam } \\
\text { as escolhas de estudo } \\
\text { das alunas deste tipo } \\
\text { de ciência? }\end{array}$ & $\begin{array}{c}\text { Codificação e } \\
\text { categorização de temas das } \\
\text { notas de campo de } \\
\text { observações e entrevistas } \\
\text { com alunas, ex-alunas e } \\
\text { funcionários (as). Análise } \\
\text { de discurso. }\end{array}$ & $\begin{array}{l}\text { Alunas dedicas obtiveram notas } \\
\text { maiores e terminaram os } \\
\text { estudos antes do que seus } \\
\text { colegas homens. Tal fato, as } \\
\text { torna visíveis, entretanto, havia } \\
\text { uma tendência entre essas } \\
\text { alunas de se vestirem e agirem } \\
\text { como rapazes para se tornarem } \\
\text { invisíveis. Ideia entre os } \\
\text { membros do Departamento } \\
\text { estudado de que as mulheres } \\
\text { não são aptas para este tipo de } \\
\text { ciência. }\end{array}$ \\
\hline
\end{tabular}




\begin{tabular}{|c|c|c|c|c|c|c|}
\hline & $\begin{array}{c}\text { em alunas destes } \\
\text { cursos }\end{array}$ & & & & & \\
\hline $\begin{array}{l}\text { Cuganesan } \\
\text { (2017) }\end{array}$ & $\begin{array}{c}\text { Identidade de } \\
\text { semelhança } v s \text {. } \\
\text { distinção (necessidade } \\
\text { de sentir semelhança e } \\
\text { distinção como } \\
\text { motivações poderosas } \\
\text { e opostas na } \\
\text { construção da } \\
\text { identidade individual) }\end{array}$ & $\begin{array}{l}\text { Gerentes seniores } \\
\text { e funcionários }\end{array}$ & $\begin{array}{l}\text { Força policial } \\
\text { estadual da } \\
\text { Austrália }\end{array}$ & $\begin{array}{l}\text { Como os gerentes } \\
\text { seniores e os } \\
\text { funcionários } \\
\text { negociam o paradoxo } \\
\text { da identidade de } \\
\text { semelhança e } \\
\text { distinção ao longo do } \\
\text { tempo? }\end{array}$ & $\begin{array}{l}\text { Estudo de caso único } \\
\text { longitudinal. Análise } \\
\text { documental. Entrevistas } \\
\text { em vários níveis da } \\
\text { organização. }\end{array}$ & $\begin{array}{l}\text { Identificação de eventos } \\
\text { cíclicos nos processos de } \\
\text { negociação de identidades entre } \\
\text { gerentes e funcionários }\end{array}$ \\
\hline $\begin{array}{l}\text { Cunha et al. } \\
\text { (2018) }\end{array}$ & $\begin{array}{l}\text { Contradições em } \\
\text { identidades } \\
\text { organizacionais; } \\
\text { valores; práticas de } \\
\text { liderança; visão das } \\
\text { funções exercidas; } \\
\text { autorreferências }\end{array}$ & $\begin{array}{c}\text { Gerência e } \\
\text { funcionários de } \\
\text { multinacionais e } \\
\text { demais } \\
\text { organizações que } \\
\text { prestam serviços } \\
\text { de assistência } \\
\text { médica }\end{array}$ & $\begin{array}{c}\text { Empresa } \\
\text { multinacional de } \\
\text { assistência médica } \\
\text { localizada no sul } \\
\text { da Europa }\end{array}$ & $\begin{array}{l}\text { Quais paradoxos são } \\
\text { notados quando uma } \\
\text { organização decide } \\
\text { incentivar seus } \\
\text { funcionários a se } \\
\text { exprimirem? Por que } \\
\text { alguém recusaria um } \\
\text { convite para se } \\
\text { exprimir? }\end{array}$ & $\begin{array}{l}\text { Estudo de caso único. } \\
\text { Anotações de conversas } \\
\text { informais e entrevistas } \\
\text { com os funcionários e } \\
\text { gerentes de nível médio e } \\
\text { superior. }\end{array}$ & $\begin{array}{l}\text { Descoberta de paradoxos } \\
\text { introduzidos pelo processo de } \\
\text { mudança de cultura que } \\
\text { permitiram os funcionários } \\
\text { manifestarem verbalmente. O } \\
\text { programa de mudança cultural } \\
\text { aprimorou a inovação } \\
\text { organizacional e a criatividade } \\
\text { como valores fundamentais }\end{array}$ \\
\hline $\begin{array}{l}\text { Hatch \& } \\
\text { Erhlich } \\
(1993)\end{array}$ & $\begin{array}{l}\text { Paradoxo do controle. } \\
\text { Ocupação simultânea } \\
\text { de posições } \\
\text { antagônicas: guarda vs. } \\
\text { prisioneiro. Gerentes } \\
\text { são "guardas" de seus } \\
\text { subordinados e } \\
\text { "prisioneiros" o nível } \\
\text { executivo da } \\
\text { organização. } \\
\end{array}$ & $\begin{array}{l}\text { Empresas } \\
\text { multinacionais } \\
\text { do setor de TI; } \\
\text { gerentes } \\
\text { seniores; }\end{array}$ & $\begin{array}{c}\text { Multinacional de } \\
\text { TI. }\end{array}$ & $\begin{array}{l}\text { O humor pode indicar } \\
\text { uma linguagem } \\
\text { adequada para a } \\
\text { interpretação de } \\
\text { paradoxo e da } \\
\text { ambiguidade? }\end{array}$ & $\begin{array}{l}\text { Estudo de caso único. } \\
\text { Análise de conteúdo e } \\
\text { codificação de } \\
\text { observações em reuniões. }\end{array}$ & $\begin{array}{l}\text { Humor pode carregar outras } \\
\text { emoções que expressam } \\
\text { paradoxo e ambiguidade. O } \\
\text { humor dos gerentes revelou que } \\
\text { o paradoxo de controle está } \\
\text { implícito nas questões de } \\
\text { segurança enfrentada por eles }\end{array}$ \\
\hline $\begin{array}{l}\text { Jarzabkowski } \\
\text { \& Lê (2017) }\end{array}$ & $\begin{array}{l}\text { Demandas regulatórias } \\
\text { vs. demandas do } \\
\text { mercado. Uma mesma } \\
\text { regulação com o } \\
\text { objetivo de garantir } \\
\end{array}$ & $\begin{array}{c}\text { Gerentes; } \\
\text { empresas de } \\
\text { telecomunicações }\end{array}$ & $\begin{array}{c}\text { Empresa de } \\
\text { telecomunicações } \\
\text { europeia que } \\
\text { passou por grande } \\
\text { reestruturação em } \\
\end{array}$ & $\begin{array}{c}\text { 1. Como o humor } \\
\text { constrói paradoxos no } \\
\text { dia a dia do trabalho? } \\
\text { 2. Como essas } \\
\text { construções } \\
\end{array}$ & $\begin{array}{c}\text { Estudo etnográfico, } \\
\text { longitudinal em tempo } \\
\text { real. A coleta de dados foi } \\
\text { baseada na observação } \\
\text { (notas de campo) de }\end{array}$ & $\begin{array}{l}\text { Paradoxo construído } \\
\text { socialmente pelo humor dos } \\
\text { atores. Tal humor é uma peça } \\
\text { central numa dinâmica de } \\
\text { relações que gera respostas }\end{array}$ \\
\hline
\end{tabular}




\begin{tabular}{|c|c|c|c|c|c|c|}
\hline & $\begin{array}{c}\text { mercado competitivo } \\
\text { se opunha ao } \\
\text { comportamento } \\
\text { competitivo deste } \\
\text { mesmo mercado } \\
\text { as pessoas fazem } \\
\text { muitas piadas sobre } \\
\text { condições paradoxais }\end{array}$ & & $\begin{array}{l}\text { resposta a uma } \\
\text { nova } \\
\text { regulamentação do } \\
\text { governo }\end{array}$ & $\begin{array}{l}\text { determinam as } \\
\text { respostas dos atores } \\
\text { ao paradoxo? }\end{array}$ & $\begin{array}{l}\text { reuniões, entrevistas com } \\
\text { gerentes de vários níveis } \\
\text { da empresa; observação de } \\
\text { tarefas, documentos, } \\
\text { interações, reuniões. }\end{array}$ & $\begin{array}{l}\text { padronizadas consolidadas } \\
\text { (reiteração de um padrão de } \\
\text { resposta existente que aumenta } \\
\text { sua legitimidade da resposta) ou } \\
\text { mutáveis (proposição de uma } \\
\text { resposta alternativa a um } \\
\text { padrão existente). }\end{array}$ \\
\hline $\begin{array}{l}\text { Huq et al. } \\
\text { (2017) }\end{array}$ & $\begin{array}{l}\text { Médicos vs. } \\
\text { Especialistas em } \\
\text { Comportamento } \\
\text { Psicossocial; } \\
\text { medicação vs. } \\
\text { automotivação; }\end{array}$ & $\begin{array}{l}\text { Psiquiatras; } \\
\text { enfermeiros; } \\
\text { assistentes } \\
\text { sociais; gerentes; } \\
\text { secretaria } \\
\text { (autoridade) de } \\
\text { saúde }\end{array}$ & $\begin{array}{c}\text { Secretaria } \\
\text { (autoridade) de } \\
\text { saúde, Canadá }\end{array}$ & $\begin{array}{l}\text { Como profissionais e } \\
\text { gerentes se envolvem } \\
\text { com o paradoxo para } \\
\text { executar atividades } \\
\text { que exigem diferentes } \\
\text { profissões? }\end{array}$ & $\begin{array}{l}\text { Estudo de caso único } \\
\text { Codificação e } \\
\text { categorização de } \\
\text { entrevistas, observações de } \\
\text { reuniões e documentos. }\end{array}$ & $\begin{array}{c}\text { Profissionais e gerentes } \\
\text { evitavam e transformam ciclos } \\
\text { viciosos (tensões negativas) em } \\
\text { ciclos virtuosos (tensões } \\
\text { positivas). Isso foi possível } \\
\text { porque a tensão entre os pólos } \\
\text { do paradoxo era mantida sob } \\
\text { controle (proteção do } \\
\text { paradoxo). Tal processo } \\
\text { proporcionou melhores } \\
\text { resultados para os pacientes. }\end{array}$ \\
\hline $\begin{array}{l}\text { Silva T. et al. } \\
\text { (2014) }\end{array}$ & $\begin{array}{c}\text { Paradoxo do egoísmo } \\
\text { altruísta; paradoxo de } \\
\text { resultados; paradoxo } \\
\text { de conflito; paradoxo } \\
\text { de relacionamentos. } \\
\text { Expectativas } \\
\text { individuais } v s . \\
\text { expectativas coletivas } \\
\text { (equilíbrio de tensões } \\
\text { interesses individuais e } \\
\text { coletivos da equipe) }\end{array}$ & $\begin{array}{l}\text { Equipes de } \\
\text { futebol amador; } \\
\text { jogadores; } \\
\text { treinadores; } \\
\text { diretores }\end{array}$ & $\begin{array}{l}\text { Equipe de futebol } \\
\text { amador português }\end{array}$ & $\begin{array}{l}\text { 1.O significa espírito } \\
\text { de equipe? Onde é } \\
\text { encontrado? Como } \\
\text { mantê-lo? } \\
\text { 2. Tal espírito é uma } \\
\text { propriedade de } \\
\text { equipe? Ele é } \\
\text { depende das } \\
\text { contribuições } \\
\text { individuais dos } \\
\text { membros da equipe? }\end{array}$ & $\begin{array}{c}\text { Estudo de caso único. } \\
\text { Entrevistas } \\
\text { semiestruturadas com } \\
\text { jogadores, treinadores, } \\
\text { diretores; notas de campo } \\
\text { durante os jogos semanais } \\
\text { e demais interações da } \\
\text { equipe. Análise dos dados } \\
\text { por agrupamento } \\
\text { semiótico. }\end{array}$ & $\begin{array}{l}\text { Espírito de equipe é uma } \\
\text { estrutura cognitiva } \\
\text { compartilhada por membros de } \\
\text { um time que sintetizar os } \\
\text { processos sociais contraditórios } \\
\text { inerentes à vida em grupo: } \\
\text { objetivos individuais e } \\
\text { coletivos, vitória e perda, } \\
\text { proximidade e distância de } \\
\text { relacionamentos. } \\
\text { Equilíbrio e combinação dos } \\
\text { objetivos individuais com os } \\
\text { objetivos da equipe permite } \\
\text { uma excelente posição para } \\
\text { organização. }\end{array}$ \\
\hline
\end{tabular}




\begin{tabular}{|c|c|c|c|c|c|c|}
\hline $\begin{array}{l}\text { Gaim et al. } \\
\text { (2019) }\end{array}$ & $\begin{array}{l}\text { Objetivo impossível vs. } \\
\text { Objetivo plausível; } \\
\text { desejo vs. conquista; } \\
\text { ilusão vs. realidade. }\end{array}$ & $\begin{array}{l}\text { Indústria } \\
\text { automobilística; } \\
\text { engenheiros; } \\
\text { clientes, } \\
\text { acionistas; } \\
\text { ambientalistas; } \\
\text { CEO's; }\end{array}$ & $\begin{array}{l}\text { Montadora de } \\
\text { automóveis. }\end{array}$ & $\begin{array}{c}\text { Como uma } \\
\text { organização busca } \\
\text { garantir uma } \\
\text { identidade desejável? }\end{array}$ & $\begin{array}{l}\text { Análise e triangulação de } \\
\text { dados obtidos dos } \\
\text { principais meios de } \\
\text { comunicação, livros, } \\
\text { documentários, audiências } \\
\text { do CEO da empresa e } \\
\text { comunicados da } \\
\text { montadora sobre o tema. }\end{array}$ & $\begin{array}{l}\text { A decisão de um líder em } \\
\text { aceitar o paradoxo acarreta } \\
\text { disfunção entre promessa e } \\
\text { entrega. Além disso, tal decisão } \\
\text { pode desencadear ciclos } \\
\text { viciosos incontroláveis. }\end{array}$ \\
\hline $\begin{array}{c}\text { Jezierska \& } \\
\text { Sörbom } \\
(2020)\end{array}$ & $\begin{array}{c}\text { Paradoxo da } \\
\text { independência: manter } \\
\text { proximidade } \\
\text { (dependência para } \\
\text { exercer influência e } \\
\text { obter financiamento } v s . \\
\text { manter distância } \\
\text { (independência para } \\
\text { obter legitimidade e } \\
\text { autoridade) }\end{array}$ & $\begin{array}{l}\text { CEO's e } \\
\text { diretores de } \\
\text { grupos de } \\
\text { reflexão }\end{array}$ & Polônia e Suécia & $\begin{array}{l}\text { Como os grupos de } \\
\text { reflexão se organizam } \\
\text { e se representam } \\
\text { como independentes.? }\end{array}$ & $\begin{array}{l}\text { Codificação abdutiva e } \\
\text { análise de entrevista e } \\
\text { documentos para } \\
\text { estabelecer padrões em } \\
\text { contextos diferentes. }\end{array}$ & $\begin{array}{l}\text { Necessidade de gerenciar } \\
\text { proximidade e distância para } \\
\text { equilibrar independência e } \\
\text { influência. }\end{array}$ \\
\hline $\begin{array}{c}\text { Lannon \& } \\
\text { Walsh } \\
(2020)\end{array}$ & $\begin{array}{l}\text { Paradoxo da } \\
\text { exploração e } \\
\text { aproveitamento de } \\
\text { conhecimento }\end{array}$ & $\begin{array}{c}\text { Gerentes; } \\
\text { supervisores; } \\
\text { profissionais de } \\
\text { TI }\end{array}$ & $\begin{array}{c}\text { Três países da } \\
\text { África; parcerias } \\
\text { não } \\
\text { governamentais } \\
\text { locais e } \\
\text { internacionais }\end{array}$ & $\begin{array}{l}\text { Como as parcerias } \\
\text { organizacionais } \\
\text { equilibram a } \\
\text { exploração e o } \\
\text { aproveitamento de } \\
\text { conhecimento em } \\
\text { contextos paradoxais? }\end{array}$ & $\begin{array}{l}\text { Estudo de casos múltiplos; } \\
\text { codificação e } \\
\text { categorização de dados } \\
\text { coletados em grupos } \\
\text { focais, entrevistas } \\
\text { semiestruturadas, } \\
\text { observação de práticas de } \\
\text { compartilhamento de } \\
\text { conhecimento (reuniões e } \\
\text { repositórios on line). }\end{array}$ & $\begin{array}{c}\text { Exploração e aproveitamento } \\
\text { do conhecimento existem mais } \\
\text { como dualidade do que como } \\
\text { dualismo. Tal fato tem suporte } \\
\text { na aceitação e embate dos } \\
\text { paradoxos da realização e do } \\
\text { pertencimento. Os resultados } \\
\text { indicam que os paradoxos de } \\
\text { pertencimento e realização não } \\
\text { afetam negativamente a } \\
\text { capacidade das parcerias de } \\
\text { equilibrar a exploração e } \\
\text { aproveitamento do } \\
\text { conhecimento, enquanto os } \\
\text { paradoxos da organização } \\
\text { impedem a capacidade de tal } \\
\text { equilíbrio. }\end{array}$ \\
\hline
\end{tabular}




\begin{tabular}{|c|c|c|c|c|c|c|}
\hline $\begin{array}{l}\text { Lin et al. } \\
(2019)\end{array}$ & $\begin{array}{c}\text { Estabilidade } v s . \\
\text { mudança. Estabilidade } \\
\text { para mudar e mudança } \\
\text { para estabilizar. }\end{array}$ & $\begin{array}{l}\text { CEO's; gerentes; } \\
\text { vendedores, } \\
\text { empregados do } \\
\text { setor de produção }\end{array}$ & $\begin{array}{l}\text { Indústria de LED } \\
\text { da China }\end{array}$ & $\begin{array}{c}\text { Como uma } \\
\text { organização busca a } \\
\text { estabilidade e a } \\
\text { mudança } \\
\text { simultaneamente para } \\
\text { promover o seu } \\
\text { desenvolvimento? }\end{array}$ & $\begin{array}{c}\text { Estudo de caso } \\
\text { exploratório e } \\
\text { interpretativo; } \\
\text { categorização, codificação } \\
\text { e análise de conteúdo das } \\
\text { entrevistas } \\
\text { semiestruturadas, dados de } \\
\text { arquivo e observação. }\end{array}$ & $\begin{array}{c}\text { A estabilidade de processos e } \\
\text { rotinas possibilita a mudança } \\
\text { por meio da segurança, } \\
\text { consistência, conhecimentos e } \\
\text { habilidades exclusivos. A } \\
\text { mudança propicia estabilidade } \\
\text { por meio de mecanismos } \\
\text { variáveis, como atividades de } \\
\text { tentativa e erro e exploração. } \\
\text { Os resultados também indicam } \\
\text { que a mudança organizacional } \\
\text { ajuda uma organização a } \\
\text { alcançar um novo estágio de } \\
\text { estabilidade com maior } \\
\text { eficiência. }\end{array}$ \\
\hline $\begin{array}{l}\text { Pradies et al. } \\
\quad(2020)\end{array}$ & $\begin{array}{l}\text { Conflitos entre } \\
\text { demandas de curto e } \\
\text { longo prazo, mas } \\
\text { interligadas e } \\
\text { agrupadas entre os } \\
\text { escalões }\end{array}$ & $\begin{array}{l}\text { Diretores; } \\
\text { gerentes }\end{array}$ & $\begin{array}{l}\text { Multinacional do } \\
\text { setor energético }\end{array}$ & $\begin{array}{l}\text { Como ocorre uma } \\
\text { mudança do ciclo } \\
\text { vicioso para o } \\
\text { virtuoso? }\end{array}$ & $\begin{array}{l}\text { Pesquisa ação realizada em } \\
\text { três fases: trabalho de } \\
\text { base, ação planejada e } \\
\text { teorização; entrevistas; } \\
\text { documentos e anotações de } \\
\text { observações de reuniões }\end{array}$ & $\begin{array}{l}\text { Identificação três esforços } \\
\text { realizados pelos atores de apoio } \\
\text { para permitir uma mudança } \\
\text { progressiva: (1) romper a } \\
\text { dinâmica disfuncional para } \\
\text { interromper o ciclo vicioso; (2) } \\
\text { facilitar novas respostas para } \\
\text { permitir a reversão do ciclo; e } \\
\text { (3) incorporar dinâmicas } \\
\text { virtuosas na organização }\end{array}$ \\
\hline $\begin{array}{l}\text { Tuckermann } \\
\text { (2018) }\end{array}$ & $\begin{array}{l}\text { Diferenciação (absorve } \\
\text { a complexidade) vs. } \\
\text { integração (reduz a } \\
\text { complexidade; } \\
\text { Saliência e latência de } \\
\text { paradoxos em } \\
\text { interações entre } \\
\text { hospitais e seus } \\
\text { membros } \\
\end{array}$ & $\begin{array}{l}\text { Conselheiros } \\
\text { executivos; } \\
\text { gerentes; } \\
\text { enfermeiros; } \\
\text { médicos }\end{array}$ & $\begin{array}{l}\text { Hospital regional } \\
\text { na Suíça }\end{array}$ & $\begin{array}{l}\text { Como as tensões } \\
\text { contraditórias se } \\
\text { tornam salientes e } \\
\text { latentes durante as } \\
\text { interações inter- } \\
\text { hospitalares, } \\
\text { interprofissionais e } \\
\text { clínica-diretoria? }\end{array}$ & $\begin{array}{c}\text { Estudo de caso único; } \\
\text { análise de observações, } \\
\text { entrevistas } \\
\text { semiestruturadas, arquivos } \\
\text { e workshops; }\end{array}$ & $\begin{array}{l}\text { A latência e a saliência do } \\
\text { paradoxo é um processo } \\
\text { contínuo e endógeno que ocorre } \\
\text { com a ciência dos atores } \\
\text { envolvidos pra que a } \\
\text { organização continue operando. }\end{array}$ \\
\hline
\end{tabular}




\begin{tabular}{|c|c|c|c|c|c|c|}
\hline $\begin{array}{l}\text { Van Helvert- } \\
\text { Beugels et al. } \\
\quad(2020)\end{array}$ & $\begin{array}{c}\text { Tensões: } \\
\text { Profissionalização } \\
\text { (Organização } v s . \\
\text { desorganização), } \\
\text { Colaboração } \\
\text { (autonomia } v s . \\
\text { controle), Alocação de } \\
\text { recursos (foco } \\
\text { organizacional e } \\
\text { comercial } v s . \text { foco } \\
\text { inovador), Transição } \\
\text { de papéis } \\
\text { (distanciamento nas } \\
\text { atividades } v s . \\
\text { permanência nas } \\
\text { atividades) } \\
\end{array}$ & CEO's; gerentes & $\begin{array}{l}\text { Empresa familiar } \\
\text { de porte médio do } \\
\text { ramo de } \\
\text { engenharia } \\
\text { localizada na } \\
\text { Holanda. }\end{array}$ & $\begin{array}{l}\text { 1. Quais tensões } \\
\text { surgem quando a } \\
\text { administração de uma } \\
\text { empresa familiar é } \\
\text { transferida para um } \\
\text { CEO que não é } \\
\text { membro da família? } \\
\text { 2. Como essas } \\
\text { tensões são } \\
\text { gerenciadas? }\end{array}$ & $\begin{array}{l}\text { Pesquisa longitudinal em } \\
\text { tempo real de caso único. } \\
\text { Análise de codificação e } \\
\text { categorização de } \\
\text { observações de reuniões, } \\
\text { conversar casuais e } \\
\text { transcrições de entrevistas } \\
\text { em profundidade. }\end{array}$ & $\begin{array}{l}\text { Identificação de quatro tensões } \\
\text { na transição da administração } \\
\text { da empresa familiar: } \\
\text { profissionalização, colaboração } \\
\text { alocação de recursos, transição } \\
\text { de papéis. Tais tensões são } \\
\text { gerenciadas por mudanças } \\
\text { comportamentais dos principais } \\
\text { envolvidos e de mudanças } \\
\text { estruturais dos sistemas da } \\
\text { empresa. }\end{array}$ \\
\hline $\begin{array}{l}\text { Clark et al. } \\
\text { (2018) }\end{array}$ & $\begin{array}{c}\text { Paradoxo de } \\
\text { desempenho: satisfazer } \\
\text { clientes e os mesmo } \\
\text { tempo ser eficiente } \\
\text { com a quantidade de } \\
\text { chamadas e eficaz na } \\
\text { qualidade dos } \\
\text { resultados. }\end{array}$ & $\begin{array}{l}\text { Atendentes de } \\
\text { call center; } \\
\text { gerentes }\end{array}$ & $\begin{array}{l}\text { Call Center de } \\
\text { uma grande } \\
\text { empresa do setor } \\
\text { financeiro em } \\
\text { Singapura }\end{array}$ & $\begin{array}{l}\text { Como os agentes de } \\
\text { call center resolvem o } \\
\text { paradoxo do } \\
\text { desempenho como } \\
\text { movimentos no } \\
\text { diálogo? }\end{array}$ & $\begin{array}{c}\text { Método misto; } \\
\text { observações das ligações; } \\
\text { transcrição e codificação } \\
\text { em duas etapas das } \\
\text { chamadas telefônicas; } \\
\text { análise de discurso; análise } \\
\text { dimensional e de } \\
\text { configuração das } \\
\text { estratégias adotadas no } \\
\text { atendimento. } \\
\end{array}$ & $\begin{array}{l}\text { O paradoxo é resolvido por } \\
\text { meio de duas estratégias de } \\
\text { construção de solidariedade e } \\
\text { controle de conversa } \\
\text { observadas em } 10 \text { movimentos } \\
\text { de diálogo. }\end{array}$ \\
\hline $\begin{array}{l}\text { Graham et al. } \\
\text { (2016) }\end{array}$ & $\begin{array}{l}\text { Transparência } v s . \\
\text { privacidade }\end{array}$ & $\begin{array}{l}\text { Gestores } \\
\text { públicos; } \\
\text { pesquisadores } \\
\text { universitários }\end{array}$ & $\begin{array}{l}\text { Quatro Estados } \\
\text { dos EUA }\end{array}$ & $\begin{array}{c}\text { Como gestores } \\
\text { públicos gerenciam a } \\
\text { tensão entre } \\
\text { privacidade e } \\
\text { transparência em } \\
\text { relação aos sistemas } \\
\text { integrados de dados } \\
\text { desempenhos } \\
\text { educacionais? }\end{array}$ & $\begin{array}{l}\text { Comparação entre casos; } \\
\text { amostragem intencional; } \\
\text { codificação e análise de } \\
\text { conteúdo de entrevistas } \\
\text { semiestruturadas }\end{array}$ & $\begin{array}{c}\text { Participação dos gestores e } \\
\text { normas conflitantes viabilizam } \\
\text { o compartilhamento de dados; } \\
\text { consultoria jurídica equilibra as } \\
\text { tensões entre transparência e } \\
\text { compartilhamento de dados; } \\
\text { riscos envolvidos afetaram a } \\
\text { escolha da estrutura de acesso } \\
\text { aos dados. } \\
\end{array}$ \\
\hline
\end{tabular}




\begin{tabular}{|c|c|c|c|c|c|c|}
\hline $\begin{array}{l}\text { Wong \& } \\
\text { Jensen } \\
(2020)\end{array}$ & $\begin{array}{l}\text { Paradoxo da confiança: } \\
\text { confiança pública alta } \\
v s \text {. conformidade baixa }\end{array}$ & $\begin{array}{l}\text { Governo central; } \\
\text { cidadãos }\end{array}$ & Singapura & $\begin{array}{l}\text { Como o público } \\
\text { entendeu a gravidade } \\
\text { dos riscos da } \\
\text { pandemia nas } \\
\text { mensagens do } \\
\text { governo? }\end{array}$ & $\begin{array}{l}\text { Análise de conteúdo e } \\
\text { codificação dos dados } \\
\text { obtidos por meio de } \\
\text { rastreamento de mídias } \\
\text { sociais e grupos focais } \\
\text { online }\end{array}$ & $\begin{array}{l}\text { A pandemia da COVID-19 } \\
\text { possibilida que níveis de } \\
\text { confiança pública altos } \\
\text { resultam em níveis menores de } \\
\text { observância das medidas de } \\
\text { gerenciamento de riscos } \\
\text { (subestimação de riscos) por } \\
\text { parte da população. }\end{array}$ \\
\hline
\end{tabular}

Fonte: Elaborado pelo autor 
APÊNDICE C - Levantamento de documentos

O estudo do processo de contratação começou pelo entendimento das fases e estágios, dos documentos gerados e nos seu diversos interessados representados nas figuras 4 e 5 a seguir.

Em seguida foram coletados diversos documentos relacionados às ações de resposta à pandemia nos diversos casos. Os documentos das dispensas de licitações apresentavam dados relacionados às aquisições de insumos e prestações de serviços que podiam ou não ser destinados ao combate da pandemia. A maioria dos outros documentos como decretos, comunicados, boletins e leis indicavam ações de medidas de enfrentamento à pandemia. Apesar de a pesquisa ter coletado outros tipos de documentos que mencionavam a pandemia, a análise deste estudo focou apenas nas dispensas de licitações pois estas foram afetadas diretamente pela pandemia.

Os documentos coletados estão na Tabela 7 “Tipos, Finalidades e Quantidade dos Atos entre (11/03/2020 a 31/12/2020)" a seguir.

A maior parte dos documentos foram coletados nos diários oficiais e portais de transparência dos casos estudados. A Figura 3 é um print de tela que mostra o layout padrão dos portais de transparência dos casos estudados. Tal print destaca o tópico "Licitações e Contratos" e o ícone "Diário Oficial Municipal”. O passar da seta do mouse sobre o tópico "Licitações e Contratos" abre duas opções: "Licitações" e "Contratos". Nestas duas opções eram pesquisadas as dispensas de licitações. O ícone "Diário Oficial Municipal” disponibilizava todos os tipos de publicações oficiais dos municípios. Nestes Diários Oficiais também eram pesquisadas as publicações relacionas às dispensas de licitações e os demais atos que mencionavam a pandemia. Esses dois destaques da Figura 3 expõem que uma mesma informação, no caso as dispensas de licitações, podem ser obtidas em canais diferentes numa única plataforma. 
Figura 3. Fonte de Consulta - Portais de transparência dos casos estudados

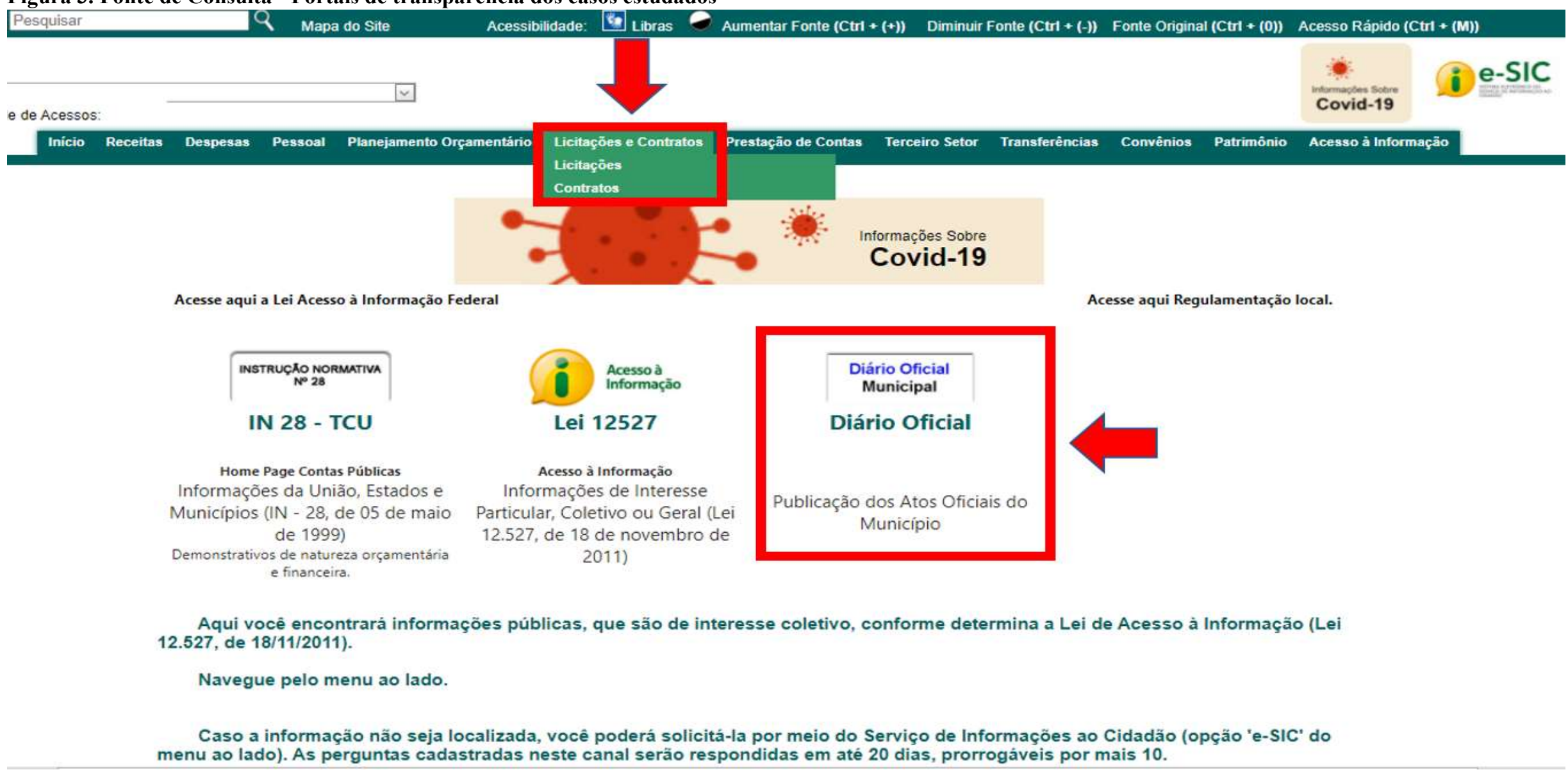

Fonte: Portais de transparência dos casos estudados 


\section{Figura 4. Fases do processo de contratação}

\begin{tabular}{|c|c|c|c|c|c|c|}
\hline $\begin{array}{l}\text { Estágios no } \\
\text { orçamento }\end{array}$ & $\begin{array}{l}\text { Pré-execução } \\
\text { orçamentária }\end{array}$ & \multicolumn{5}{|c|}{ Pré-execução orçamentária (externa ao governo - pública) } \\
\hline $\begin{array}{l}\text { Etapas do } \\
\text { processo }\end{array}$ & Planejamento & Abertura & Habilitação & Julgamento & Adjudicação & Homologação \\
\hline \multirow{4}{*}{$\begin{array}{l}\text { Documentos } \\
\text { Publicação } \\
\text { Exigida } \\
\text { (DPE) }\end{array}$} & \multirow{4}{*}{ - } & a) Resumo do edital & $\begin{array}{l}\text { a) Interposição de } \\
\text { recurso da } \\
\text { habilitação (quando } \\
\text { for o caso) }\end{array}$ & $\begin{array}{l}\text { a) Interposição de } \\
\text { recurso do } \\
\text { julgamento das } \\
\text { propostas (quando } \\
\text { for o caso) }\end{array}$ & - & $\begin{array}{l}\text { a) Interposição da } \\
\text { anulação, ou da } \\
\text { revogação da } \\
\text { licitação (quando for } \\
\text { o caso) }\end{array}$ \\
\hline & & b) Edital & - & - & - & - \\
\hline & & $\begin{array}{l}\text { c) Modificações ao } \\
\text { edital (quando for o } \\
\text { caso) }\end{array}$ & - & - & - & - \\
\hline & & $\begin{array}{l}\text { d) Anulação ou } \\
\text { revogação do edital } \\
\text { (quando for o caso) }\end{array}$ & - & - & - & - \\
\hline \multirow{5}{*}{$\begin{array}{l}\text { Documentos } \\
\text { Publicação } \\
\text { Não Exigida } \\
\text { (DPNE) *** }\end{array}$} & $\begin{array}{l}\text { 1) Três Orçamentos } \\
\text { prévios do objeto } \\
\text { pretendido }\end{array}$ & $\begin{array}{l}\text { 1) Eventual recibo } \\
\text { de retirada do edital }\end{array}$ & - & - & - & $\begin{array}{l}\text { 1) Ata de Sessão } \\
\text { Pública }\end{array}$ \\
\hline & $\begin{array}{l}\text { 2) Consulta para } \\
\text { verificação de } \\
\text { dotação orçamentária }\end{array}$ & $\begin{array}{l}\text { 2)Verificação de } \\
\text { licitantes na Lista de } \\
\text { Apenados do T.C. }\end{array}$ & - & - & - & $\begin{array}{l}\text { 2) Termo de } \\
\text { Homologação }\end{array}$ \\
\hline & $\begin{array}{l}\text { 3) Resposta à } \\
\text { consulta para } \\
\text { verificação de } \\
\text { dotação orçamentária }\end{array}$ & - & - & - & - & $\begin{array}{l}\text { 3) Ato de } \\
\text { Declaração caso } \\
\text { ocorra licitação } \\
\text { deserta, fracassada, } \\
\text { anulada ou revogada }\end{array}$ \\
\hline & 4) Justificativa & - & - & - & - & - \\
\hline & 5) Parecer Jurídico & - & - & - & - & - \\
\hline
\end{tabular}

\begin{tabular}{|l|}
\hline \multicolumn{1}{|c|}{$\begin{array}{c}\text { Execução } \\
\text { orcamentária (fase } \\
\text { contratual) }\end{array}$} \\
\hline Execução do Contrato \\
\hline a) Extrato do contrato \\
\hline $\begin{array}{l}\text { a) Aditamentos } \\
\text { contratuais * }\end{array}$ \\
\hline $\begin{array}{l}\text { b) Rescisão do } \\
\text { contrato* }\end{array}$ \\
\hline $\begin{array}{l}\text { c) Imposição de } \\
\text { penalidade, e resultado } \\
\text { do recurso respectivo* }\end{array}$ \\
\hline 1)Nota de empenho \\
\hline 2) Contrato \\
\hline $\begin{array}{l}\text { 3) Termo de Ciência e } \\
\text { Notificação }\end{array}$ \\
\hline $\begin{array}{l}\text { 4) Declaração de } \\
\text { Documentos à } \\
\text { Disposição do TCE-SP }\end{array}$ \\
\hline 5) Ordem de Serviço* \\
\hline 6) Mensuração \\
\hline 7) Ordem de pgto. \\
\hline 8) Comprovante pgto. \\
\hline
\end{tabular}

Fonte: Elaborada pelo autor

*** Os números dos documentos deste bloco representam a ordem sequencial de elaboração de cada um deles dentro de suas respectivas etapas. * Quando for o caso. 
Figura 5. Interessados nos documentos

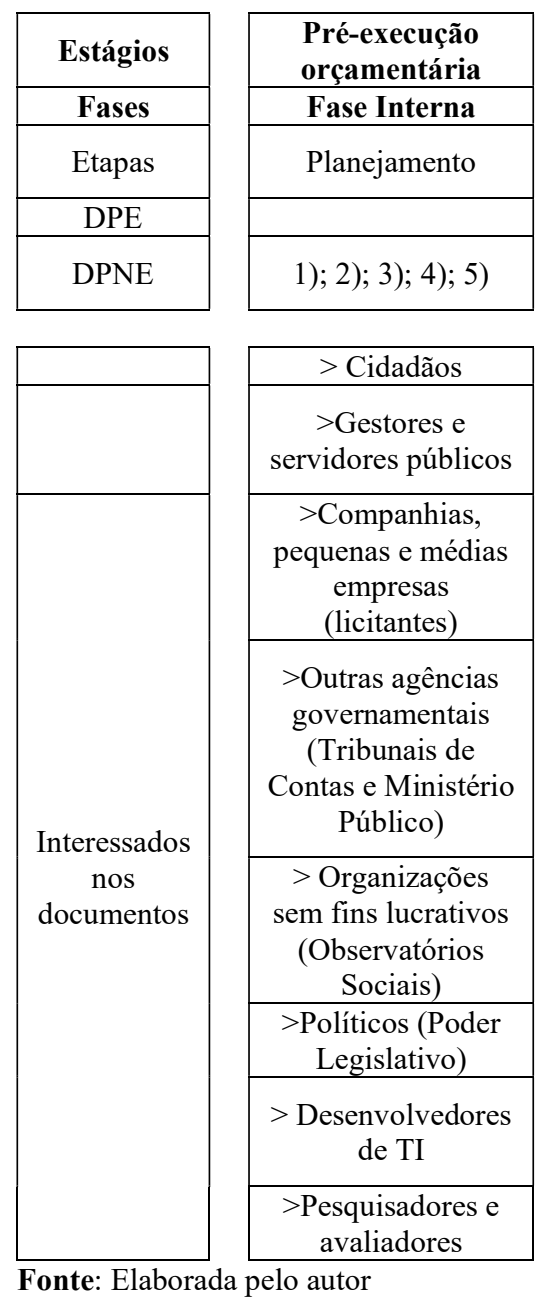

\begin{tabular}{|c|c|c|c|c|}
\hline \multicolumn{5}{|c|}{ Pré-execução orçamentária } \\
\hline \multicolumn{5}{|c|}{ Fase Externa } \\
\hline Abertura & Habilitação & Julgamento & Adjudicação & Homologação \\
\hline a);b);c);d) & a) & a) & & a) \\
\hline 1); 2) & & & & 1);2);3) \\
\hline
\end{tabular}

\begin{tabular}{|c|c|c|c|c|}
\hline$>$ Cidadãos & & & & > Cidadãos \\
\hline $\begin{array}{l}>\text { Gestores e servidores } \\
\text { públicos }\end{array}$ & $\begin{array}{c}>\text { Gestores e } \\
\text { servidores públicos }\end{array}$ & $\begin{array}{l}>\text { Gestores e } \\
\text { servidores } \\
\text { públicos }\end{array}$ & $\begin{array}{c}>\text { Gestores e } \\
\text { servidores públicos }\end{array}$ & $\begin{array}{l}>\text { Gestores e } \\
\text { servidores públicos }\end{array}$ \\
\hline $\begin{array}{c}\text { >Companhias, pequenas } \\
\text { e médias empresas } \\
\text { (licitantes) }\end{array}$ & $\begin{array}{c}>\text { Companhias, } \\
\text { pequenas e médias } \\
\text { empresas (licitantes) }\end{array}$ & $\begin{array}{c}\text { >Companhias, } \\
\text { pequenas e médias } \\
\text { empresas } \\
\text { (licitantes) }\end{array}$ & $\begin{array}{l}\text { >Companhias, } \\
\text { pequenas e médias } \\
\text { empresas (licitantes) }\end{array}$ & $\begin{array}{c}>\text { Companhias, } \\
\text { pequenas e médias } \\
\text { empresas (licitantes) }\end{array}$ \\
\hline $\begin{array}{l}>\text { Outras agências } \\
\text { governamentais } \\
\text { (Tribunais de Contas e } \\
\text { Ministério Público) }\end{array}$ & $\begin{array}{c}\text { >Outras agências } \\
\text { governamentais } \\
\text { (Tribunais de } \\
\text { Contas e Ministério } \\
\text { Público) }\end{array}$ & $\begin{array}{c}>\text { Outras agências } \\
\text { governamentais } \\
\text { (Tribunais de } \\
\text { Contas e } \\
\text { Ministério } \\
\text { Público) }\end{array}$ & $\begin{array}{l}>\text { Outras agências } \\
\text { governamentais } \\
\text { (Tribunais de Contas } \\
\text { e Ministério Público) }\end{array}$ & $\begin{array}{l}\text { >Outras agências } \\
\text { governamentais } \\
\text { (Tribunais de Contas } \\
\text { e Ministério Público) }\end{array}$ \\
\hline $\begin{array}{c}\text { > Organizações sem } \\
\text { fins lucrativos } \\
\text { (Observatórios Sociais) }\end{array}$ & & & & $\begin{array}{c}\text { > Organizações sem } \\
\text { fins lucrativos } \\
\text { (Observatórios } \\
\text { Sociais) }\end{array}$ \\
\hline $\begin{array}{c}>\text { Políticos (Poder } \\
\text { Legislativo) }\end{array}$ & $\begin{array}{c}>\text { Políticos (Poder } \\
\text { Legislativo) }\end{array}$ & $\begin{array}{c}>\text { Políticos (Poder } \\
\text { Legislativo) }\end{array}$ & $\begin{array}{c}>\text { Políticos (Poder } \\
\text { Legislativo) }\end{array}$ & $\begin{array}{c}>\text { Políticos (Poder } \\
\text { Legislativo) }\end{array}$ \\
\hline $\begin{array}{c}>\text { Desenvolvedores de } \\
\text { TI }\end{array}$ & $\begin{array}{c}>\text { Desenvolvedores } \\
\text { de TI }\end{array}$ & $\begin{array}{c}> \\
\text { Desenvolvedores } \\
\text { de TI }\end{array}$ & $\begin{array}{c}>\text { Desenvolvedores de } \\
\text { TI }\end{array}$ & $\begin{array}{c}>\text { Desenvolvedores de } \\
\text { TI }\end{array}$ \\
\hline $\begin{array}{c}>\text { Pesquisadores e } \\
\text { avaliadores }\end{array}$ & & & & $\begin{array}{c}>\text { Pesquisadores e } \\
\text { avaliadores }\end{array}$ \\
\hline
\end{tabular}

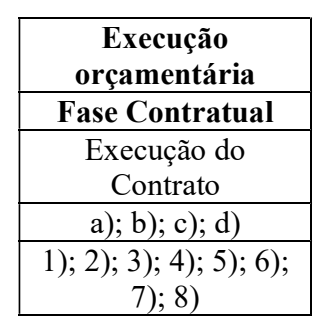

\begin{tabular}{|c|}
\hline$>$ Cidadãos \\
\hline $\begin{array}{c}>\text { Gestores e } \\
\text { servidores públicos }\end{array}$ \\
\hline $\begin{array}{c}>\text { Companhias, } \\
\text { pequenas e médias } \\
\text { empresas } \\
\text { (licitantes) }\end{array}$ \\
\hline $\begin{array}{l}\text { >Outras agências } \\
\text { governamentais } \\
\text { (Tribunais de } \\
\text { Contas e Ministério } \\
\text { Público) }\end{array}$ \\
\hline $\begin{array}{c}>\text { Organizações sem } \\
\text { fins lucrativos } \\
\text { (Observatórios } \\
\text { Sociais) }\end{array}$ \\
\hline $\begin{array}{c}>\text { Políticos (Poder } \\
\text { Legislativo) }\end{array}$ \\
\hline $\begin{array}{c}\text { > Desenvolvedores } \\
\text { de TI }\end{array}$ \\
\hline $\begin{array}{c}>\text { Pesquisadores e } \\
\text { avaliadores }\end{array}$ \\
\hline
\end{tabular}


Tabela 7. Tipos, Finalidades e Quantidade dos Atos entre (11/03/2020 a 31/12/2020 - início e decorrer da pandemia até o final de 2020)

\begin{tabular}{|c|c|c|c|}
\hline Origem do ato & Tipo do Ato & Finalidades dos Atos & $\begin{array}{c}\text { Quantidade dos } \\
\text { Atos }\end{array}$ \\
\hline $\begin{array}{l}\text { Executivo } \\
\text { municipal }\end{array}$ & Dispensa de licitação & Contratar serviços & 477 \\
\hline $\begin{array}{l}\text { Executivo } \\
\text { municipal }\end{array}$ & Dispensa de licitação & Contratar serviços - associados a pandemia & 53 \\
\hline $\begin{array}{l}\text { Executivo } \\
\text { municipal }\end{array}$ & Dispensa de licitação & Adquirir materiais & 327 \\
\hline $\begin{array}{l}\text { Executivo } \\
\text { municipal }\end{array}$ & Dispensa de licitação & Adquirir materiais - associados à pandemia & 227 \\
\hline \multirow[t]{2}{*}{$\begin{array}{l}\text { Executivo } \\
\text { municipal }\end{array}$} & Dispensa de licitação & $\begin{array}{l}\text { Aluguel e alienação de imóveis. Locações dos imóveis eram destinadas a atender pessoas em } \\
\text { situação vulnerável; funcionamento de setores e programas sociais das prefeituras. Obs: Apenas } \\
\text { uma dispensa foi destinada a abrigar pessoas em situação vulnerável para evitar disseminação } \\
\text { da covid-19. }\end{array}$ & 25 \\
\hline & & TOTAL de dispensas de licitação & 1.109 \\
\hline $\begin{array}{l}\text { Executivo } \\
\text { municipal }\end{array}$ & $\begin{array}{c}\text { Interrupção de licitação ou } \\
\text { contrato }\end{array}$ & Adotar medidas de combate à pandemia; Interromper contratações & 22 \\
\hline \multirow[t]{2}{*}{$\begin{array}{l}\text { Executivo } \\
\text { municipal }\end{array}$} & Reabertura de licitação & Adotar medidas de combate à pandemia; retomar contratações & 2 \\
\hline & & TOTAL de atos de contratação & $1.133 ?$ \\
\hline $\begin{array}{l}\text { Executivo } \\
\text { municipal }\end{array}$ & Decretos de emergência & $\begin{array}{l}\text { Decretar situação de emergência; Adotar medidas de isolamento: suspensão de aulas e demais } \\
\text { atividades que propiciam aglomeração de pessoas; adoção de trabalho remoto ou afastamento } \\
\text { para servidores do grupo de risco; redução de expediente de repartições públicas; } \\
\text { recomendação para uso de máscaras }\end{array}$ & 26 \\
\hline $\begin{array}{l}\text { Executivo } \\
\text { municipal }\end{array}$ & Decretos de calamidade & $\begin{array}{l}\text { Decretar situação de calamidade; Adotar medidas de isolamento: suspensão de aulas e demais } \\
\text { atividades que propiciam aglomeração de pessoas; adoção de trabalho remoto ou afastamento } \\
\text { para servidores do grupo de risco; redução de expediente de repartições públicas; } \\
\text { recomendação para uso de máscaras }\end{array}$ & 24 \\
\hline $\begin{array}{l}\text { Executivo } \\
\text { municipal }\end{array}$ & $\begin{array}{l}\text { Decretos, Resoluções, Portarias } \\
\text { de enfrentamento à pandemia }\end{array}$ & $\begin{array}{l}\text { Adotar medidas de isolamento: suspensão de aulas e demais atividades que propiciam } \\
\text { aglomeração de pessoas; adoção de trabalho remoto ou afastamento para servidores do grupo } \\
\text { de risco; redução de expediente de repartições públicas; recomendação para uso de máscaras }\end{array}$ & 913 \\
\hline $\begin{array}{l}\text { Executivo } \\
\text { municipal }\end{array}$ & Convênios & Adotar medidas de combate à pandemia & 8 \\
\hline
\end{tabular}




\begin{tabular}{|c|c|c|c|}
\hline $\begin{array}{l}\text { Executivo } \\
\text { municipal }\end{array}$ & $\begin{array}{l}\text { Deliberação comitê de combate } \\
\text { à pandemia }\end{array}$ & Adotar medidas de combate à pandemia & 5 \\
\hline $\begin{array}{l}\text { Conselho } \\
\text { Municipal }\end{array}$ & $\begin{array}{l}\text { Deliberação de Conselhos } \\
\text { Municipais }\end{array}$ & Adotar medidas de combate à pandemia & 17 \\
\hline $\begin{array}{l}\text { Executivo } \\
\text { municipal }\end{array}$ & $\begin{array}{c}\text { Comunicados de combate à } \\
\text { pandemia }\end{array}$ & Adotar medidas de combate à pandemia & 25 \\
\hline $\begin{array}{l}\text { Executivo } \\
\text { municipal }\end{array}$ & $\begin{array}{l}\text { Dispensa de chamamento } \\
\text { público para parcerias }\end{array}$ & Parcerias com entidades sem fins lucrativos & 3 \\
\hline $\begin{array}{l}\text { Executivo } \\
\text { municipal }\end{array}$ & Termo de fomento & Adotar medidas de combate à pandemia & 4 \\
\hline $\begin{array}{l}\text { Executivo } \\
\text { municipal }\end{array}$ & $\begin{array}{l}\text { Ata comitê de crise e combate } \\
\text { à pandemia }\end{array}$ & Flexibilizar obrigações tributárias e/ou acessórias; Adotar medidas de combate à pandemia & 2 \\
\hline $\begin{array}{l}\text { Executivo } \\
\text { municipal }\end{array}$ & $\begin{array}{c}\begin{array}{c}\text { Edital flexibilização obrigações } \\
\text { tributárias }\end{array} \\
\end{array}$ & Flexibilizar obrigações tributárias e/ou acessórias; Adotar medidas de combate à pandemia & 5 \\
\hline $\begin{array}{l}\text { Executivo } \\
\text { municipal }\end{array}$ & Edital de convocação & $\begin{array}{l}\text { Convocar classificados em concurso público; atribuição de aulas; adotar medidas de combate à } \\
\text { pandemia }\end{array}$ & 3 \\
\hline $\begin{array}{l}\text { Executivo } \\
\text { municipal }\end{array}$ & Processos seletivos de pessoal & Seleção de servidores temporários; adotar medidas de combate à pandemia & 5 \\
\hline $\begin{array}{l}\text { Executivo } \\
\text { municipal }\end{array}$ & Boletim Covid-19 & Informar quadro com número de casos de contaminação locais & 318 \\
\hline $\begin{array}{c}\text { Legislativo } \\
\text { municipal }\end{array}$ & Lei & $\begin{array}{l}\text { Apoiar financeiramente hospitais ou associações locais; Regulamentar distribuição de } \\
\text { alimentos para alunos da rede municipal de ensino }\end{array}$ & 58 \\
\hline \multirow[t]{2}{*}{$\begin{array}{l}\text { Ministério } \\
\text { Público do } \\
\text { Estado de São } \\
\quad \text { Paulo }\end{array}$} & $\begin{array}{c}\text { Recomendação administrativa } \\
\text { - Ministério Público }\end{array}$ & $\begin{array}{l}\text { Alertar quanto ao atendimento de normas: Lei no }{ }^{\circ} 9504 / 97-\text { Lei das Eleições (atenção quanto às } \\
\text { doações bens, valores e benefícios em ano eleitoral); Lei 13.979/2020-Lei do Combate à } \\
\text { Pandemia (atenção quanto à transparência e às formas de contratação). Adotar medidas de } \\
\text { combate à pandemia: indicação para fornecimento adequado de itens de higiene aos Conselhos } \\
\text { Tutelares; indicação para flexibilizar o atendimento dos Conselhos Tutelares }\end{array}$ & 5 \\
\hline & & TOTAL de outros atos & 1.421 \\
\hline
\end{tabular}

Fonte: Elaborado pelo autor 
APÊNDICE D - Descrição da base de atos de contratação

- A pesquisa coletou 1528 atos associados à contratação nos 32 municípios em análise. A coleta foi feita em 9 períodos distintos, sendo que cada período corresponde à uma quinzena de um mês que os documentos foram coletados. A coleta era feita à medida que a pandemia transcorria. Exemplo, no $1^{\mathrm{o}}$ período $\left(2^{\mathrm{a}}\right.$ quinzena de março de 2020) foram coletados documentos de março a dezembro de 2019 e março de $2020,8^{\circ}$ período ( $2^{\mathrm{a}}$ quinzena de janeiro 2021) foram coletados documentos de julho a dezembro de 2020. A pesquisa coletou menos documentos no $4^{\circ}$ período em razão da indisponibilidade de tempo para realizar a coleta ( $1^{\text {a }}$ quinzena maio de 2020$)$ (Tabela 8$)$.

- A cada registro foi anotado o dia de observação e coleta nos sites. A observação e a coleta ocorreram entre março 2020 e fevereiro de 2021. A data de cada ato é referente a data registrada no diário oficial ou no portal da transparência dos municípios analisados.

Tabela 8. Dispensas de licitação identificados 2020-2021

\begin{tabular}{|c|c|c|c|}
\hline Período & Janela de coleta & $\begin{array}{c}\text { Quantidade de dispensas de } \\
\text { licitação }\end{array}$ & $\begin{array}{c}\text { * Dispensas com divulgação } \\
\text { completa em pdf }\end{array}$ \\
\hline 1 & $2^{\mathrm{a}}$ quinzena $03 / 2020$ & 444 & $20,27 \%$ \\
\hline 2 & $1^{\mathrm{a}}$ quinzena $04 / 2020$ & 38 & $21,05 \%$ \\
\hline 3 & $2^{a}$ quinzena $04 / 2020$ & 68 & $22,06 \%$ \\
\hline 4 & $1^{\mathrm{a}}$ quinzena $05 / 2020$ & 2 & 0 \\
\hline 5 & $1^{\mathrm{a}}$ quinzena $07 / 2020$ & 158 & $08,23 \%$ \\
\hline 6 & $2^{\mathrm{a}}$ quinzena $07 / 2020$ & 183 & $12,02 \%$ \\
\hline 7 & $1^{\mathrm{a}}$ quinzena $01 / 2021$ & 145 & $30,34 \%$ \\
\hline 8 & $2^{\mathrm{a}}$ quinzena $01 / 2021$ & 325 & $00,04 \%$ \\
\hline 9 & $1^{\mathrm{a}}$ quinzena $02 / 2021$ & 165 & $28,48 \%$ \\
\hline Total & & 1528 & $16,62 \%$ \\
\hline
\end{tabular}

Fonte: Elaborada pelo autor

Nota: * Divulgação completa: dispensas de licitações com contratos disponibilizados em formato pdf.

- Entre estes documentos estão os atos que efetivamente realizaram contratações por meio das dispensas de licitação. Não foram considerados os 22 atos de interrupção de licitação e contratos. A pesquisa considerou para fins de análise apenas as 1528 dispensas de licitação independentemente se foram ou não 
canceladas ou interrompidas posteriormente, pois isso não impede que parte dos documentos sejam publicados.

- A pesquisa adotou a data de 1 de março como corte entre antes e depois do início da pandemia. Apesar de em 28 fevereiro já ter casos no Brasil, nos primeiros dias de março é que o assunto ganha relevância, e o governo federal anuncia medidas. Em 11/03/2020 a OMS declarou que o mundo estava em pandemia da Covid-19.

- De todos os atos coletados com data posterior a 1 de março 2020, foi observado se o ato mencionava a palavra Covid-19 ou pandemia, pois era uma obrigação legal imposta pela Lei Complementar $n^{\circ} 173$ de 27 de maio de 2020 que estabelece o Programa Federativo de Enfrentamento ao Coronavírus SARS-CoV-2 (Covid19).

- A tabela a seguir (Tabela 9), mostra os atos divididos em 3 grupos: antes da pandemia e durante a pandemia mencionando e não mencionando Covid-19. E a média em que os atos eram divulgados em diversas partes do portal.

Tabela 9. Média de divulgação das dispensas de licitações por canal, antes e durante a pandemia

\begin{tabular}{l|l|l|l|l|l}
\hline & Qtde. & $\begin{array}{l}\text { No portal de } \\
\text { transparência }\end{array}$ & $\begin{array}{c}\text { No portal de } \\
\text { licitações }\end{array}$ & $\begin{array}{c}\text { No portal de } \\
\text { contratos }\end{array}$ & $\begin{array}{c}\text { Em pdf } \\
\text { completo }\end{array}$ \\
\hline $\begin{array}{l}\text { Antes da pandemia } \\
\text { Objeto: Outros }\end{array}$ & 419 & .9976134 & .6038186 & .5131265 & .2171838 \\
\hline $\begin{array}{l}\text { Durante a pandemia } \\
\text { Objeto: Outros }\end{array}$ & 829 & .9083233 & .7418577 & .4185766 & .1761158 \\
\hline $\begin{array}{l}\text { Durante a pandemia } \\
\text { Objeto: Covid-19 }\end{array}$ & 280 & .9821429 & .8964286 & .3214286 & .0607143 \\
\hline Total & 1528 & .9463351 & .7323298 & .4267016 & .1662304 \\
\hline
\end{tabular}

Fonte: Elaborada pelo autor

O diário oficial poderia ser localizado tanto no site oficial do município quanto no portal da transparência. Nos diários oficiais eram publicadas as ratificações das dispensas de licitações e/ou os extratos dos seus respectivos contratos. Os tópicos "Licitações" e "Contratos" eram encontrados dentro do portal da transparência. Nestes dois tópicos alguns municípios disponibilizam os contratos na íntegra de algumas dispensas de licitações. Importante destacar que em alguns casos, uma mesma dispensa era encontrada nos três locais diferentes citados acima. É possível entender que ao não mencionar Covid-19 ou pandemia, as dispensas se direcionavam a outras contratações. A questão é se as políticas de dispensa e transparência se aplicariam também a essas outras contratações. 